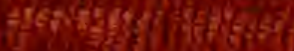

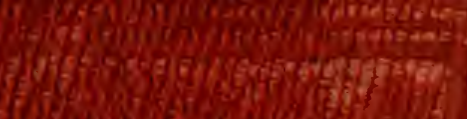

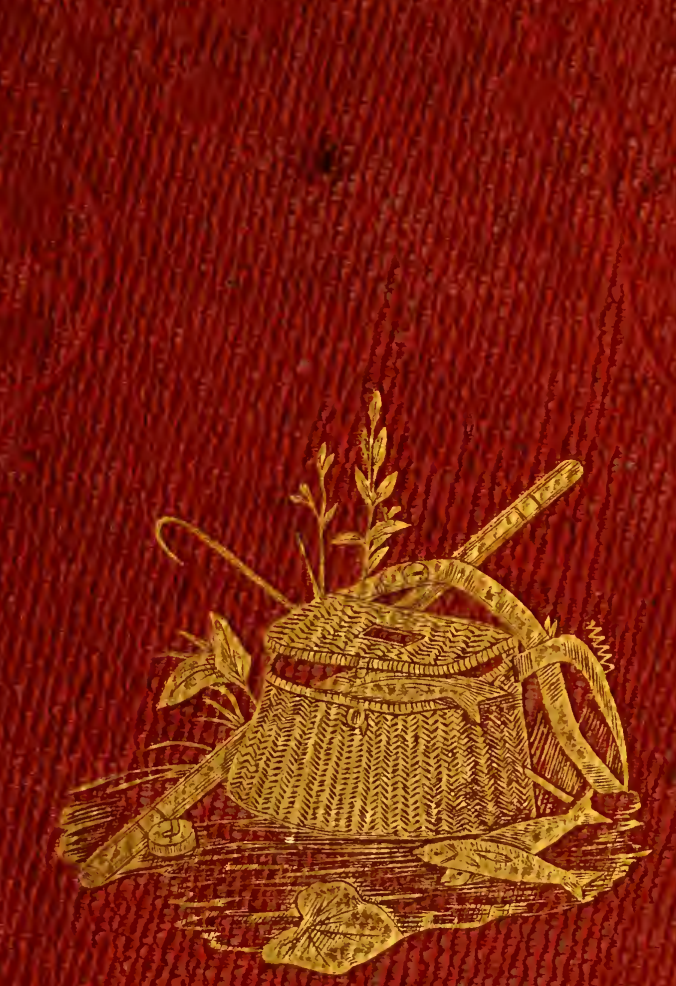

+8:

b)

isfoffys

(f) 1 (I)

(1) 1 (3)

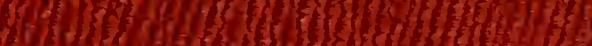

by Whis

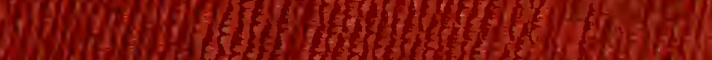

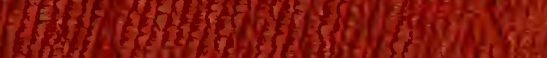

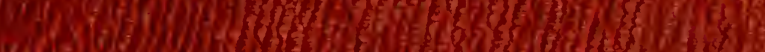
Whathof

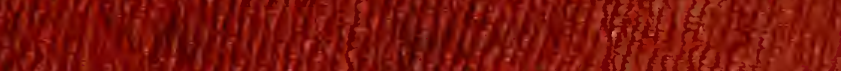
ifin

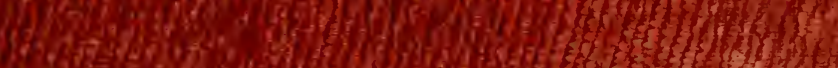
7wa

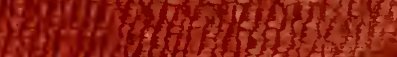




\section{HARVARD UNIVERSITY.}

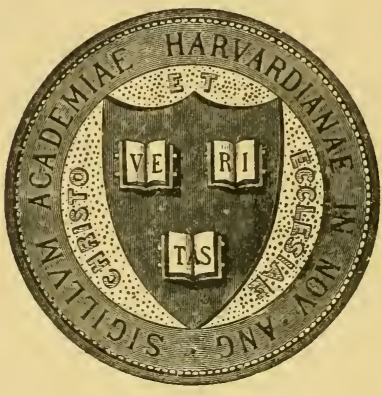

\section{I B R A R Y}

\section{OF THE}

MUSEUM OF COMPARATIVE ZOÖLOGY 28,380

GIFT OF

$$
\text { Charles H. Faylor }
$$

7 ebruary 20,1936 
FEB 201936 



\section{T H E}

\section{B 0 RDER A NGLER.}




$$
\begin{aligned}
& 3196010
\end{aligned}
$$

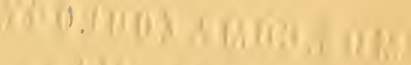

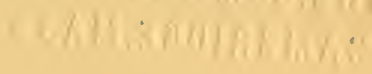




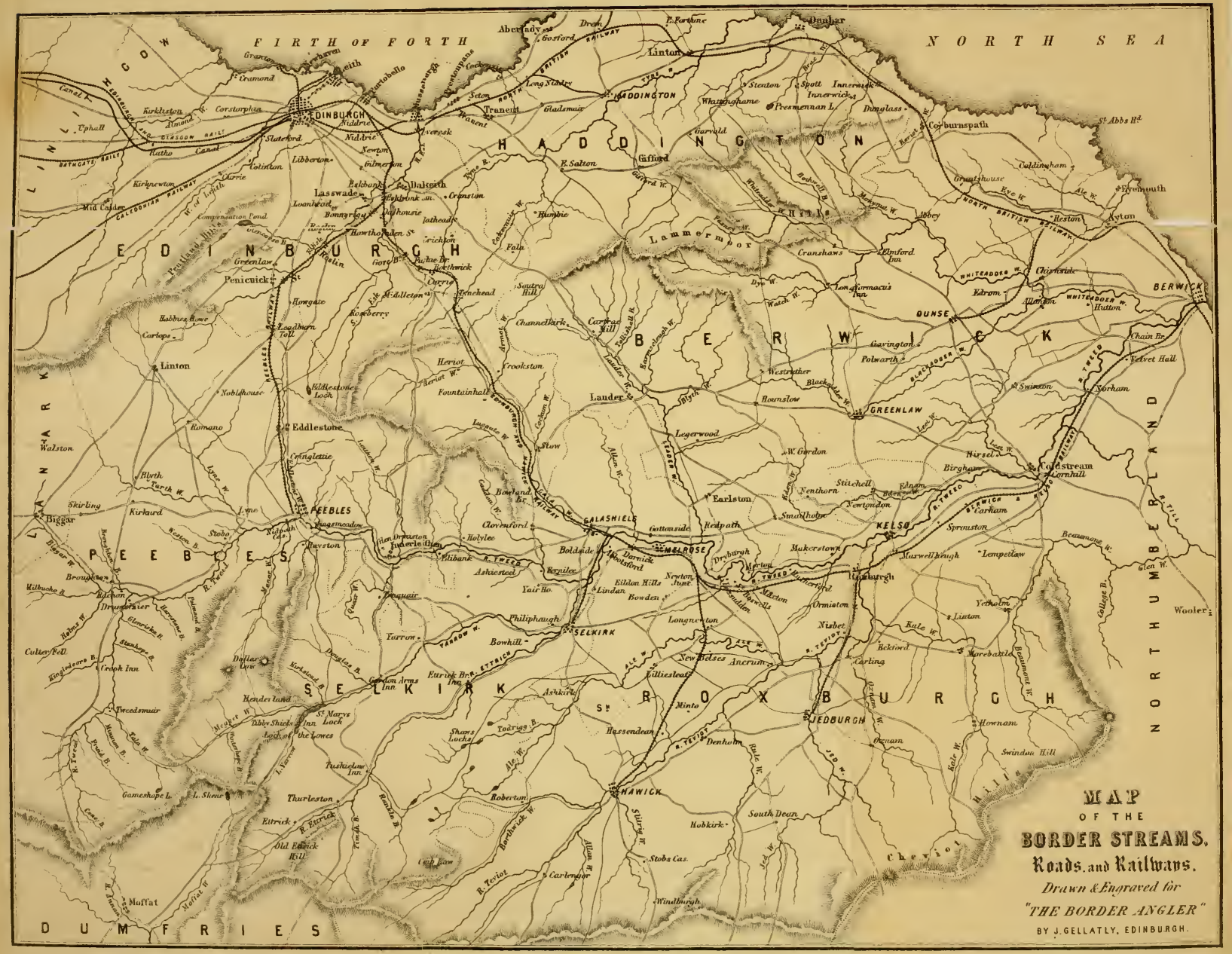





\section{THE \\ BORDER ANGLER:}

A GUIDE-BOOK TO

\section{THE TWEED AND ITS TRIBUTARIES}

AND THE OTHER STREAMS

COMMANDED BY

\section{THE NORTH BRITISH RAILWAY.}

WITH

AN ACCURATE MAP OF THE DISTRICT.

\section{EDINBURGH :}

WILLIAM P. NIMIMO, 2 SOUTH ST. DAVID STREET. LONDON : W. KENT \& Co., PATERNOSTER ROW.

\section{8.}


Let ither angler's choose their ain, And ither waters tak the lead;

$O$ 'Hielan' streams we covet nane, But gie to us the bonuie Tweed ? And gie to us the cheerfu' burn

That steals into its valley fair ; he streamlets that at ilka turn Sae saftly meet and mingle there.

The lanesome Tala and the Lyne, And Manor wi' its mountain rills, And Etterick, whose waters twine WVi' Yarrow frae the forest hills; And Gala too, and Teviot bright, And mony a stream o' playfu' speed; Their kindred valleys a' unite Amang the braes o' bonnie Tweed.

O the Tweed! the bonnie Tweed : $O$ ' rivers it's the best Angle here or angle there, Troots are soomin' ilka where, Angle east or west.

THOMAS TOD STODDART. 


\section{O N T E N T S.}

CHAPTER I. INTRODUCTORY, . . . . . . 1-t

The Angler's location, page 1...Farourable position of Edinburgh, 2...Fraternization of the North British Railway with the Border Streams, 3...The Author's plan, 3.

CHAPTER II. ANGLING ON THE BORDERS, • 5-44

Meatæ, Romans, Monks, and Kelts, 5...Salmon-fishing, 7 ...Rapid decrease of the fish and of the Rentals of the Fishings, 9...The Tweed Fisheries Acts, 10-13... Extent of kelt-killing in the Tweed, 15... Rod-fishing for Salmon with fly, worm, parr-tail, \&c. 16-23...The habits of the Salmon, 19...His freaks when hooked, 24...Trout-fishing, 25...Fly, worm, creeper, and Mayfly, 26-37...Stewart's new methods, 27,35 ... Minnow and Roe-fishing, 38, 40...Forbidden fish, 43 .

CHAPTER III. THE TWEED, - . . . . . $\$ 5-96$

Character of the River from source to mouth, 45...Mr. Stoddart's eulogium, 46...The Crook, 49...Hill-burns, 50 ...The Tala and the upper Tributaries, 51...Biggarwater, Rachan Mill, and Broughton, 52, 53...The Lyne and the Tarth, 55...PEebles and its neighbourhood, 56...Manor-water, 57...Eddleston-water, 58... The Peebles Anglers, 59...Innerleithen, 59...The Leithen and the Quair, 60, 61..." The Bush aboon Traquair," $6 \mathbf{i} . .$. Ashestiel and neighbourhood, $62 .$. Tweed Trout-flies, 63...Caddon-wate and Clovenford, 64... 
Salmon-fishing..." The Nest," 61... Scott at Ashestiel, 65...A night's Leistering with the Ettrick Shepherd ...the ducking in Gliddy's Weal, 66...Sir Walter at Abbotsford...the coursing-match on Newark Hill, 67 ...Scott's last home coming, $69,70 \ldots$ His death, $70 \ldots$ Allan-water...Lord Somerrille's Fishings, 71...The Law of Trout-fisling, 72, 75...MELROSE, 72-74...Dryburgh...St. Boswell's...John Younger, 76-79...Rutherford-water, 80 ...Ducal restrictions on Trout-fishing, and imitations thereof by smaller fry, $82,83 \ldots$ Makerston Trows....Rob Kerss, 83...Floors....KELso, 85... Forrest's rods and flies, 86 ...Sprouston Dub, 87 ...The Eden...Birgham-water, 88...Coldstream, 89...The Leet, 90...The Till, the Bowmont, and the Glen, 91....Millfield Plain...Tweedmill, 93...St. Cuthbert...Tillmouth Castle, 94... Norham Castle... Salmon traps, 95.

\section{CHAPTER IV. ETTRICK AND YARROW, .}

The Forest, 97...Salmon and Trout-poaching, 99...Lord Minto's Act, 100...Head of the Ettrick, 101...Timah ....Rankleburn....Tuslilaw, 102....Traditions of the Forest, 103...The Ettrick Shepherd, 104...His astonishing draught of fislues in the Meggat, 115, note...Boston's "Fourfold State," 105... The Ettrick, from Tushilaw down wards, 10.j...St. Mary's Loch, 106...Tibbie Shiels ...her distinguished guests, and kindly care of them, 107 ...Hints on Juch-fisling, 109...Pike-fisling, $110 \ldots$ Perch-fishing, 114... Little Yarrow...The Meggat, 114, $115 . .$. Loch Skene, 116....Roads to St. Mary's, 117.... Scenes of old Ballads, 118-20...Loch of the Lowes, 119 ... Dryliope Tower... The Yarrow, 121...Newark Castle...Bowlill, 122...Experiments in breeding Salmon, 122 , note... Selkirk...Disputed dram at the battle of Philiphaugh, 124.

\section{CHAPTER V. THE GALA AND THE LEADER,}

Edinburgh fishers and fast-days, 125 ...The trout amazed at the multitudinous invasion, 126 ... Vast numbers annually caught in the Gala, ib...Heriot-water, 127 ... Large Trout near Stow, 129...The Luggate...Galashiels Poachers, 130 ....Factory pollutions, 131....The 
Vale of Gala, ib...The Leader and its Fceders, 132... Our " old Nobilitie," 135....James Baillie of Lauder, 136...Carrolside-water...Earlston, 137...Thomas the Rlyymer..." The Broom of the Cowdenknowes," $138 . .$. Sandyknowe...Smailholm Tower, 139.

CHAP. VI. THE TEVIOT AND ITS TRIBUTARIES, 140-58

Drinking and fishing in the olden times, 141...Source of the Teviot, 142...The Allan...Borthwick-water... Branxholm Castle, 143...Hawick...The Slitrig...Stobbs Castle, 114....Minto Castle....Hawick Netters....The Rule...Denholm...John Leyden, 145...The Ale...John Younger again, 148-50...Ancrum Moor...The Jed, 150 The poet Thomson, and his angling sketch in "The Seasons," $151 . .$. Fishing among trees, 152...J EDBURGH ....its antiquity....The Oxnam and the Kale, 154... Heaton-mill cauld...Mr. Purves's kelt-killing, 155... Mr. Stoddart's monster Eel, 156...Pike and Perch in the Teviot, 158.

CHAP. VII. THE WHITADDER \& BLACKADDER, 159-80

These Berwickshire Twins unlike each other, 159...Head of the Wlitadder, ib...The Fasney a stream in a state of nature, 160...I Icather Trout, 161...Cranshaws, 162 ... Botliwell-burn...Dye-water ... Watch-water, 163... Blacksmill-burn....Burn-fisling with dipping minnow, 16t...Longformacus...Ellemford...Geordie Hamilton, 165...Geordie's angling feats...lis migrations ...his r'ule of " chairge," 166-7....Fishing-inn charges ...decline of toddy-drinking, 167-68....Hints on refreshing, 169...Abbey St. Bathan's...Dunse, 172...The Covenanters on Dunse Law...Chirnside, 173...David Hume at Ninewells...Allanton, 174...The Blackadder ...The Legend of Twinlaw-Cairns, 175...Straightening of water-courses, 176 .... Greenlaw....The protectionist system on the Blackadder, 177....Lower part of the Whitadder, 178...The Anacharis Alsinastrum, 179.

CHAP. VIII. THE EYE, THE TYNE, THE ESKS, 181-91

The Eye, Grant's House, Reston, Ayton, 181-2...The Tyne, its upper waters, 183...Haddingtor...rigid pre- 
servation of the river, 184...The valley of the Tyne... Crichton Castle....Hailes Castle...Tyningham...Pressmennan Loch...Biel Burn, 184-5....The Esks....The Duke of Buccleuch and the Edinburgh Commisioners of Supply on the pollution of the North Esk, 185-7 ...The South Esk...Upper portion of the North Esk, 188.....Glencorse-burn....The Compensation Pond.... Edinburgh Pic-nic-ers...Habbie's Howe, 189....Mouth of the Esk...Sea-trout...the Scenery, 190-1.

CONCLUSION, .

The Anatomist of Melancholy on Fishing, 192...The Philosoplyy of the Sport, 193...The need of earnestness, 194...Izaak Walton's pious conclusion, 19.5. 


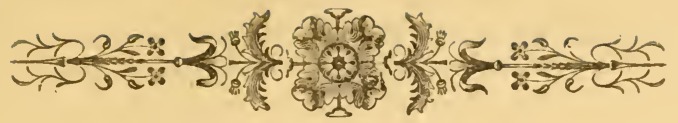

T H E

\title{
BORDER ANGLER.
}

\author{
$\rightarrow 883300-$ \\ CHAPTER I. \\ I N T R O D U T ORY.
}

$\int 00=1$

HE keen Angler who has nothing to do but to pursue his sport, will probably, during the trouting season, erect his tabernacle by some river-side, where the murmuring stream will at night "invite him to rest," and in the morning to recreation, and where he will be in a position to take advantage of those fleeting moods favomable to the exercise of his art which air and water sometimes assume. As, however, there is a large number of keen anglers who cannot make it convenient thus to ruralize-whose ways of life are amidst the stir of cities, and who can snatch only in the intervals of business an occa. sional day or two for their amusement-the next thing to be desired is the enjoyment of such facilities for conveyance to the water as shall neutralize, as far as possible, the drawbacks to which the distance of their 
residence subjects them. Perhaps no city in the island is so excellently situated in this respect, or so fully provided with these facilities, as Edinburar. Indeed, considering the number and the variety of streams which are every morning at the command of the inhabitant of "the grey Metropolis of the North," it is doubtful if he is not as well stationed in Edinburgh as he could be if he were to choose for himself a dwellingplace on the very margin even of his favourite stream. In a period varying from one to three hours, the Edinburgh man of business can be whirled to the banks of the Clyde, the Forth, the Teith, or the Tay; another hour or so will place him on Loch-Lomond in time to have a cast and be back to his abode at night; he may even start from Waverley Bridge in the morning, and by the afternoon have his line wet in Highland Dee. And, more valuable and convenient than all these together, he can breakfast quietly at seven o'clock, and by nine or ten be busy at his sport in almost any of those delightful streams which make the south-eastern counties of Scotland his land of hope and promise.

Never surely can Railways and Rivers run more lovingly together than the North Britisn and its Branches, and the Tweed and its branches. From the moment you surmount the acclivity in which the GALA rises, until you arrive at one of the various terminiSelkirk, or Hawick, or Jedburgh, or Berwick-you scarcely lose sight of some stream or other, famous in Border song, and high in angling repute. There you go down the vale of Gala, with that river of "braw, braw lads" twisting and twining round the iron road, making many a pleasant and coquettish bend, but 
never going out of sight, and growing every mile under your eyes, until it is lost in the mazes of Galashiels mill-leads. You leave it only as it accomplishes a union with the Tweed (although not until intercourse with a manufacturing town has sullied its native purity -as intercourse with manufacturing towns is too apt to do with both water and humanity), and then you go careering past ancient towns, decayed abbeys, ruined castles, and battle-fields, through the classic land of Scotland, but ever, at intervals of three or four miles, with a stoppage at some station, "mighty convanient" for the bearer of rod and creel. The mere enumeration of the streams which are crossed by the North British Railway and its branches or continuations, is like calling the roll of the waters best loved by the angler. The Esk, the Tyne, and the Eye, on the Main line to Berwick; again the Esks, North and South, the Gala, the Tweed, the Teviot, and the Till, on the line to Kelso and by the Branch of the North Eastern Railway to Berwick; the Ettrick on the Selkirk branch; the Ale on the Hawick branch; the Jed on the Jedburgh branch; and the Whitadder on the Dunse branch; while stations on these lines give the angler command of the Yarrow, the Leader, the Kale, the Rule, the Eden, the Leet, the Bowmont, and the Blackadder, and of almost innumerable burns which ought not to be without places in an angling catalogue.

It is the object of this little volume to point out the best stations for these different streams, to delineate the various characteristics of our border rivers, and to throw out a few hints on the modes of angling 
adapted for each. We shall lead the angler by quiet waters and unquiet waters; by "dubs" and "trows," seething "Hell's cauldrons" and calm mill-dams; we shall show him alike the "grace of forest charms" on sylvan Teviot, and the "pastoral melancholy" of the "dowie dens of Yarrow"-now point out the hauld of the Salmon, and now the home of the Trout; and shall bring him to many an "honest alehouse" and com". fortable hostelry, where he may rest and refresh himself after his pleasures and his toils.

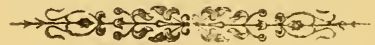




\section{$(5)$}

\section{CHAPTER II.}

\section{ANGLING ON THE BORDERS.}

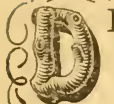

IO tells us that the Mrata, the aboriginal inhabitants of probably the whole country between the two great Roman walls, and eertainly of the south-eastern borders, amongst other peculiarities of habit, abstained entirely from the use of fish. Tweed was running then as now : the Salmon, with no 'T-nets at Goswick and no stell-nets at Berwick to stay his course, must have been "belling" and "ower-setting" in every pool, and swarming up all the tributaries, then unpolluted with mills and factories; - the Trout, when the shower of ephemerce came daily over the water, must have made it boil like a cauldron. Yet no fly or worm was thrown to tempt them-no leister launehed at them, no cairn-net quietly dropt in an eddy, and no deadly straik-net drawn through their homes to deeimate their numbers. Foolish Mrata! - unworthy progenitors - if indeed they were so in any degree-of the black-fishing ich. thyophagi of the Teviot and the kipper-consumers of Peebles! We may be sure that when their Roman conqueror fixed his eamp at Lessulden, he was not long in fathoming the mysteries of The Pot, * or in putting

" "The Pot" is the name of a noted salmon east in the upper Jiertoun water, near St. Boswell's. 
his camp-kettle to what its shape would argue to have been its legitimate purpose-that of boiling the shoulter or "tail-scud" (Tweedside phraseology) of a noble salmon. Wiser too in their generation than the aborigines, were the Monks of Melrose, of Dryburgh, of Kelso, and of Jedburgh. Well did they use, and carefully did they guard, the piscarial rights conferred by their charters ; and many were the laws which, doubtless in great measure through their influence and that of the Border Chiefs, the Scots Parliament passed against fishing in breeding-time, and against the taking of salmon by the profane vulgar for less sacred uses than the comfort of conventual stomachs and the gracing of baronial boards. We mistake the character, however, of the ancestors of the present breed that inhabits our border counties, if they did not get a quiet share of what was going, or if the taste and flavour of the different species of the salmo which frequent their waters were unfamiliar to their palates. Indeed, notwithstanding the severity of the penalties attached to illegal fishing, fish were so plentiful, and there were so few ways of getting rid of them, that, according to the often-told story, within the last two hundred years servants and apprentices made it part of their agreements that they were not to be required to eat salmon oftener than three or four times a-week. Although, no doubt, the food being so rich and luscious, any stomach would rehel at having itself stuffed with fresh salmon daily, we fancy the salmon thus protested against were rather kippered foul-fish and bull-trouts, that had hung in the chimney for months, than the newly-caught aquatic prince himself. At any rate, there is no necessity for 
such a provision now-a-days in indentures and agreements, for it is only by setting the law at defiance, as his honest forefathers did, that the Hawick weaver or the Ettrick shepherd can get a mouthful even of a lean and unsavoury kelt-the fresh salmon being utterly unattainable, and less known on great part of the Borders than it is in London or Edinburgh.

The angling of the Borders is confined almost entirely in these waters to the best known varieties of the salmonidæ. There are pike and perch in Till and Teviot, but the grayling and the charr, the chub, the carp, the tench, the roach, the dace, and the gudgeon, are unknown. Eels are more or less abundant in all the streams, but the angler must be reduced to rather desperate circumstances before he sets himself seriously to fish for them. The members of the salmo family are,- the salar, or true salmon and grilse; the eriox, or bull-trout; the trutta, or whitling (if trutta be really the proper designation of this beautiful fish, which is much finer than the salmon-trout of other rivers); the albus, or herling (blacktail is the local name-a very dubious sort of animal); and the fario, or common river-trout.

\section{SALMON-FISIIING.}

The Tweed alone is worth much regard as a salmonfishing river; but for twenty or thirty miles of its course, from Coldstream upwards, it has a high reputation amongst the salmon streams of Scotland. Salmon-fishing is not, however, altogether a public amusement-seeing that salmon are private property, which trout are not. No one has a right to catch the true salmon, or any of the migratory species, save in the 
exercise of a privilege more or less directly derived from the Crown-the unprivileged angler who at any time takes one of these fish from the Tweed being liable to a penalty. There is little difficulty, however, in obtaining salmon-fishing at various parts of the Tweed, by paying for it to the professional lessees of the fishings, who live by them, and of course are willing to make money either by catching salmon themselves, or by letting others catch them; while other parts of the river are let to amateur anglers at rentals varying from $£ 50$ to $£ 100$. Even on some of these waters * the ordinary angler may occasionally obtain a day's amusement, as the lessee, who generally lives at a distance, and only visits the Tweed at the best season for sport, sometimes permits his keeper to give a day's fishing to any one who applies- the said keeper being of course gratified for his trouble and complaisance, and the fish captured being either paid for at their market value, or left with him.

Owing to the immense falling off in the number of salmon in the Tweed-a falling off attributable to various causes, but chiefly to too much net-fishingthis, the highest form of angling, has on that river greatly deteriorated. Indeed, in these latter times, angling for clean salmon from the 15th of February to the middle of June, except on a few days after favourable floods, has been almost hopeless; and salmon-fishing with the rod has really meant killing kelts in spring, grilse in summer and autumn, and a

* The salmon-fishings in the Tweed are divided into "waters," each having a special name, and being usually a separate property. 
few salmon heavy with spawn in the three weeks of grace allowed to anglers after the net-fishings have closed. By an Act passed in 1857, however, very considerable changes have been effected in the salmonlaw of the Tweed : the killing of kelts and foul fish is now prohibited, and some small-very small-additional chances of getting clean fish have been afforded to the angler. A heavy flood occurring on a Saturday (salmon are always induced by floods to leave the sea and ascend the river) gives them an opportunity of running up on the Sunday when no nets are working, and of getting within the reach of the rod-fisher. This, however, has been abont the only chance that there was; for, when all the nets were working night and day; the chances that the fish which passer Spittal Point would reach even Coldstream Bridge have been poor indeed. Those that have missed the stell-nets at Tweedmouth liave fallen a prey to the sweep-nets at Ord; those that have escaped both of these have had to run the gamtlet of many similar nets at Iorncliffe, Norham, and Tweelmill; while, if the strength of the current has induced the salmon to retire into a tempting eddy at the side to rest himself, ten to one but there has been a treacherons cairn-net to bar his progress outward, allowing him merely to get his gills through, and hang limself, when he desired again to set out on his journey.

Indeer, so rapid and alarming had been the decrease of the fish, that the necessity of doing something to prevent a hastening extinction of the salmon altogether had, within the last few years, become apparent to all but those who had really brought about the 
evil, and to whom the remedy was of the greatest importance. Salmon-angling with the rod had, as we have said, become almost a delusion-save for foul fish in spring or in the last weeks of October; and the annually decreasing returns at the lower netfishings showed that time would in all probability make things worse rather than better. The annual rental of the Tweed had fallen, within a few years, from $£ 20,000$ to about $£ 3,300$; the annual take of salmon from 40,000 to 9,000 , and of grilse from 80,000 to 15,000 . The upper proprietors, therefore, came forward with a proposal to amend the law-to shorten the season of fishing, and to abolish some of the more obnoxious modes of capturing salmon. Instead of being met in a fair spirit by the lower proprietors, the proposal was strongly opposed, and a countermovement was made, actually intended to withdraw some of the few privileges which the owners of the upper waters possessed. The result was, that in the 1857 session of Parliament two Bills were brought in-the one being the embodiment of the original proposals of the upper or rod-fishing proprietors, the other the counter-effort of the net-fishers. A large amount of evidence for both sides was given before a Parliamentary Committee, presided over by $\mathrm{Mr}$. Fenwick the Member for Sunderland. On the side of the Berwick net-fishers were Mr. Paulin, the manager of the Berwick Shipping and Fishing Company, Mr. James Paxton, the intelligent superintendent of their fisheries, Mr. Hogarth of Aberdeen, Mr. Robertson of Ladykirk, and others. As one of the objects of the upper proprietors' Bill was to abolish stell-nets, 
some aged Spittal fishermen, whose memories extended for nearly eighty years, were called to prove their antiquity. (A stell-net, we ought to explain, is the ordinary fishing-net drawn across the river, and kept in that position until the man in the boat, who has rowed it out and keeps his hand upon the rope, feels a fish strike, when it is quickly pulled in, enclosing the salmon. This net, it was contended with some reason, was a standing obstruction to the run of the fish, such as is prohibited in all salmon-statutes.) On the other side the witnesses were-Mr. Russel, editor of the Scotsman and writer of articles on salmon-fisheries in the Edinburgh and Quarterly Reviews, Mr. Richard Hodgson of Carham (Chairman of the North British Railway Company), Mr. Mitchell, the very efficient Superintendent of Tweed Police, Mr. Fennell, the Acting Chief Commissioner of Irish Fisheries, Lord Polwarth, Mr. Dunbar, innkeeper and lessee of fisheries at Brawl Castle on the Thurso, Mr. Andrew Young of Invershin, manager of the Duke of Sutherland's fisheries and author of several small books on the natural history of the salmon and on fishing, Mr. Robertson of Kelso, and others. The House of Commons' Committee unanimously rejected the Bill of the Lower Proprietors, and found the preamble of that of the Upper Proprietors proved. They decided that the fishing-season for both nets and rods should begin on the 1st of March, instead of, as formerly, on the 15th of February; and should close for nets on the 14th of September instead of the 15 th of October, and for rods on the 14th of October instead of the 7 th of November. They also agreed to the abolition of stell and all other 
fixed nets, to a slight extension of the reekly closetime, to a prolibition of the use of leisters under any circumstances, and to a prohibition of killing kelts or other foul fish. The Marquis of Westminster was the Chairman of the House of Lords' Committee on the Bill, and a number of the witnesses were reexamined before them. 'The Lords' Committee agreed in finding the preamble of the Bill proved, altering, however, the period for closing the net-fishings from the 14th September to the 30th of that month; but as they neglected to make a similar extension of the time allowed for rod-fishing, they-accidentally, we believe -defrauded the anglers of the additional week of grace which the Commons' Committee harl given them, and actually rednced the period of exclusive rod-fishing to a fortnight, instead of the three wecks that had been allowed under the old law.

These, then, are the prominent enactments of the new Tweed Fisheries Act. The annual close-time for net-fishing now extends from the 1 st of October to the 1st of March, a fortnight having been arded to each end of it. The rod-fishing close-time extends from the 15 th of October to the 1st of March. Althongh there are fish ready to spawn before the 1st of October, and some which have not spawned even at the 1st of March, the legal destruction of salmon at the point of breeding will now be very small-so that the Tweed fisher's will be freed from the disgrace of doing what was really pnacher's' work. A clause also prohilits the killing of foul-fish ; but we fancy it will only be enforced against the killing of kelts and baggots in the spring, - the difficulty of deciding when a fish becomes 
foul in the autumn probably rendering it inoperative in that season. All kelts and spawning salmon are to be returned to the water' and, in the case of rodfishing, the use of the gaff or "cleek" is prohibited until the 1st of June, in order that the fish may be so returned in as good condition as possible. 'To have foul-fish in possession is made a penal offence. "Fixed nets" and "fixed engines," which the Act defines to "mean and include stake, bag, bob, hang, sole, and cairn nets," and all nets or cruives made stationary in any way whatever, are prolibited. 'The most important net thus abolished is the stell-net, which is the principal net used at the very mouth of the river, and the abolition of which, it is loudly declared, will totally destroy some valnable fisheries. The stell-net, however, is merely the ordinary weir-shot or sweep-net, kept extended for some time instead of being immediately drawn in; and where it can be wrought the one way it can be wrought the other, although perhaps less productively. Leisters (fish-spears) are totally prohibited, and the possession of such an instrument made illegal. Four hours additional are added to the weekly close-time from the 1st of June to the close of the season, the killing of salmon liy any means between six o'clock on Saturday night and six o'clock on Monday morning being now prohibited.

It certainly cannot be said that these provisions show any marked favour to the angling interest in the Tweed. The rod-fishing proprietors have given up a great deal, in order to vindicate themselves from the imputation of selfishness, and have trusted entirely for future better sport to the generally increased pro- 
sperity of the river, of which the net-fishings will of course enjoy immensely the greater part. The right of kelt-killing being given up, probably few of the upper proprietors will put up their rods at all in the spring; and leistering being also put an end to, the fish will unmolested drop down from their spawning-beds to the ever-renovating sea. When, about Coldstream and Tweedmill, they encounter the nets, the honesty of the booted fishermen will be tried as they draw in haul after haul of fish which they are obliged to return to the water, probably not half-a-dozen clean salmon turning up for every hundred kelts! Heaven strengthen ye, O ye sorely-tempted Scotts and Kersses! The Berwick Fishing Company some years ago made a point of returning the kelts caught at their stations to the water; but as many of these fish just fell a prey to other fisheries that were interspersed with theirs, we believe they latterly gave up a practice that did them much credit. They will, however, no doubt very gladly resume it. The cairn-nets, the abolition of which was proposed by the upper proprietors themselves, caught, according to Mr Russel, something like $6-7$ ths of the clean fish killed in the upper waters. This of itself proves the spirit in which the angling proprietors approached the subject; for nothing can be said against cairns, which project only a few feet into the water, and are no obstruction to the run of fish, except that they afforded facilities to the poachers in close-time. Sport, and not fish merely, was, however, the object of the upper proprietors, and it is to be trusted that it will turn out they have acted wisely as well as disinterestedly. 
The extent, however, to which kelt-killing had been carried of late years on the Tweed, by both net and rod, was simply atrocious. We bẻlieve it was no exaggeration of the newspapers to state, at the opening of the season in 1857, that "tons of kelts" had been captured by net the first day ; and the mere summing up of those enumerated by the border papers as having been taken by the rod for sport at the different "waters" during the first week would not give a less figure than 1000. One dealer in Kelso purchased 2000 Hbs. of these fish after the season had considerably advanced, the market for them being principally Paris. The large midland towns of England were for several years privileged to buy them and eat them as "Tweed salmon;" but a tour made throngh these towns by the Superintendent of Tweed Police blew up that market, and probably caused the stream of supply to be turned towards France. We defy even the cooks of the Palais Royal to make a kelt that has been carried from the Tweed to Paris wholesome or good, however much their craft may disguise its real character. Kelts cannot, except perhaps as kipper's, be eaten with relish or even safety; and when the Parisian gourmet has flourished his napkin over his saumon a l'Ecosse, he has not known that he was eating what even the stomach of a Selkirkshire shepherd, the gastric juice of which had been fortified by a preliminary mutchkin of whisky, would revolt and "scunner" at. Tweed has long been a standing anomaly in respect to kelt-killing. On no other Scottish river were these fish allowed to be taken by law; and, although there is perhaps a little truth in the argument that Tweed kelts are much 
better than other kelts, the fact that a kelt sold for only $4 \mathrm{~d}$. or $6 \mathrm{~d}$. per pound, at the time that clean salmon were selling for $2 \mathrm{~s}$. 6 d. or 3 s., sufficiently disposed of that, and showed the monstrons waste caused by the killing of these animals. A few years ago, every spring some disgraceful butchery was committed on the Tweed and the Teviot amongst the kelts with the leister, by noblemen and otliers high in the sporting world; but a little salutary exposure in the sporting papers put a stop to it, and for several years it has not been renewed. Two of the foremost of these slew no fewer than 300 fish in one light between Melrose and Leader-foot; and from fifty to eighty kelts a-night were frequently killed. When we consider that the yearly take of clean salmon in the Tweed by all means is now not rnore than 8000 or 10,000 -in 1856 it was only 5000 -it is not too much to assume that in this rutliless kelt-killing we have one of the causes of the constant rechuction that has been going 011. Angling for kelts was salmon-fishing in its coarsest form; and, although far inferior to the true sport, when clean salmon or grilse are the objects of capture, it was yet sufficiently cuticing from the numbers and readiness of the fish in takirig, and exciting from the strength which they sometirnes displayed.

The Tweed cannot be fished for salmon satisfactorily without a stiffish rod of from 17 to 19 feet in length, the reel containing from 80 to 100 yards of line. The salmon-angler's tackle varies with the season of the year and the state of the water. We do not know of any principle which should guide him in his choice of flies-except perhaps that of adapting them 
to the condition and colour of the water-when it is black and heavy, using a larger and lighter-coloured fly than when it is low and clear. There are salmonflies described as "Tweed flies" which may be assumed as the most generally-killing that can be used; but probably it would be impossible to cover a hook with feathers, mohair, or tinsel, in such a way that a salmon would not rise at it; while flies that are the very opposite in their characteristics to the Tweedflies proper, are occasionally the most successful. Irish flies are now very generally used; although Mr. Stoddart has a legend that a few years ago salmon would not look at them! Half an hour's talk in the shop of Forrest of Kelso, with John or Willie Younger at St. Boswell's, with Jamie Wright at Sprouston, or with any of the sons of the tribes of Kersses, Purdies, and Scotts, who fish and guard the Tweed, will, however, give the angler more knowledge of the subject than he could get from any treatise; while if he were to talk with all of them in succession he would probably be in possession of several theories, each inconsistent with the others, and with innumerable facts apparently contradictory, all forming capital materials for his powers of generalization to work upon. Of course, it is his business to construct a theory and system of his own; and all that can be done is to help him by a few general directions. As matters stand, it is very unlikely that a salmon-fisher who requires elementary instructions in the art will find himself on Tweedside without a keeper along with him to direct him. Indeed, salmonfishing must be learned by observing the modus operandi as practised by one acquainted with it; and for 
success in it, so much depends upon the personal qualifications of the angler and so little upon any wellascertained or definite principles, that the good salmonfisher is generally a law unto himself, regardless of the maxims of Scrope, Stoddart, and Ephemera. On Tweedside, you will find a man fishing on one "water" with flies that would be rejected (not perhaps by the fish but by the fisherman) on the next; and all that is generally agreed to may be summed up in a few simple rules laying down the necessity of light and far casting, of regulating the motions given to the fly according as you are fishing for kelts, for clean salmon, or for grilse, and according as you are fishing in stream or pool, and of using large flies in spring, small ones in summer, and again larger ones in autumn. And the best salmon-fisher in the world might, after all, in the season when the fish are scarce in Tweed, if he were not intimately acquainted with the water he was fishing; throw away all his labour and pains for nothing, while an indifferent angler, knowing the water, might be successful. It is altogether impossible for a stranger at once to fix upon those places which are worth fishing; and although a general knowledge of the habits of the fish may teach him what are the likely places, it is quite possible that he may spend his time in anxiously thrashing where salmon never lie, and may pass over those casts where they are almost always to be found. A Tweedside fisherman can point ont almost with certainty, from his long observation, the spot where a salmon is lying, if there is a salmon in his district; and these places vary with the state of the water, one cast being excellent while the river is large, another while it is small. 
The day of kelt-fishing being past, it is unnecessary to enter at length upon the habits of the salmon while it is in that state. Weak and worn-out by the labour of spawning, kelted fish fall back from the streams in which they have been carrying on their breeding operations, into quiet pools, where they can lie at ease without requiring to use that constant exertion of fin necessary to their maintaining their position in strong running water. The "tail of the stream," just where the water is losing its visible motion in the pool, is perhaps the most favourable place at the opening of the season-or the pool itself if the water is heavy or if there is a good wind; but as the fish begin to "mend" (that is, to recover strength and condition, which they partially do as they descend to the sea), they advance more freely into the streams, and a straggler may be caught almost anywhere if they are plentiful. It may be regarded as a maxim in all kinds of salmon-fishing, however, that the fish lie and feed chiefly where they can find some sort of shelter behind a large stone or beneath a shelving rock. It is from a hauld of this kind that the salmon, kelted or clean, keeps a look-out upon the stream; and, as the fly comes temptingly past it-with short jerks contending with the current, and opening and shutting its wings in its apparent efforts to hold its own-the fish sails warily out, follows it round for a few yards, and finally, as it appears about to leave the part of the water that is his peculiar domain, makes a rapid plunge and engulps the treacherous steel. Often, however, a salmon will unaccountably and tantalizingly follow, time after time, the fly as it passes, without attempting to seize 
it; or, worse still, he will rise at it, once and again, making an exciting splash or boil in the water, but carefully abstaining from taking hold. The ordinary practice of anglers, in such cases, is to change the fly; and by patience in giving the fish pretty long rests between the casts, and perseverance in trying him again and again, he is generally induced at last to make a serious attempt, and to become the angler's partner in that whirring waltz that lands him finally -more exhausted even than the miss who has been whirled a dozen times round the ball-room by an over-vigorous officer-upon the green sward or the grey gravel.

The clean spring salmon disdains the company of kelts and "bubblies" in pools and caulds, and "keeps himself to himself" in the surging streams and boiling eddies. So few there be, however-or we should perhaps say, so few there have been-of such fish, that the casts favourable for them in Tweed are almost systematically passed over; and it is not until the rejoicing tidings have passed upwards from Berwick that the grilse have begun to enter-which is usually about the middle of June-that the angling fly begins its preposterous antics in the true salmon-streams. (We say the antics are preposterous, because no fly that is born of a chrysalide could ever by any possibility struggle against the current as the angler's fly does.) From the middle of July till the close of the season a favourable flood is sure to bring a grilse or two into every "water ;" and it is during this period that

* The Tweedside fishermen on the lower waters contemptuously designate a bull-trout kelt a " bubbly." 
the best salmon-fishing is always had. An occasional salmon is also to be got; and hitherto, in the three weeks' grace that has been allowed to the rodfisher, if a fresh opportunity occurred, a large number of pretty heavy fish-often, however, far advanced towards spawning-have been captured. It remains to be seen what changes in the sport will result from the alteration of the salmon season in the Tweed; but we believe experience shows that, in the first fortnight of October, when the nets have hitherto been diligently plied, more fish, and those in better condition, have of late years been taken than formerly. So much so, that a very intelligent and careful observer (Mr. Paulin, of Berwick) argued from this that the habits of the salmon, in respect to spawning, were becoming later, and that therefore there was no necessity for an earlier closing of the river. In the month of September, the fish used to crowd in large numbers into the Tweed; and a lull then occurred until about the beginning of November, when a flood brought away the first real shoal of spawners, and every cauldside was alive with them struggling to get up. The season of grace allowed to the rod-fisher was thus about the very worst in the year. If it should prove that the fish are now running later, and that the last batches of clean fish come in so late as the first fortnight of October, it will, of course, be all the better for the angler. Such, however, was hardly the experience of last season (1857), respecting which the Kelso Mail, summing up at the close, declared that "a more unfavourable season for the angler had not occurred for a number of years." According to the 
same journal, the number of fish killed during the last fourteen days allowed for angling, between Coldstream and Peebles, did not exceed 150.

Angling for salmon is also practised with worm and with parr-tail, and even clean fish are sometimes killed with minnow. Under peculiar circumstances wormfishing for salmon is often very successful. It was first, we believe, described by Mr. John Younger of St. Boswell's, and the method he recommends is this: Two large round-bend hooks are tied upon the strongest gut, the one a little above the other; two or three large lob-worms (well scoured) are run upon these hooks; if three, the two first must be drawn over both hooks while the third covers only the lower-pains being taken to cover all the wire, and the gut between, and an inch or so of gut above the upper hook. Only one hook may, however, be employed, and in this case the point ought to be brought through and reëntered several times, making folds in the worms. The line ought to have a swivel, and to be very heavily leaded, as the places suitable for this kind of fishing are the strong streams, and it is necessary to search the bottom with the bait. The water must be low and clear, but even in these states it is not always that this kind of fishing can be successfully practised. Perhaps the best time is a frosty morning towards the end of the season, when the mist is rising from the river, - when the pocket-pistol is often in requisition, and when an accidental "jaw" of water over the tops of his wadingboots makes the angler shudder. The most important direction to be given for worm-fishing for salmon is to be careful not to strike or in any way to check the sal- 
mon when he seizes the bait. The angler must hold a yard or two of line in his hand, unwound from the reel, and keeping down the point of his rod, mist let it out, with whatever more is required, as smoothly and uninterruptedly as possible. The salmon at first merely seizes the bait in his mouth, in the manner of the pike, and proceeds to his hold before attempting to swallow it. The angler must not be induced to strike even by pretty strong tugs from the fish, as he is then merely mouthing it, and must wait until he stops, or until something like a steady pull upon the line takes place.

Parr-tail and minnow are more enticing to kelts than to clean fish, and it is difficult to state the times at which these are particularly tempting baits to newly-run salmon. The best rule is to resort to them only in circumstances when fly-fishing is found to be unsuccessful. The baits, both the parr-tail and minnow, ought to be larger than those used in trout-fishing; the tackle ought of course to correspond with the baits and the strength of the fish angled for ; and the spinning ought to be rather more deliberate than when trout are the object in view. The ordinary salmoncasts are the places adapted for them.

Of course the first great point in salmon-fishing is to hook the salmon; but even then, it is rather premature to count upon the shoulder-cut for dimner. The " monarch of the tide" is still in his own element, and he must be caught before he is cooked. It is difficult to give general directions as to the proper management of a hooked salmon, and we have not space to enter upon the controversies about keeping 
a long or a short line, \&c. The fish himself generally takes the matter pretty much into his own hand (or rather fin), and the simplest recommendation to the angler is to keep all the command over him that he can, consistently with the safety of his tackle. It is more frequently the case that a fish escapes from not being tightly enough held, than from the line breaking or the hold giving way, through too heavy a pull being put upon it. When the fish leaps into the air, it is judicious to give a little line, or perhaps slightly to lower the rod, in order to save the line from being tested by the whole weight of the salmon as he falls back. When he appears to be making for a dangerous place, for rocks or tree-roots where the line might be cut, the angler must unflinchingly present his butt, keeping his rod back over his shoulder, thus bringing all possible pressure to bear upon the fish. Should Salmo, indeed, try to go down t'other side of an island, or throngh the wrong arch of a bridge, or anywhere else that the angler cannot follow, there is nothing for it but " pull devil, pull baker," until the line breaks or the fish gives in-although we may mention that a salmon has, on such occasions, been sometimes induced to alter his course by a sudden relaxation of the strain, the notion being thus put into his head that he was told to go on! A hooked fish will sometimes "sulk," -that is, lie down in the bottom of a pool,-and it has happened that no amount of tugging or of stonethrowing at him could then induce him to move. If the angler in such a predicament retains his desire to possess the fish, he must just sit down, or in any other way strike the attitude of patience on a monument, 
until his salmonship pleases to move. The best way of pulling at him in such case is by getting below him ; and if he can't be moved in that way, he can't be moved at all. The safe rule in running a fish, however, is for the angler to have tackle in which he has some confidence, and then, avoiding all jerks or sudden strains, to maintain as firm and constant a control over the salmon's motions as possible, until the fish is exhausted. Then leading it gently to some favourable place on the bank, he may either strike a gaff into its shoulder or through its gills, or encircle it in a large landing net. If he has an assistant to do so for him, all the better, although we deem it hardly sportmanlike for anglers to have their assistants watching every opportunity to "cleek" the fish before it is exhausted.

\section{TROUT-FIS HING.}

Of all kinds of sport, trout-fishing, to the people of Scotland, is the most generally accessible. It is also that which more than any other calls forth, or gives occasion for the exercise of, the ingenuity, patience, sagacity, and endurance, which enable man to conquer the instincts and outdo the wariness implanted in his prey for their protection. The sharp-sightedness, cunning, and timidity of the trout-and especially of the trout of our much-fished border-streams-are proverbial ; but even these must yield to the dexterity and superior acuteness of the angler, who, using a line almost invisible in its fineness, passes off a feather for one of Nature's insect masterpieces, and makes a worm or a minnow the tempting disguise by which to introduce a barbed hook into the mouth of his not easily-deceived 
victim. Angling re-awakens in him who practises it the original faculties by which man gained his food before he took to plonghing, or pettifogging, or cottonspinning; and he must have re-acquired in a considerable degree the power of exercising those faculties before he can daily fill his basket with trout from the Tweed or its tributaries. He must be able to unite in himself the man of the time when the world's grey fathers came forth from the Ark, after the fishes had for a season had it all their own way over the deluged earth-and who would doubtless have to take to fishing for their food, until the corn grew, or the veal was ready-with the man of the nineteenth century, who moves about amongst whirring wheels or pores over papers, and whose dinner is sure every day in the year, without his knowing whence it comes. But as it may perhaps be said that the praise of fishers and of fishing has already been said and sung to a sufficient extent by members of the fraternity, we had better pass on to the more particular business before us. Our functions are those of a guide rather than of an angling preceptor-Wilson, Stoddart, Younger, and Stewart, and hosts of others, have described the mysteries of the art as practised in Scotland, as well as they may be described-and therefore our instructions shall be brief.

Fly-Fishing, by general consent, stands first in the angler's practice. It is the most elegant mode of fishing-the simplest in respect of tackle (seeing that no bait is needed), and in some measure the easiestand it is that which, taking the whole year into account, is perhaps the most generally productive. 
When we say it is the simplest and the easiest method of angling, however, we mean only that by it almost any angler can capture an occasional trout; we are very far from saying that it is that in which proficiency is most readily attained, or in which there is little room for the exercise of skill. On the contrary, to make fly-fishing really productive requires the union of all the angler's highest qualities. Knowledge of the habits of the fish, quickness of eye, dexterity of hand, the most unwearying perseverance against difficulties - these are all combined in the man who, as in the case of some border anglers, would make the river yield him as much daily as could be converted into daily bread for a family. As we fancy most of our readers are already acquainted to some extent with the principles or practice of angling-and as we deem it utterly hopeless, by means of a book, to attempt to teach a man to fish who has no previous knowledge of the art-we shall, in treating of fly-fishing, do little more than notice some most important improvements in it that have been lately promulgated by $\mathrm{Mr}$. Stewart.* The old method of fly-fishing, in its highest form, was "fine and far-off" casting across the stream, and letting the flies float down below where the angler stood. Many an overflowing basket has been filled in this way, when circumstances were favourable, or in cases where individual expertness overcame what are undoubted disadvantages in the method. But rivers ran more favourably for fly-fishing long ago, before the lands which feed them were so much drained; and

* "The Practical Angler; or the Art of Trout-Fishing, more particularly applied to Clear Water." By W. C. Stowart. Edinburgh : A. \& C. Black. 
trout were more easily caught than now, from there being fewer anglers to make them practically acquainted with the difference between a real and a false fly. It has been becoming yearly more and more difficult to get a basket of fish out of streams which run clear as crystal during almost the whole angling season. Mr. Stewart has therefore stepped in most opportunely with a way of getting over this. $\mathrm{He}$ recognises as the first principle in angling, the concealment of the angler and of his tackle. "Surely in vain is the net spread in sight of the bird," saith the Scripture; and surely in vain do you angle, says the Practical Angler, if the fish sees you, your rod, or your line. But how to prevent this-when the waters are clear and a May sun shining into them, if you have to present yourself on the bank before the trout's very nose? There is indeed no way but this: you must get behind the trout. Owing to his anatomical construction, a trout never looks over his shoulder. He lies with his head up the stream, ard notes most accurately anything that floats past him in the water, or any apparition that is exhibited on the bank above or opposite to him. But if you stand a little below, and not-if you are a six-footer-too much above his level, the ehances are that he does not perceive you. In this position you can throw your fly above him, so that he can catch it, as he does that of which it is "the counterfeit presentment," as it comes down-with the secondary result of your catching him. A repetition of the process fills your creel. It is not to be understood from this, however, that the cast is always to be made straight up stream. By a straight-up cast the 
whole of your flies must pass over the trout-as rell as the line-probably to the excitement of suspicion or alarm. On approaching a pool, therefore, at the foot, the first cast may be made straight up the side of the bank on which you stand (or crouch, or kneel, which are preferable attitudes), but the succeeding ones should be more and more diagonal, until you throw across to the opposite bank, or in the direction of it, if the river is too broad for that. It is at the opposite bank that you are to expect most fish, and if you are fishing a stream which you cannot command from one bank to the other, the best plan is to wade into the middle, and cast across and upwards to the side. In places where the water does not run into the bank, and where it is shallow at the edges, deepening towards the middle, trout do not lie at the side; and to the middle, therefore, especially to the eddy behind every large stone, the angler should address his efforts : but these are hardly the most favourable places for fly-fishing.

A bad angler, however, usually chooses some such smooth and equable stream, and keeps casting away over and over the same spot, for hours together. He has been told to fish his water inch by inch, and he thinks it necessary to give every parr half-a-dozen chances before he passes it. It is indeed the besetting sin of anglers to linger too much over the water, and to make long casts, which are as vain and profitless as long prayers. $\mathrm{Mr}$. Stewart (whose valuable instructions we are very imperfectly summarizing) recommends quick, almost constant casting, and rapid movement from stream to pool, and from pool to stream. In fishing up-stream, frequent casting is necessary, or 
the line floats down past the angler. But the trout usually rises to the fly the moment it falls, and it is undesirable to let the line float for more than three or four yards, each cast being made a yard or two above the preceding one. The eye of the experienced angler at once detects the points of each stream and pool, and he does not waste time by casting in water where trout do not ordinarily feed, but having brought his fly in behind every stone, below every bush, and past every tuft of grass, he passes on to other favourable places. Fly-fishing, indeed, or any kind of fishingif the angler makes up his mind to fill his pannier-is hard work. What his hand findeth to do, he must do with his might, confident that skill and diligence will meet their reward. Unless a stream is remarkably well stocked with trouts, and singularily adapted for the catching of them, the angler in a full day's fishing ought to pass over from four to seven miles of water. It is waste of time to fish all the water-it is folly to repeat casts, except where there is some special temptation-and, when the take is not on, there are but a few trouts here and there, stationed where the angler's eye ought readily to direct him, that are feeding. When the talie is on-that is, when of a sudden the water begins to "bell" with noses poked up to catch the drowning flies that suddenly come down the stream in myriads-the angler must redouble his exertions; and as he ought to get a rise at almost every cast, if he is in a proper place, he may remain stationary as long as the trout continue to seize his flies. Such golden minutes are not to be thrown away, for "the take" seldom lasts long. It 
seems to be caused by the bursting forth of a swarm of insects, which, issuing in the fullness of their time and of their wings from below the stones, begin their precarious dance along the surface of the water, in which they soon terminate their few minutes of winged existence. It is, we may remark, a mistake to suppose that the life of these insects is ephemeral. They have been alive, and pretty active, for months before, under the stones in the water or at the water-side, and their wings are merely the garb which they don to dance merrily to their death.

As it is chiefly the necessity for the concealment of the angler that renders it desirable for him to fish up the stream, he should take every means in his power to render that concealment complete. He must take care that his shadow or the shadow of his rod, does not fall on the water; and he should also constantly consider whether, when standing erect, he is not likely personally to attract the attention of trout lying where his fly has fallen. In most cases, indeed, he must stoop to conquer. He must often creep, he must sometimes crawl-not only emulating the wisclom, but imitating the motion, of the serpent. When he stands erect, the trout's line of vision towards him is only through a small portion of the water, and the greater part through the air; when he brings himself down nearly to the trout's level, the line of vision has to pass obliquely through a quantity of water before it rises, so that though he may be full in view, probably the trout cannot see so far through a medium so dense. Next in importance to concealment of himself, is concealment of his tackle, and, to effect this, we shall 
only advise him to use the very finest stained gut that he can procure, and to drop his flies as gently upon the water as he may.

Respecting flies, we must recommend our readers to the Kelso, Sprouston, or Edinburgh tackle-makers. The best authorities on Scotch angling are dead against the English practice of carrying about an artificial entomological museum in a pocket-book, and restrict the flies that may be used with advantage to a very limited number. Red, black, dun, and mottled spiders, made of soft hackles-the hare-lug body with wood-cock or greyish wing-a yellow-bodied fly, with a brown wing and slight hackle-the march-brown (most serviceable in the Tweed) -and a few others, all of suber hue, afford sufficient variety for border-angling. Fly-fishing commences in March-although, no doubt, trouts will sometimes take the fly in February;-but it is not until about the beginning of April that they begin to recover from the effects of spawning and of the spare diet of winter. In few rivers, indeed, are they in good condition until the end of that month. Flies for the early part of the season should be large, dressed upon No. 10 of Bartlett's or No. 3 of Addlington's hooks, and if the waters are discoloured they may be even larger. It is of importance to adapt the size of fly to the condition of the water; but as the seasun advances, the size may be reduced as far as is consistent with safety in retaining hold of the fish. If it is found that a considerable proportion of trouts get off after being hooked, it may be assumed that the hook is too small, and though fewer fish may probably be raised, more will be creeled by using a size larger. 
As a rule, Jarger flies may be used in the Tweed than in any of its tributaries or in smaller streams. Fineness of gut and lightness of construction-the wings being gauzy and the body slim-are of more importance in the fly than the precise shade of colour. The fly-fisher's rod should be so light as to be capable of being used with one hand for a whole day without fatiguing the angler. It must also be pretty stiff, to enable him to strike with instant rapidity, and to throw if necessary against the wind. It cannot therefore be long, and to our mind about 11 or 12 feet is the longest that will suit most people.

Next to Fly-fishing, both in the order of the season and in general estimation, comes Worm-Fishing. Worm-fishing may be practised the whole season through, and trout may probably be canght with it every day in the year. We have taken them in that way when a dead worm froze to brittleness if kept a few minutes in the air, and the dropping water icicled on the line. But worm-fishing proper does not begin until the trout have fed to satiety upon the abundance of insects called forth by the summer sun; and it is usually about the beginning or middle of June that it becomes for the time the most deadly and satisfactory of all modes of angling. Trout in the beginning of the fly-fisher's season are to be found chiefly in pools, their strength not yet enabling them to lie with constantworking fin in rapid water. But as the season advances they move into swifter currents; and when worm-fishing commences, they are distributed through all the shallow streams-posted behind stones-lurk- 
ing under banks or bushes-and taking advantage of every ripple and eddy to conceal themselves. A careful scrutiny will often detect large fish in water not of sufficient depth to cover their back-fins. To these places the worm fisher must address himself. His rod ought to be a two-handed one, 14 or 15 feet in length; his gut, for a couple of yards from the hook upwards, the finest that he can procure. By tying his hook upon coarse or white gut, he will in most cases spoil his day's fishing entirely. It is absolutely imperative that in summer worm-fishing he should cast up-stream. All the reasons for this that we have mentioned in describing fly-fishing apply equally here, and there are others that will readily occur to him. He must not use lead to weight his line, and cause it to fall with a splash, catch stones, and give his worm an unnatural motion. He must take every precaution to conceal himself from view; and his worms must be well-scoured and lively, so as to tempt trout at the season when they are most highly fed. Such reptiles he will find in all the Edinburgh tackle-shops at a very low price; but if he happens not to have access to Edinburgh, he has only to dig them from the earth -choosing such as are rather under than over two inches in length-and to keep them for a week or ten days amongst dry moss, until they slough off their pollutions, and become clear and tough. The wormfisher must pass over much water in most rivers. Pools and deep gushing streams it is useless to fish in-although occasionally, when there is wind, trout are to be taken thus in the thin ruming water at the foot of a pool, and in a gale, worm may be angled 
with almost like fly. The hook ought to vary in siz. according to the general size of the worms, but perhaps it is undesirable to use it larger than No. 11 or smaller than No. 8 of Addlington's. The point of the hook should be inserted a little below the head, and the body of the worm drawn along the shank until it completely cover's the hook, leaving about one-third of it to play beyond the point. Mr. Stewart recommends a worm tackle made up of three or four small hooks, Nos. 8 or 9, Bartlett's ( 5 or 4 , Addlington's), tied to the end of the thread of gut-the bend of the one hook nearly touching the top of the one below itand the points of the hooks merely passed through different parts of the body of the worm. This gives the worm a more ratural appearance, and makes the angler sure that when the trout seizes the worm there will be the point of a hook in its month; but, of course, on a narrow inspection, the trout will observe the hooks or gut. We have had little experience of it, but have heard it praised by old anglers who have tried it. In using it the angler :must strike rapidly, as in flyfishing; while, in fishing with one hook, he must let the trout have a bite or two before he strikes.

" Worm-fishing," says Mr. Stewart, " is the most certain and deadly of all fishing; and by it more trout may be captured in the month of July than by any other means in any other month of the year. And he is not worthy of the name of angler who cannot in any day of the month, when the water is clear, kill from fitteen to twenty pounds weight in any county in the south of Scotland." Tested by this standard, several very worthy persons of our acquaintance, who think 
themselves no small shakes with the rod, are "not worthy of the name of anglers."

Worm-fishing may be successfully practised at all seasons when the waters are muddy after a flood, and before they begin to settle into the brown or porter colour which old fly-fishers like. The angler may then load his line so as to keep it at the bottom, and may use a couple of hooks a yard and a half apartfishing chiefly at the side about the foot of streams, and in eddies.

The Creeper is a bait but little fished with on the borders, althongh it is easily got, and is very killing. It is the undeveloped stone-fly (Phryganea), after it has disencumbered itself of the shell of sand and straw in which it lived as a caddis-worm, and before it assumes its wings. It is found under the stones in shallow water in most rivers; and, with a number of legs, runs about with considerable alacrity. It has something of the appearance of a beetle, and is sometimes called the water-cricket. It is fished with precisely like worm in clear water, and in the same kind of water ; although in the end of April, when it comes into use, it may sometimes be used with advantage in deeper streams. It may be baited upon a common worm hook, passed through it side ways and back again, or upon a couple of hooks of a smaller size, one of them sideways through the shoulders, and the other in the same way through the lower part of the body. 'T'uwards the end of May it is a most effective bait for large trouts, when brought skilfully into the eddies behind stones and under banks. We have heard of 
several dozens of trout, averaging fully a pound each, being taken by it by a single rod in the Tweed in one day.

About the beginning of June the creeper developes into the MAY-FLY - a name which on the borders designates the stone-fly, and not the true May-fly or green drake (Ephemera vulgata.) The creeper then, after having lived solely in the water (although able to live for a considerable time out of it), walks out into the channel at the water-side, throws off another shell, gets large brown wings, and becomes a denizen of the dry land. In this state, few large trout are able to resist it, as it floats down the river ; and, when carefully fished with, on any day during the short fortnight or three weeks in which it is to be found, it will always command a basketful of the best trouts. Using a very fine line, and casting up-stream, so as to let it come down to him, the angler must carefully watch it, and strike pretty sharply when his line stops if the fly is submerged, or allow a moment before striking if it is floating on the surface, and he sees the trout take it. Mr. Stewart recommends the angler with the May-fly always to keep his bait under water, as he is of opinion that trout more frequently miss taking hold when it is afloat; but we cannot say that we have observed this, and it appears to us more natural that the fly should be kept on the top of the water. What we take to be the female fly is larger, yellower, and has bigger wings than the male, the wings of which are not usually longer than its body. The female is undoubtedly the more captivating to the trout, and may be used singly, while it is advisable to put on two of the 
others. Two hooks, the upper one of the size of a large fly-hook, and the lower the very smallest worm-hook, ought to be employed, and the baiting is managed by entering the lower hook below the shoulder, passing it through sideways, and bringing it back, while the upper is passed through the shoulder, also sideways. When two flies are used, the lower hook, after the first is put on as described, has merely to be passed through the shoulder of the second. Sport may, however, be had with a single hook, and we have used the May-fly pretty effectively upon an ordinary fly-hook, from which the wings had been cut. With the May-fly it is of little use to keeping whipping water inhabited only by small trout; but wherever large fish harbour, or are observed feeding, it may be used with deadly effect. A hot sunshiny day and clear water are favourable for it, but it is also productive when the water is brown, and we have had good sport with it in a gale, when it was difficult to keep the line in the water. In such a case it may be used in pools, but orainarily streams are the best, as it is there that trout do chiefly feed.

Mrvyow-fishing is most effective in two states of the water-when it is red just after a flood, before becoming fit for the use of the fly, and when it is dead low in summer-time. In early spring, it may be practised with success at almost any time, in water which has just enough of flow to make the minnow spin readily; and at all seasons, when the water is clear, this kind of fishing is greatly aided by a stiff breeze. In spring or in flooded water a pretty large minnow may be used, but in summer-time the bait can scarcely 
be got too small. Of course, the tackle must be adapted to the size of the minnow. English anglers and tacklemakers have sought out many inventions in the way of artificial minnows and complicated minnow-tackle; but if the suffrages of Tweedside Gnostics were taken, glass, brass, or gutta-percha imitations would be nowhere, and a plain running-tackle made of two hooks would head the poll. The lower hook shonld be large enough to impale almost the whole body of the minnow, being entered at the shoulder, and brought out at the tail, the shape of the bait assuming the curve of the hook, while the upper hook ought to be smaller, and to be passed through both jaws. Any slight discrepancy in the size of minnows is obviated by a turn or two of the gut between the hooks round the bend of the upper one. Some anglers use, and Stewart recommends, a drag made of two hooks tied back-toback at the end of about four inches of gut, and hung on by a loop to the upper hook of the tackle. This is intended to catch, by the outside of the body, trouts which have risen to, and have missed being caught by, the minnow. Minnow-fishing, as much as any other branch of the art, requires to be practised with skill and dexterity, and when so managed large trouts are the result. The line ought to be leaded, and streams ought most to engage the angler's attention-although here, too, he should diligently search out the likely places for large fish. He ought not to indulge in indiscriminate spinning over every kind of water, as that is mere waste of time; but in all cases he ought carefully to work his minnow to the very side, before lifting it out for a new cast, as trout often follow 
the bait, and only seize it when it seems about to escape into some shelter at the edge. The dawn and the gloaming are alike auspicions to the minnow-fisher.

We shall now only briefly notice Roe-Fishingwhich many sensible men regard as no better than poaching. It has, however, its charms; and these chiefly,-that it is very slaughterous, and that it is available at times when no other kind of angling is possible or worth trying. Piscator has then no choice between fly, worm, and minnow, - his alternatives being simply fishing with roe or staying at home. No wonder, in such desperate case, that it is oftener resorted too than, all things considered, may be quite justifiable. The months for roe-fishing are from October to the middle of March, when salmon are spawning in the rivers, and trout are on the outlook for stray particles of roe from the "redds." Trout are then in bad condition; but they are very hungry and easily taken. Roe-fishing is most effective just after the turn of a flood, when the waters are still high and muddy; in clear water it is "no use." With a stiff one-handed rod, a gut line two yards in length, made of the strongest gut, no matter how coarse, and a pot of roe, the angler must betake himself to the water-side when the river is in the state we have described, choosing a steady stream about three or four feet deep, where, according to his judgment, trout are likely to have been driven by the flood. If he find such a stream just leading into a long pool, he may expect trouts. Mr. Stoddart says it is unnecessary to bait the stream, as some anglers do; but our experience 
is opposed to this view. On one occasion we filled our creel three times in an afternoon by roe-fishing, and attributed the success to our having a fresh "salmonbelly," a handful or two of ova from which we occasionally threw in. The ordinary baiting material is the oil and refuse left when the salmon-roe is cured, mixed with particles of the paste or pea, or even with boiled rice or barley, which absorbs the oil. But good fishing may be had, we have no doubt, without baiting; althongh the effects of baiting are usually attempted to be produced by several anglers going together to a cast, and, by constantly following one another, creating a scent, and attracting fish. For it is berond doubt that the roe-fisher, by the smell of his bait, attracts trouts to him, and it is therefore that he need not shift his quarters, but may confine himself to a stretch of water thirty or forty yards in length for a whole day. He may use two hooks-we prefer good-sized wormhooks-a yard or so separate, and must have only four or five yards of line out, often less. Leading his line so heavily that it slowly searches the bottom, he must throw or drop his bait in a little above him and follow it down the cast. Quick striking is necessary; the roe-fisher must not wait for a tug, but must strike the moment his line stops. He will thus often strike when his line is merely held by a stone or a weed, but if he acts more deliberately he will fail to hook two-thirds of the fish that give him a chance. He should occasionally put a worm upon one of the hooks, and will thus sometimes get fish that are attracted to, but are indisposed to take the roe.

There is one serious objection to roe-fishing, in 
addition to the drawback that the trout taken by it are out of condition,- viz. that the practice of it is a strong encouragement to the killing of spawning salmon in close-time. Hitherto a considerable quantity of salmon-roe sufficiently developed for curing has no doubt been obtained by legal fishing before the expiry of the season, but that very fact proved that the season was prolonged beyond the due period, and it is to be hoped that the alteration of the law will amend that greatly in future. Ninety per cent. of the salmon-roe cured is bought from the poachers at a high price, and every pound of that roe represents several thousand eggs, that, but for the deadly leister of the black-fisher, might have helped to stock the border streams with salmon. We trust the exertions of our excellent crony Mr. Mitchell, the active and energetic Superintendent of the Tweed Police, will year-by-year diminish this disgraceful traffic; and probably it may by-and-by enter his head to strike, as we have no doubt he could legally do, at those who tempt the poachers by paying them $2 \mathrm{~s}$. or $2 \mathrm{~s} .6 \mathrm{~d}$. a pound for the fresh roe. He can seize a carrier's cart during close-time, if but a single salmon is found in it, and fine the carrier; he can follow foul salmon to the uttermost ends of the kingdom, and compel the person in whose possession they are to prove that they were not killed in the Tweed betwen the 15th of October and the 1st of March, or undergo a penalty:-why, then, can he not make a descent upon a vender of salmon-roe, and put him to the same proof as to how and where the article was procured? If he can, sans cercmonie, lay hold of the sides of a "kipper" hanging 
in the cottage chimney, can he not also lay hold of the roe that was once between those sides? At any rate the attempt might have a salutary effect; and possibly. even, it might be found that a water-bailiff is entitled to carry off from under the nose of the angler the pot of roe he is fishing with, and for which, like an ass, he had paid at the rate of 10 s. per pound.

Apropos of bailiffs and penalties, we may conclude this chapter with a word of caution to anglers inexperienced on the borders. In the spring, on the Tweed and most of its tributaries, the angler, while fishing for trouts, may happen to catch something else, which may turn out a Tartar. Bull-trout kelts will very readily, and salmon and grilse kelts will occasionally, take the ordinary flies and baits of the trout-fisher. Hitherto there has been nobody to meddle with him in such case, save perhaps the keeper of the salmon-proprietor (who might not be very difficult to mollify), as there has been no law against the killing of these fish. But, under the amended Act, the murder of a kelt is now a punishable offence; and, should the angler hook one, he must return it to the water as little harmed as possible. Then, before the kelts are fairly out of the rivers. the smolts make their appearance in them. About the beginning of April, the parr assumes silvery scales, is denominated a "smout," and is taken under the protection of the police. (Why the poor parr should have been left friendless during the first year, or, it may be, two years of its existence, we do not know, although we are hardly disposed to suggest an extension of the bailiff's sympathies to it.) From that time 
to about the end of May, shoal after shoal of fry pass downwards to the sea, and it is frequently difficult to throw a fly into the water without hooking a smolt. They may be killed by the dozen by any one who can cast a line. But let none of our readers be tempted to drop them into his basket, instead of throwing them back into the water. A friendly individual will byand-by come up to him, and, after a sensible remark or two about the weather and the water, will ask what sport he has had, and peep into his creel. The Philistines are upon thee! and thou art liable to a fine. Avoid the places, therefore, where smolts are numerous -(they generally congregate in the shallow streams)or fish with worm, minnow, or creeper. The salmonsmolt has blackish fins, and the bull-trout smolt, which, singularly enough, is considerably larger, has bright orange fins, and both may be readily recognised by the ignoramus by the greenish-olive shade on the back, and the bright loose scales that stick to hands, clothes, rod, or whatever else they come in contact with, and thus guide the knowing bailiff.

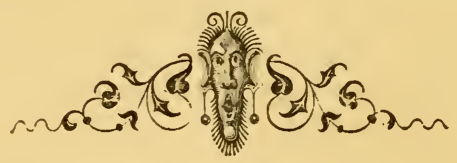




\section{( 45$)$}

\section{CHA P TER III.}

\section{THE TWEED.}

G HAT the Rhine is to the German, or the 14 Jordan was to the Jew, the Tweed is to the Scot. The barrier of his nationality, entwined with his history and traditions, flowing through his songs and beautifying his legends, it is the stream which he is proud of above all others, deficient as it may be in many respects when compared with some native rivers-wanting the parent lochs and mighty volume of the Tay, the rich windings and the regal associations of the Forth, the romantic linns and teeming commerce of the Clyde. The land through which it flows is dear to him as the scene of his ancient ballads; and it has had its old character revivified and refreshed within the memory of the present generation in a way that has made it twice classic and doubly hallowed. The great lyrical harvest that was garnered long ago on the Borders has been succeeded by an after-crop worthy of the first. From source to mouth the Tweed sings for ever to the listener of the greatest of minstrels and romancers, Walter Scott; from the braes of Yarrow and the shaws of Ettrick still comes the sweet and homely strain of the Shepherd-bard ; Teviot rolls in the remembrance of the too brief border-life of John Leyden; while every green glen has, as well as its pleasant water or burnie, its own song and its es- 
pecial poet. And the race that inhabits the land is worthy to inherit such a past. Still, O Tweed-

"Still on thy banks so gaily green, May numerous herds and flocks be seen, And lasses chaunting o'er the pail, And shepherds piping in the dale, And ancient faith that knows no guile, And Industry embrowned with toil, And hearts resolved and hauds prepared The blessings they enjoy to guard:"

But, reverentially as the Tweed is esteemed by the patriot and the poet, what shall we say of the loving regard in which it is held by the angler? Dweller in the cities, what are your thoughts of the Tweed as you bend over your desk, the fishing-rod at peace in a safe corner of your room at home-the creel hanging empty and idle in the back kitchen? The west wind is "blawin' saft amang the leafy trees;" the day before yesterday the surcharged clouds which it had brought from the Atlantic saturated the hills and dales of the South; imagination pictures to you innumerable favourite spots where the brown water is now dimpled by yellow-finned giants: who shall measure your longings? There are thoughts that lie too deep for ink. So, to avoid metaphysics, let us take some facts from Mr. Stoddart, whom we will back against any man in Roxburghshire to give his facts (when he likes) a metaphysical hue:- "The whole" (of the Tweed) he say's, "is planned according to an angler's taste, every inch of water accessible to the wader, without danger or interruption. Its banks, also, are in keeping with its other advantages-not naked and barren, neither 
spongy and overgrown with rushes, nor yet crowded with close and impervious wood, but mostly dry and inviting, fringed in many parts with oak, ash, elm, and beech, and in others hung over with the pleasant alder, among the roots of which is often harboured a goodly and well-grown trout, impatient for some dropping fly or incautious worm. Most to our favour, however, is its choice formation of bottom or channel, fertile in food, provided with shelter, and admirably fitted to the purpose of spawning." How many thousands would add their affidavit to Mr. Thomas Todd Stoddart's panegyric !

Although it is only some six or seven miles above the Crook, we have never beheld the green well-eye-in the side of the same hill that gives birth to the Clyde and the Annan-from which issues the infant Tweed. We the less regret this, however, since, in looking up exact information on the subject, we have discovered a joke, or rather a mild approach to one, in the Statistical Account of Scotland. "It may with truth be said," remarks the reverend anthor of the account of the parish of Tweedsmuir, "that thongh the origin of the Tweed be humble, it is not lowly, as the spring whence it flows is fully 1500 feet above the sea's level." To make this descent-to stray from Erickstane-brae with willing sport to the wild ocean-the Tweed has to run a course of fully a hundred miles. What angler could not follow it lovingly, and, like Violet,

"Be as patient as the gentle stream, And make a pastime of each weary step, Till the last step hath brought him to"-

Berwick, where he would have to take off his trout -flies, 
and start fishing for podlies, coal-saiths, eels, and rockcodlings.

The railway-system which has opened out so much water to the angler has had the effect, however, of making the Tweed, for the first fifteen miles of its course, less accessible than it was ten years ago. The opening of the Caledonian Railway has laid off the Edinburgh and Dumfries Coach, which used to strike the valley of the Tweed at Rachan Mill, and only leave Tweeddale as it turned over the shoulder of the hill into Annandale. Two most convenient anglinginns, Rachan Mill and the Crook, the one about twelve and the other about seven miles from the source of the Tweed, are thus rendered somewhat difficult of access. During some seasons a coach has been run by Mr. Croall to Broughton, but this, we fear, is not likely to last. A line of railway has been projectedthe project is indeed an old one-from the North British at Galashiels to the Caledonian at Symington, and if it is carried out it will throw open many miles of water that are now only attainable from Peebles; but in the meantime, perhaps the easiest way of getting to the head of the Tweed is by the Caledonian to Symington Station, and thence by omnibus to Biggar. The angler who leaves Edinburgh by the first train will get to Biggar shortly after nine o'clock. He is here about twelve miles from the Crook inn, and he may easily accomplish that distance in a day, angling his way down Biggar water to the bridge at Kilbucho Kirk, and thence taking the road across by Rachan Mill to the nearest point of the Tweed, from which he may fisb up to the Crook. Stationed here, he has the 
command of the Tweed and its highest feeders, all of which swarm with trout. Every dimple in the green pastoral hills which form so beautiful a feature in the scenery of these districts is traversed by rill, burn, or "water." For the first few miles the Tweed itself is of course but a brook; the accession of the Fruid and the Tala elevate it to the dignity of a "water;" but it is perhaps not until it receives Biggar-water that it can fairly be called a river. We should not recommend the angler to betake himself to the Crook-or indeed to any hilly region-in the early spring. Trout are there late in getting into condition, the low temperature retarding the development of the insect-world which is to feed them up and restore the flesh they have lost during the season of spawning and hunger. They may be taken readily enough soon after the snows have disappeared from the White Coomb and Culter Fell-or even though the hills are capped with white, if they are "green below the knee"; but they are still poor and spiritless, and we would let the smiles and (often cold) tears of April be nearly over, before visiting the head of Tweeddale. By that time the resident in Edinburgh will be snuffing up daily the east wind in the most dissatisfied way, and he will all the more enjoy the snug shelter of the Crook, and the sunny uplands of Tweedsmuir, where the prevailing winds are from the soft south and west. He may then stretch himself by the linns of Tala without fear of rheumatism, and think of the days when the persecuted people took refuge there amongst the rocks-he may splash throngh the water without wading-boots, 
nor fear to venture over the moss-hags in search of Gameshope Loch or Loch Skene.

The trout of hill-burns are always black in colour and poor in condition; but are also ravenous and easily caught, if the angler only keeps out of sight. What are properly hill-burns are too narrow for flyfishing, and can only be fished by dropping a worm into them over a heather-bush. Uncomely are the inhabitants of these waters, and seldom of large size, but they are numerous and unsuspicious. Indeed, wherever water flows in Scotland, it may be predicated that there are trout. We have picked them out of mere holes in moors and hill-sides that had no visible communication with any stream, the water from them percolating through the peat-moss. Of course there would be a run of water there after heavy rain; and during these temporary floods trout would ascend into the isolated pools, leading hermit lives until another spate gave them an opportunity of returning if they chose to the haunts of their species. We can hardly commend the sport usually obtainable in hill-burns, although, when the water is coloured, large quantities may readily be taken in the most unlikely places. It is amusing enough, however, for the passing angler to devote an hour occasionally to pulling out caricatures of the trutta race-all head and teeth-who voraciously dash at everything that falls into the water, and instantly dart back with it to their secure holds under the bank, from which they often can only be drawn out by taking hold of the line, and giving a straight steady pull. When a burn becomes broad enough for casting with the fly, the trout will be found improved in condition; 
and in many such small streams which flow through meadows and rich soil, they are finer in flesh and colour than in large rivers. These, however, are seldom placed high up amongst the hills, and the trout of the young Tweed and its first feeders are more distinguished for their extent and strength of jaw than for their edible qualities. Of course, they gradually get better as the river widens. The first burn which joins the Tweed is the Core, which might dispute with the Tweed the paternity of the river. Fruid-water, or burn, is the next. It is larger, and is worth fishing in the autumnal season when trout are difficult to be procured in larger waters. The Minzion-burn comes next, and then the Tala, a water well worth the acquaintance of the angler. It has two sources-one the Tala-proper, and the other Gameshope Loch, a small sheet of water that will be best attained by fishing up the Tala, and then striking up the Gameshopeburn, which joins the Tala about four miles from the Tweed, and within sight of Tala linns. There are plenty of trout in Gameshope loch, and the visitor at the Crook should certainly devote one day to the Tala and it. (We would fain quote Professor Wilson's characteristic sketch of a bathing-scene in the Tala, but must refer our readers to the article "Streams"-of which he was proud-which contains a panegyric on the Crook, and has been republished in his Miscellanies.) All the streams which we have yet named flow from the south, and are above the Crook, and by their united contributions the Tweed at that place becomes a most pleasant and convenient angling stream. Abounding in trout, with fine alternations of stream 
and pool, the angler may command every inch of it without wading. As the Tweed is accessible to the salmon to its very source, the shoals of parr that exist in all these streams indicate that the salar and eriox pay their winter visits to the hills, and do their part in the great economy of nature in multiplication and the replenishing of the waters. Few of the sea-fish, however, ever get back, for the shepherds of Tweedsmuir are sad poachers, and the sight of a salmon within reach of the leister is what no Scotchman can well resist.

So having spent the half of his holiday-week at the Crook, let the angler next fish quietly down to Rachan Mill, looking up Kingledoor's-burn on his left hand for a mile, just to see it, on his way, and passing by Stanhope-burn on the other side, which is preserved (!!) by Sir Graham Montgomery, and is therefore so much fished as not to be worth attention. The angler will see other rivulets on his way down-Glenriska, Harestane, and Polmood; but they are only for exceptional occasions, such as heavy floods, when larger streams are unfishable, or for the month of August, when trout, in all but small burns, where their hunger is chronic, seem palled, and trying like overfed aldermen to recover the tone of their stomachs by fasting. Stationed at Rachan Mill, he has command of Biggar-water and Holms-water (a tributary of the former), and of a burn which comes in from Drumelzier. Biggar-water is one of those to which we have alluded as flowing through a rich allnvial soil, and productive of trout of superior size and quality. It is the only stream in Peebles-shire the trout of which are red- 
fleshed. Salmon follow it up for only a few miles, for when "the monarch of the tide" enters the fresh water, he is on the outlook for gravel-beds, and does not care for rich feeding. We believe, however, that the best part of Biggar-water has been spoilt by a practice that has become too prevalent-that of straightening watercourses, in order to gain meadow-land, and to guard against overflows. Probably, however, a delicate flyfisher or a dexterous spinner of the minnow will yet he rewarded for a little patience and effort in a water that had so high a character. Holms-water takes its rise behind Culter-fell, on the borders of Lanarkshire, and flows through a delightfully pastoral vale. It will well repay half a summer's-day with the worm. Broughtonburn and Kilbucho-burn are also within reach from Rachan Mill, and there are inns at both Broughton and Kilbucho, at which the accommodation is, we believe, excellent.

Here let us, before rejoining the Tweed, state a rule which we believe will very generally be found to hold good in respect to fishing in burns. For the first halfmile or so from their confluence with the main stream they seldom contain many trout. We can only account for this by supposing that the trout which run up them from the larger streams during floods, and which chiefly stock these burns, do not stop until they have gone some distance. It is so with the Tweed itself, as regards salmon; for there are seldom, except after long droughts, fish lying in the river within several miles of the sea. The burn-angler, therefore, would do well not to be discouraged if he should meet with but little success at first, even in likely pools; 
and he might generally with safety miss the first few hundred yards altogether.

The last day of his week has now come, and the angler must be up betimes, for we propose that he shall return to Edinburgh by way of Peebles, and that ancient town is eleven miles off, with some tempting water between. In summer-time, the angler cannot be too soon at his sport, and, if he is fishing down the water, probably the first two or three hours of the morning with the minnow will be the most productive of the whole day. The course of the Tweed is no longer through a vale between ranges of steep green hills, but it now makes its way throngh a more level country, and here and there its banks are wooded and picturesque. It is still a most satisfactory stream to fish; the trout are plentiful, and easily reached.

"There 's no a hole aboon the Crook,

Nor stane or gentle swirl aneatl,

Nor drumlie rill nor faery brook,

That daunders through the flowery heath,

But ye may fin' a subtle trout,

A' gleaming ower wi' starn and bead,

And mony a sawmon sooms aboot,

Below the bields o' bonnie Tweed."

We are not yet, however, in the region of the salmon. Though the streams swarm with foul fish in the spawning season, it is probably some years since a clean salmon has been caught above Peebles, and we can only hope for better things in future under the new dispensation of 1857. The trout, however, are larger between the mouth of Biggar-water and Peebles, than in any of the upper streams except Biggar-water itself, in which fish of several pounds in weight have been 
caught. The pannier is now likely to contain, by the evening, a trout or two of a pound weight, and several of three-quarters and half-a-pound.

Tweed having escaped from the hills, there are now fewer feeders, and indeed, throughout the whole of the rest of the Tweed there are very few burus which communicate directly with the main river. Their tribute gathered from the high lands is brought in at second-hand by streams which almost rival the Tweed itself in size. We observe a burn with the name of Weston Burn, marked on the map as flowing through the parish of Stobo to the Tweed, but can say nothing of its angling capabilities. About three miles above Peebles, however, the Tweed receives the Lyne, a stream which takes it rise on the south side of the Pentlands, and has a course of about fifteen miles. The lower part of the Lyne may be fished from Peebles, and the upper part, and its tributary the Tarth, from Romanno Bridge, which used to be one of the stations of the Edinburgh and Dumfries Coach. The Lyne is noted for the number of trout which it contains, and was a favourite resort of Edinburgh anglers in the coaching days. It is still worth a visit-probably the more so, that there must be fewer anglers in it now than formerly. The Tarth, like many other streams, is said to have been injured of late by having its banks cut and straightened.

IVe have, however, still charge of the angler who started with us for a week's fishing in Upper Tweeddale; but he has now made his way to Peebles from Rachan Mill. He had to take provender in his pocket, for there is no baiting place by the water-side. He 
is bound for Edinburgh by the evening train, and we have now time to look about us at the place and its scenery, as well as at the fishing for which Peebles furnishes a convenient station.

Peebles is a curious old Scotch burgh, supposed from its name to have been a haunt of the nomadic Britons who long held Ettrick and Strath-Cluyd. It obtained a royal charter from David II. in 1337, but was ruthlessly deprived of the parliamentary privileges thereto effeiring by the Reform Act of 1832 . It has still a provost and council, and is the county-town. It has throughout borne the usual character of small Scotch towns, having always been a homely, drouthy, God-fearing place. Its inhabitants, of whom there are about 2000 , and who are as "clannish" as the inhabitants of other Scotch towns, consider it the most remarkable spot in the universe. It is looked upon as a metropolis by the surrounding country districts, and a story is told of a county-laird, who thus gave his verdict as to the comparative merits of this capital and that of France-"Paris for pleesure!-Hoot-toot! gie's Peebles!" It is, however, prettily situated, and is singularly healthy. The bare pastoral hills of Tweeddale are here partly relieved by wood; Nidpath Castle, about a mile above the town, overhangs the Tweed, there contracted in its vale to a deep glen; at Peebles itself two bridges span the river; and below, the eye follows an opening valley, with the ever-charming accompaniments of adjacent wonds and a stately stream. Nidpath Castle is a strong old tower, once belonging to the Earls of Tweeddale, and some pretty 
as well as warlike legends are connected with it. It was formerly surrounded by fine woods, but when the ownership of it passed to the wretched old voluptuary, the last Duke of Queensberry, who was so long a scandal to the nobility of Britain, he felled the aged trees, and let the castle sink into decay. Wordsworth, in an indignant sonnet, has denounced the "degenerate Douglas" who was guilty of this disgraceful treason to his lineage and his country. 'The castle has since, as the property of the late and of the present Earl of Wemyss, been merely the residence of a gamekeeper, and has been falling more and more into ruin; but we have heard with pleasure that Lord Elcho, whose patriotism and fine taste are so well known, has lately taken steps for its preservation, if not for its partial restoration.

Manor-water joins the Tweed, from the south, about two miles above Peebles. The Manor flows through a quiet hilly glen, and is a capital stream for trout. It is stated that at one time netters ravaged its waters, sending the spoil to Edinburgh by the carriers; but we believe Lord Minto's Act has had a deterrent effect, and we have heard of excellent sport being obtained in it of late years. If the pedestrian angler wants to take Peebles on his way to St. Mary's Loch-and the way by Peebles is indeed the most convenient-he must follow up the Manor to its source by a road that, at first passable for carriages, turns by-aucl-by into a mere foot-path, seeming indeed to be finally quite stopped by the Bitch-crag. No angler could well walk the twelve or thirteen miles of Manor-glen withont trying a cast in some of the tempting pools and streams, 
and, if there is a slight flood, he will generally be well rewarded.

Eddleston-water enters the Tweed just at Peebles, separating indeed the old from the new part of the town. The Peebles railway joins the vale through which the Eddleston flows about seven miles from Peebles, and follows it down to the ancient burgh, where railway and stream both terminate. The upper part of the Eddleston owns the sway of Mr. William Forbes Mackenzie of Portmore, but we are not aware that he has made any attempts to impose restrictions upon the angler's traffic in it. It is below Portmore, however, that the best fishing is to be had, and the angler may either get out at Eddleston station and fish down (about five miles) to Peebles, or may go to Peebles and fish back to Eddlestone. If he is using minnow, or if the water is coloured, the former would be the better course; if the water is clear, and he is fishing with fly or worm, we should recommend the latter.

Peebles is a highly eligible station for the angler. The arms of the burgh are three salmon, but, like the pretensions of the town itself, these are emblematic rather of the traditional past than of the actual present. In the last generation some of the best and most successful salmon-fishers of the Tweed were burghers of Peebles, but probably not. one of their successors can boast the capture of a clean salmon per annum for twenty years past. Now that kelt-killing is abolished, the occupation of the Peebles salmon-fishers is gone, unless an occasional clean fish or two should in future be permitted to make their way so far up. The Peebles 
bodies, however, are shocking poachers, and we should imagine the Tweed bailiffs would like to have an Aladdin's lamp to shift the town to some other quarter of the globe during the winter season. At this point the Tweed is in every way adapted for all kinds of poaching implements-straik-net, cairn-net, rod, leister, and cleek, can all be used with the most murderous effect. In the district of which Peebles is the head-quarters, many hundreds, probably thousands, of spawning salmon and foul fish were last year killed. As respects trout-fishing, perhaps the chief drawback to Peebles is the expertness of the inhabitants themselves in the art. Some of the adepts of the town would be "bad to beat," and they are much addicted to fishing, know the water of course thoroughly, and even a good angler may chance to find himself obliged to sing very small when baskets come to be compared by the river side, or to be talked of in the evening at the Tontine. Besides the Tweed, the waters commanded from Peebles are the Lyne, the Manor, and the Eddlestone, which have already been noticed, and several burns, like that at Hayston, which would probably"repay examination. There are excellent hotels at Peebles, of which the Tontine is the chief, but in the Commercial, the Crown, and the Cross-Keys, all the accommodation that an angler or a traveller may want can be obtained. For those disposed to make a stay there are plenty of lodgings.

Innerleithen, popularly believed to be the St. Ronan's of Sir Walter Scott's novel, is six miles below Peebles, a convenient distance for a day's angling, or it may be reached by an omnibus which runs between it and the 
Peebles railway-station. It possesses a spa-well, and is a delightful summer resort for invalids. The invalid angler could hardly, indeed, desire a more suitable retreat. There is medicinal water if he wants it, quiet and charming scenery, the Tweed, the Leithen, and the Quair, for the exercise of his rod. We would hardly, however, recommend it to the angler who is in good health. Innerleithen is a manufacturing village as well as a watering-place, and its inhabitants are not only inveterate anglers, but we fear we must add inveterate netters. There are about five miles of excellent fishing-water in the Tweed between Peebles and Innerleithen, but for a mile or two on each side of the latter place, the trouts are not very numerous, and besides have far too much experience and knowledge of gut and feathers to be very easily enticed. Still the skilful angler may overcome these drawbacks - so much the more does he deserve honour; but as a rule, we should recommend him to avoid wateringplaces, and for ourselves personally we would rather, while angling, cultivate the society of the lower orders of creation, than even of "man made in God's image," especially when he is in the shape of a cockney with a rod in his hand who has gone splashing down a stream before us. It is an illustration, however, of the beneficent fitnesses of things that pervade the universe, that your cockney seldom or never fishes in a burn, and seems satisfied with any sheet of water in which he can exercise his dexterity in casting with a final result of " half a brace of trout."

The Leithen is just between a "water" and a burn, contains lots of trout, and great quantities may be 
taken in it, as well as in the burns and rills which feer it after a flood. The Quair, which makes its way to the Tweed on the other side, through the fine woods in which Traquair House, the seat of the Earl of Traquair, is embosomed, is, we believe, partly preserved, but the npper parts of this pretty streamlet, as well as its feeders, are open, and offer a pleasing variety to Piscator after he has had his morning draught at the Spa. Up the Quair there is a road to the vale of Yarrow, accessible to vehicles, and a pleasanter drive than from Innerleithen to St. Mary's Loch, first through fine woods and then through the pastoral treeless "forest" could not well be desired. The "bush aboon Traquair," which, like "the broom o' the Cowdenknowes" and Polwarth green, is a landmark in border song, is pointed out as represented by some birch trees on a little eminence overlooking the valley above Traquair House. We are told his Lordship carefully preserves these interesting relics. Lord Traquair, who is a very old man, has, for some reason or other, been greatly opposed to the protection of the Tweed; so much so, that the bailiffs were not allowed to be lodged in any house on his property. As he is the proprietor of Innerleithen, and of the adjoining parts of the river, which has since the erection of woollen factories at that place been daringly poached, this was a matter of great inconvenience until the bailiffs got an iron house made, which they have erected, we believe, at the nearest suitable point. Perhaps, as his Lordship is a remarkably rigid Roman Catholic, he was afraid that the humbler adherents of his creed might, if poaching were strictly repressed, find some difficulty 
in obtaining fish for dinner "on Fridays when they fastit."

Below Innerleithen the valley of the Tweed for a few miles preserves an intermediate character between the pastoral hills and glens in which-it begins, and the rich and woody lowlands to which it tends and in - which it ends. Holylee on the north side, and "Elibanks and Elibraes," Ashestiel, and Yair House, on the sonth, are so beautifully situated as to be of themselves sights worth a walk down Tweedside from Innerleithen. To the trout-angler, there is here a stretch of eight or ten miles of water scarcely surpassed on the Tweed. Rippling streams and pleasant pools, swarming with trout of superior size, distinguish this part of the river, and careful fishing will invariably produce excellent results. As Stoddart sings-

" Frae Holylee to Clovenford,

A chancier bit ye canna hae;

So, gin ye tak an angler's word,

Ye'd through the whuns and ower the brae,

And work awa wi' curnin' hand,

Yer birzy hackles, black and reid :

The saft sugh o' a slender wand

Is meetest music for the Tweed."

We ought, perhaps, to remark that the "up-stream" rule of fly-fishing ought not to be too pedantically adhered to in the Tweed, after it has become a broad and deep river such as it is here and for the rest of its course. Mr. Stewart himself confesses that that mode of casting is best adapted for smaller waters which are easily commanded, and it is clear that wading up a strong stream for a whole day would be heavy work. Besides, there are deadly places just where a heavy 
stream loses itself in a deep pool, which can only be reached by a long cast across and downwards, after the angler has waded as far as he can with safety. Here large trout feed, especially in the earlier part of the season, before they have begun freely to enter the rapid and shallow water. Indeed the very largest trout of all, perhaps, never come fairly into the shallows except at night, and if the angler wants a threepounder, he must try for it with fly or minnow in some such place as we have described.

Trout-flies for the Tweed, too, beneficially admit of greater variety, and of more fanciful combinations of colour, than those employed in its tributaries. For instance, a "drake-wing" - that is, a fly with the wing formed from the black and white barred feather of the teal or wild drake-is not, according to our experience, a very telling fly in small waters, but in the Tweed we have often found it the very best that could be used, and always found it doing a fair share of work. Indeed, several years ago, when angling in the Tweed pretty constantly, we entertained so high an opinion of the merits of the drake as generally to use it as the tail-fly. It may be dressed with either a black or a red hackle-very slight-and may be used, according to season or the state of the water, of all sizes, from the whitling-fly down to the midge. In coloured water, the "Professor" - an invention of Professor Wilson'swhich is the drake wing and hackle with a body formed of orange-silk, is very effective in the Tweed.

This part of the Tweed used to attract many anglers to the inn at Clovenfurd, on Caddon-water (which joins the Tweed about a mile below Ashiesteel) before 
the railway to Hawick superseded the coach that ran past it between Edinburgh and Carlisle. It is about a couple of miles from the Tweed, and still the best station for fishing this part of the river. Caddonwater itself is worth the angler's attention, especially in exceptional states of water when the Tweed is unfishable. After rain, smaller waters are often falling into the best condition for angling just when the main river is rising to its height, and a minnow or worm may be deadly in the Caddon when the Tweed is roaring from bank to brae, and the sickened and terrified trouts are thinking only of their safety as they keep to the edge of the yellow flood that is covering haugh and holm. Clovenford is about three miles from Galashiels.

Salmon-fishing may be said to begin at Holylee, a number of grilse, and a clean salmon or two, being usually captured by the rod so far up every season. The Yair fishing-water, which is next to this, and extends a distance of about four miles from Thornylee to Yair Bridge, is even let to a large party of Edinburgh anglers, who have a snug shieling on the waterside at "The Nest," near Fairnilee, capable of accommodating, at a pinch, nearly a dozen. They are said to be jovial fellows, and to enjoy themselves remarkably in their excursions to Tweedside. We believe they pay about $£ 70$ per annum for the water, and have, in addition to the salmon-fishings, a right of shooting over some ground in the neighbourhood. Hitherto they have slain more kelts than clean salmon, however, only a very favourable flood ever bringing either the latter or any considerable number of grilse into their water. Mr. Russel of the Scotsman, a rather celebrated angler, 
to whom we have already referred in connection with the new Tweed Act, is one of them, and gave in evidence to the House of Commons Committee that "at the beginning of the season in 1856 he killed nine salmon (kelts, we presume) in one day, whereas during the rest of the season, though out eight or ten times, he got only one." He stated, indeed, that he had made calculations in 1850 which led him to believe that in that year there had not been more than 700 clean fish altogether killed by the rod in the Tweed. A few grilse and salmon-the latter perhaps not particularly clean-have, however, always been got by "The Nest" anglers in the period of grace allowed for rodfishing at the end of the season, and it is hoped that, in future, although the time is abridged, the sport will be better.

As we have reached the salmon-district of the Tweed, we are now also fairly into the land of Scott. At Ashiesteel he took up his residence after being appointed Sheriff-depute of Selkirk, when his principal began to grumble about his living at Lasswade, at a distance from the scene of his duties. Here he wrote the Lay, Marmion, Waverley, and others of his immortal works, and abode until he became the laird of Clartyhole, and built his "stone and lime romance" at Abbotsford. He was the plain "Shirra,"-not even the titular "Duke of Darnick" - and was ready for any kind of "ploy." He was an angler, although he declares in bis review of Sir Humphrey Davy's Salmonia, that his line usually fell "with the emphasis of a quoit;" and Hogg talks of him as being in his highest glee when "toiling in Tweed to the waist" with rod or 
leister. Jamie relates of him, while he lived at Ashiesteel-

"He and Skene of Rubislaw and I were out one night, about midnight, leistering kippers in Tweed, and on going to kindle a light at the Elibank March, we found, to our inexpressible grief, that our coal had gone out. To think of giving up our sport was out of the question; so we had no other shift save to send Rob Fletcher home, all the way through the darkness, the distance of two miles, for another fiery peat.

"While Fletcher was absent, we three sat down on a piece of beautiful greensward, on the brink of the river, and Scott desired me to sing him my ballad of Gilmanscleugh. Now, be it remembered, that this ballad had never been either printed or penned. I had merely composed it by rote, and on finishing it, three years before, I had sung it orer to Sir Walter. I began it at his request, but at the eighth or ninth verse I stuck it, and could not get on with another line; on which he began it a second time, and recited it every word from beginning to end. It being a very long ballad, consisting of eighty-eight verses, I testified my astonishment

"Rob Fletcher came at last, and Mr. Laidlaw of Peel with him, and into the foaming river we plunged, in our frail bark, with a blazing light. In a few minutes we came into Gliddy's Weal, the deepest pool in Tweed, when we perceired that our boat gave evident symptoms of sinking. When Scott saw the terror Peel was in, he laughed till the tears blinded his eyes. Always, the more mischief, the better sport for him. 'For God's sake, push her to the side !' roared Peel. 'Oh, she goes fine,' said Scoft ; 'An' gin the boat were bottomless, an' seven miles to row;' and, by the time he had well got out the words, down she went to the bottom, plunging us all into Tweed over head and ears. It was no sport to me at all; but that was a glorious night for Sir Walter, and the next day he was no worse."

Scott was not Shakespeare,-but who, of these latter days, has had more of Shakspeare's genius and spirit? If he had been born at Stratford-upon-Avon some three 
hundred years ago, who can doubt but he would have drawn a poaching cross-bow in immortal company in Charlcote park, and taken his full share in a memorable ale-drinking match in the neighbouring village, from which the young men of Stratford walked off victorious, but had to succumb before they reached home, and sleep all night under the hedge?

In 1812 Sir Walter had finished Abbotsford, which is about six miles below Ashiesteel on the Tweed, and bade the latter place good-bye, not without a pang. But he was proud of his new creation, and of the title of border-laird which was now his due. Here it was that he lived for a space, deservedly waited upon, if ever man was so, by "honour, love, obedience, troops of friends;" hither, after the crash of his fortunes and the death of his wife, he fled when he could from his duties in Edinburgh, and toiled to redeem his position and his credit, until his wonderful brain gave way; hither, from the blue skies of Italy, he was driven by the yearnings of his love for his native country to die. Lockhart draws a delightful picture of the life at Abbotsford in 1820 :-

"It was a clear, bright, September morning, with a sharpness in the air that doubled the animating influence of the sunshine, and all was in readiness for a general coursing-mateh on Nerark Hill. The only guest who had chalked out other sport for himself was the staunchest of anglers, Mr. Rose ; but he too was there on his shelty, and with his salmon-rod and landing-net, and attended by his humourous squire Hinves and Charlie Purdie, a brother of Tom, in those days the most celebrated fishermen of the district. This little group of Waltonians, bound for Lord Somerville's preserve, remained lounging about to witness the start of the main cavaleade. Sir Walter, mounted on Sybil, was marshalling the order of procession with 
a large hunting-whip; and, among a dozen frolicsome youths and maidens, who seemed disposed to laugh at all discipline, appeared-each on horseback, each as eager as the youngest horseman in the troop-Sir Humphrey Davy, Dr. Wollaston, and the patriarch of Scottish belles lettres, Henry Mackenzie. The Man of Feeling, however, was persuaded with some difficulty to resign his steed for the present to his faithful negro follower, and join Lady Scott in the "Sociable," until we should reach the ground of our battue. Laidlaw on a long-tailed wiry highlander, yclept Hodden Grey, which carried him nimbly and stoutly, although his heel almost touched the ground as he sat, was the adjutant. But the most picturesque figure was the illustrious inventor of the safety-lamp. He had come for his favourite sport of angling, and had been practising it successfully with Ross, his travelling companion, for two or three days preceding this, but he had not prepared for coursingfields, or had left Charlie Purdie's troop for Sir Walter's on a sudden thought; and his fisherman's costume, a brown hat with flexible brims, surrounded with line upon line of catgut [catgut !] and innumerable flyhooks, jackboots worthy of a Dutch smuggler, and a fustian jacket dabbled with the blood of salmon, made a fine contrast with the smart jackets, white cord breeches, and well polished jockey boots of the less distinguished cavaliers about him. Dr. Wollaston was in black, and with his noble severe dignity of countenance, might have passed for a sporting archbishop. Mr. Mackenzie, at this time in the 76 th year of his age, with a white hat turned up with grreen, green spectacles, green jacket, and long brown leathern gaiters buttoned up on his nether anatomy, wore a dog-whistle round his neck, and had all over the air of as resolute a devotee as the gay captain of Huntly Burn. Tom Purdie and his subalterns had preceded us by a few hours with all the greyhounds that could be collected at Abbotsford, Darnick, and Melrose; but the giant Maida had remaincd as his master's orderly, and now gambolled about Sybil Grey, barking for mere joy like a spaniel puppy."

Lockhart's substitution of catgut for the fine entrail of the Spanish silk-worm-as if Sir Humphrey had 
been a fiddler instead of a fisher-is the less pardonable as, besides being Scott's son-in-law, and an occasional angler himself, he was the constant associate of the Wilsons, Hogg, and others of the keenest anglers in all Scotland. Old people in the district yet remember the sports at this period,- - the great annual hunt, when all the neighbouring farmers attended, and the proceedings terminated in a grand dinner and drinkingbout, Sir Walter in the chair-the gala fishing days at Charlie Purdie's at Boldside, \&c. As a companion picture to the foregoing-but in melancholy contrast to it-let us extract Lockhart's account of the last sad home-coming of the great Magician of the Tweed. No borderer will "lay his banes far frae the Tweed," if he can help it, and Sir Walter Scott felt at Naples that he could not die away from Abbotsford. He came back to London, and, although almost bereft of thought and consciousness, still longed for his border-home, and was brought to Edinburgh. Few Scotsmen, we fancy, can read the narrative of his final journey to abbotsford through familiar scenes, without an uncomfortable sensation about the eyes:-

"At a very early hour on the morning of Wednesday the 11 th, we again placed him in his carriage, and he lay in the same torpid state during the first two stages on the road to Tweedside. But as we deseended the vale of the Gala he began to gaze about him, and by degrees it was obvious that he was recognising the features of that familiar landscape. Presently he murmured a name or two- 'Gala-water, surely-Buckholm -Torwoodlee.' As we rounded the hill at Ladhope, and the outline of the Eildons burst on him, he became greatly excited; and when turning himself on the couch his eye eaught at length his own towers at the distance of a mile, he sprang up with a ery of delight. The river being in flood, we had to go round 
a few miles by Melrose Bridge, and during the time this occupied, his woods and house being within prospect, it required occasionally both Dr. Watson's strength and mine, in addition to Nicolson's, to keep him in the carriage. After passing the bridge, the road for a couple of miles loses sight of Abbotsford, and he relapsed into his stupor; but on gaining the bank immediately above it, his excitement again became ungovernable.

" Mr. Laidlaw was waiting at the porch, and assisted us in lifting him in. He sat bewildered for a few moments, and then resting his eye on Jaidlaw, said, 'Ha ! Willie Laidlaw!-O man, how often have I thought of you !' By this time his dogs had assembled about his chair-they began to fawn upon him and lick his hand, and he alternately sobbed and smiled over them until sleep oppressed him."

He died on the 21st of September 1832, and five days afterwards a stream of mourners followed his body across the Tweed and over the hill of Bemerside to Dryburgh. Wordsworth thus fitly lamented him-

"A trouble, not of clouds or weeping rain,

Nor of the setting sun's pathetic light

Engender'd, hangs o'er Eildon's triple height;

Spirits of Power, assembled there, complain

For kindred power departed from their sight,

While Tweed, best pleased in chaunting a blithe strain,

Saddens his voice again and yet again."

We shall not encroach upon the domains of our brother inditers of guide-books by giving the oft-repeated descriptions of the curiosities that may be seen at Abbotsford. But the house may be visited, and a few hours' good angling at the same time be obtained, in a single day from Edinburgh. Leaving Edinburgh by the first train, and taking the Selkirk train from Galashiels, the angler will be set down at Boldside, close by Abbotsford, a little after nine o'clock, with nine hours before 
him for visiting the shrine and trying his skill in the Abbot's ford, before the return train is due. He may either fish up to Ettrick foot and back, or down to Melrose, a distance of about three miles by the water, where he may catch the evening train.

The Ettrick is the first of the larger tributaries which the Tweed receives, and it enters the main river about three miles below Yair-bridge. We reserve it and the Yarrow, however, for a future chapter. From Ettrickfoot to Melrose the salmon-fishings belong chiefly to Major Scott of Gala and Lord Somerville, and we believe the different waters are all rented by Mr. Broadwood, the eminent London piano-manufacturer, who has several keepers protecting the river, and pays a visit or two each year to the Tweed, residing at the Pavilion, Lord Somerville's seat, which he rents along with the fishings. The Gala joins the Tweed from the north, a little below Abbotsford, and about three miles above Melrose. It, also, and the streams that subsequently contribute to the Tweed-the Leader, the Teviot, the Till, and the Whitadder-are of sufficient importance to demand separate notice. The Allan or Ellwand-water, which runs about parallel with the Gala, separated by high ground, flows in a little below the junction of the latter stream. Its vale is the Glendearg of "The Monastery," but we regret that we can say nothing as to its adaptation to angling. Scott thus describes it in the preface to the novel we have mentioned:- "The Allan, after traversing the romantic ravine called the Nameless Dean, thrown off from side to side alternately, like a billiard ball repelled by the sides of the table on which it is played, 
may be traced upwards into a more open country, where the banks retreat farther from each other, and the vale exhibits a good deal of dry ground, which has not been neglected by the active cultivators of the district." Near the mouth of this little stream was the singular old bridge across the Tweed which figures in the same book. It consisted of three stone pillars, or towers, connected by wooden planks; on the middle one the toll-keeper lived, and levied his duties upon those who passed. The trout-fishing in the Tweed here is hardly equal to the average, the weavers of Galashiels being, like all borderers, addicted to "casting angles in the brook," and many of them are no contemptible adepts. A very unwise attempt was a couple of years ago made in the name of Lord Somerville, but really, we believe, by Mir. Broadwood, to stop the public right of angling here; but the Sheriff of Roxburghshire, after two or three contradictory decisions, finally gave it as his opinion that the right of salmon-fishing does not carry with it any exclusive right of trout-fishing.

We are now at Melrose, whose ancient ecclesiastical splendour has been rubbed up of late years by Sir Walter and local antiquaries, after its former inhabitants had been consigned to posterity as luxurious hypocrites in a brave (but coarse) old Reformation song-

" Of Scotland wele the Freiris of Faill,

Their lymmerie lang has lestit;

The monkis of Melross maid gude kale, On Frydays quhen they fastit;"

with certain other particulars of monkish habits which we decline here to recapitulate. Overshadowed by the 
Eildons, and predominating over the broad river, Melrose has been a suitable site for the magnificent Abbey which still, after the fierce ravages of English invarlers and Scotch puritans, and the gnawing of time's ceaseless tooth for two centuries and a half, commands the wonder and admiration of visitors from every part of the world. Dilapidated as it is, it is doubtful if this island has any other specimen of Gothic architecture so grand in conception and yet so delicate in execution. "The slender shafts of shapely stone, by foliaged tracery combined," suggested to Sir Walter Scott the idea that magic art alone could have wrought stone into such forms, or rather that some fairy had twined ozier wands through poplars-

" Then framed a spell when the work was done, And changed the willow wreath to stone."

But everybody has the beautiful and weird scene at Melrose in the "Lay of the Last Minstrel" by heart. Melrose Abbey was fornded by King David in 1136, and it seems to have been built in ten years by a certain John Murvo or Morow, who in a quaint scroll claims to have "had in keping al mason-wark" of numerous other churches in Scotland. It took the place of an older monastic establishment, situated a little further down the river at Old Melrose, whither Christianity was first transplanted to the South of Scotland from Iona, and where St. Cuthbert erewhile led his holy life. Within its precincts lie the ashes of Scottish monarchs, nobles, and holy dignitaries of the old church. The heart of King Robert Bruce, after its singularly romantic conveyance to Spain, on its way to be buried at Jerusalem, was brought back by 
Sir Simon Lockhart, and buried at Melrose. The dead Douglas who won the field of Otterburne was also brought here to be interred-a fact which we rather regret, seeing that while we give implicit credence to the Scottish ballad's account of that battle, as against the English one, we can hardly reconcile this with the distinct statement that "Earl Douglas was buried at the braken bush," where he had given his heroic dying instructions to his "ain dear sister's son, Sir Hugh Montgomerie." "Heir lyis the race of ye Hous of Zair" is one of the striking inscriptions upon the walls of the abbey; and there are many other legends graven about the old walls, which, while they teach the Melrose moralists to die, recall also the pomp and pretensions of Scottish families, many of which are now extinct. The Abbey of Melrose had rich and farspreading possessions in its palmy days, which were bit by bit gripped by greedy barons, and were finally confiscated at the Reformation. It had piscarial rights in the Tweed adjoining, conferred by the charter of David I.

A little rivulet with (as is sometimes the case with Scotch burns) several names, flows into the Tweed through the first haugh above Melrose. It comes from Cauldshiels Loch, on the Abbotsford estate, where Scott and his family used to bob for perch; but it is chiefly remarkable as associated with Thomas the Rhymer,-Huntly bank, where he first saw the Fairy Queen, overlooking it. It is called, we believe, the Bogle-burn, and the Rhymer's-burn.

As we have said, the salmon-fishings in the Tweed, above and at Melrose, belong to Lord Somerville, and 
are rented by Mr. Broadwood. The Cauldpool, and the stream above it, just above the suspension-bridge that has recently been erected for communication with Gattonside-a village on the opposite bank of the Tweed-have several noted casts, and the Battery stream and Cowie's Hole, below the bridge, have also usually a number of grilse in them in summer-time. There is, indeed, excellent salmon-fishing close to Melrose, but of course it is somewhat difficult to obtain permission to try it. A Purdie-a nephew, we believe, of Sir Walter's Tom-is one of Mr. Broadwood's keepers, and inherits much of the spirit of his predecessors.

There is not, however, any restriction now upon fishing for trout-the attempt to prohibit the public right having been abandoned. A stupid decision by Sheriff Rutherfurd (of Roxburghshire) to the effect that the owner of a salmon-cast may prevent troutangling in it, lest the salmon should thereby be disturbed, is, we should think, too absurd for anyone ever to try to enforce it. Melrose, therefore, is a capital station for the angler. He has the Tweed at hand; the railway will, any morning, carry him to any other part of the river below him, to the Gala, to the Teviot, or to Ale-water, and bring him back at night; while he is within walking distance of the Leader and the Elwand. There are excellent inns-in fact, all so good that we cannot single out any as the best, although the George is perhaps the most frequented. A tackle-shop-a branch, if we mistake not, of Forrest's of Kelso-will supply the angler with suitable flies or other angling material, and the intelligent keeper 
thereof will give the best advice and counsel as to what ought to be used.

The salmon-fishings for the next seven or eight miles of the Tweed's course-from Melrose to Dryburgh-belong to a number of different proprietors, and several of them are let to English anglers. There are many excellent casts in them,- - the "waters" getting better and better, as each has of course a better chance of getting a few fish than the one above it. We do not know how, in the absence of personal acquaintance, leave of salmon-fishing may be obtained in these waters - unless from the keepers of the lessees who reside at a distance. Possibly a civil application might frequently be successful; but high rents are given for the waters, and it is hardly to be expected, therefore, that the privilege should go a-begging.

Here, too, there have been some mutterings, we believe, of greedy discontent that the right of angling for trouts should be retained by the public, and some placards have been stuck up threatening the utmost rigour of the law, \&c. As that rigour is not very great, however-at the utmost there could only be an action for trespass, and compensation exacted for damage done-we do not recommend the angler to abstain from choosing what streams he thinks best. He cannot well go wrong, and if, wandering down to about Leader-foot before beginning, he fishes round the pleasant haughs of Old Melrose to Dryburgh bridge, leaving off in time to walk up by St. Boswell's-taking a single dram there-to Newtown station, with ordinary skill he may make sure of a creel-full. If fishing with creeper, may-fly, or with worm in summer-time, 
for which there are capital streams in this stretch of water, he ought to go to Dryburgh-bridge in the morning, and fish up. He must not, as we have said, choose the deep and rapidly flowing streams, but the very shallowest ones he can pick out, or the thin sides of the deeper ones. Hereabouts in the Tweed, and further down, there is always a chance of a whitling or seatrout, and in spring it will frequently happen that the trout-angler may hook a kelt. We have already warned him, however, to return kelts to the water with all possible care.

St. Boswell's, or Lessudden, about five miles from Melrose, is the next station on the Tweed for anglers. It is about two miles from Newtown railway station, where the line branches to Kelso and Hawick, and is itself about a mile from the Tweed. There are two inns, of which the Buccleuch Arms is the principal, although the other is also a snug retreat for the angler. Lessudden is admirably situated for fishing a few miles of the Tweed that are not attainable from either Kelso or Melrose save by railway, and we are sorry to say that convenient trains do not usually run about three or four o'clock in the morning, or about eleven at night-so that when using them, the angler must sacrifice both morning and night, and confine his sport to six or seven hours during the day. We fear much that no representation from the angling community for such suitable trains would be attended to; so that the angler who has a few days' leisure ought to plant himself in such places as stud the banks of Tweed, where the water is at his feet. The Dryburgh and Mertoun fishings-both of a very high character for trout 
and salmon-are close by Lessudden; and, just across the bridge, is Dryburgh Abbey, where the Last Minstrel himself was laid to sleep in 1832, and whither, in 1854, his son-in-law and biographer was brought to be laid beside him. The upper part of the Mertoun fishings is let to an English gentleman, who resides at Lessudden during the grilse season, and has a keeper who watches that particular water during the open season, and, like other keepers, becomes a member of the regular Tweed police during close-time.

We cannot pass Lessudden without a salutation to our venerable friend, Mr. John Younger. John is the village shoemaker, and the pedal encasements which he turns out are worthy of the highest praise. If an angler wants a pair of stout Tweed fishing-boots, or of walking boots to wade in, by themselves or along with waterproof leggings, we should, in all honesty, recommend him to John Younger. He is now old, however -having indeed passed the point fixed by the Psalmist for summing up human existence. He was a militia-man in 1804, when the false alarm of a French invasion spread from beacon to beacon all over the south of Scotland, and he marched boldly to Kelso to help in repelling Bonaparte. He has been a poet from his youth upwards, and only the other day we noticed a copy of capital verses from his pen in a Newcastle publication. Besides providing the inhabitants of St. Boswell's with shoes for half a century, John was exalted at one time to the position of postmaster for the village, but we believe he did not find Her Majesty's service very remunerative, and resigned it. It is, however, in his capacity as an angling-writer and fly- 
dresser, that we take the liberty of making mention of our patriarchal friend here. Eighteen years ago he published (through the Blackwoods) a treatise "on River Angling for Salmon and Trout, more particularly as practised in the Tweed and its Tributaries," full of sound information, as well as containing some original suggestions. Since then, he has written, we believe, several articles upon the natural history of salmon, all evincing much sagacity and careful observation. As a fly-dresser, John has turned out as serviceable insects, whether for salmon-fishing or troutfishing, as any man on Tweedside, and, aided by his son Willie (who, like his father, is himself an eminent angler) he continues to dress most killing Tweed flies. Some very noted flies, indeed, are John's own invention, imitated from natural insects. Besides writing on angling, he gained the second prize for an essay on Sabbath observance several years ago, and in consequence made his appearance on the platform at Exeter Hall and delivered a homely speech in his mothertongue. He has, we are informed, been long engaged in compiling an Autobiobraphy, containing some most interesting sketches of contemporary border-life; but the "sad sentence of an ancient date," that man should make his daily bread by toil, interferes unluckily with his literary labours. A man of original cast of mind, of strong natural sagacity, and of honest manly character, all anglers ought to hope that he will be enabled to complete it and leave behind him the homely print of his border-foot amongst the sands of time.

After making a pleasant bend round Drybnigh and back by Maxton, the Tweed passes Mertoun, the seat 
of Lord Polwarth, who is the proprietor of these fishings, and a very successful salmon-fisher. Mertounwater is succeeded by Rutherford-water, which belongs to Sir Edward Antrobus, and is at present let to Mr. D. W. Brown of Longformacus. "The Rutherford-water," says Mr. Stoddart, "forms the commencement of a series of the best rod-fishings in Great Britain. It consists of a succession of casts or pools of various characters-one still and lake-like, another rugged and shallow, a third combining tranquillity with swiftness, and a fourth depth with considerable turbulence." The water is guarded by John Aitken, who is at once ferryman and keeper, and whose cottage has a "but" with a couple of beds for the accommodation of the lessee. Mr. Stoddart gives a list of the "casts" in this and the other waters of the Tweed-every separate spot where salmon usually lie having a separate and often quaint name, deriver either from rock, stone, or other feature in it, or from some angling event which has occurred at it. These names, however, would only occupy space withont being of any benefit to the reader; for, as we have fully explained, salmon-fishing is not open to the public, and those who have the right have always a local keeper to point out the casts and tell their names.

"The trouting on Rutherford water," continues Mr. Stoddart, " is superior to any in Tweed. I recollect my friend, John Wilson, Esq., eapturing with the minnow a creelfull of fish, out of one or two of the

* Mr. Wilson (now of Billholm in Eskdale) is a son of the late Professor Wilson, and transcends even his father as an angler. 
pools, among which at least a dozen and a half exceeded in weight one and a half pounds each, and as many more were full pounders. I have more than once taken trout there with the parr-tail that weighed well on to three pounds. As an additional proof of its superiority, as well as the esteem it is held in by the anglers of Tweedside, I may mention that the majority of the successful competitors belonging to the Teviotdale Fishing Club have achieved their triumphs within its confines, and that the panniers produced on the occasion of their club meetings, from this portion of the Tweed, have generally excited admiration on account of the size and beauty of the trout contained in them." Owing to the preserving spirit, however, there is now some difficulty in the way of angling in Rutherford-water. Some years ago, when Lord John Scott and others became lessees of the Rutherford salmonfishings, they gave a book to their keeper, and instructed him to allow only those persons to angle for trouts who signed their names in it. Professor Low and Mr. Spottiswoode, the succeeding lessees, continued this practice; but Mr. Brown, who now rents the fishings, has improved upon it, and issues tickets giving leave to angle, - any person who goes without one of these tickets being turned away from the river-side. That there is no mistake about Mr. Brown's assumption of the right to prohibit trout-fishing, is clear from the ticket being left blank, to be filled up (by the person in Kelso who is empowered to do so) as giving permission to fish for "salmon" or for "trout." We believe that the lessee of these fishings has not the remotest shadow of a right to impose any such restric- 
tions. It is a decided point that a title to salmonfishing does not carry exclusive trout-fishing along with it-and there is little foundation in any legal decisions for a claim even on the part of ex adverso landowners to such exclusive privilege. If any party of anglers, therefore, want a day's fishing in Rutherford-water, we should have no hesitation in recommending them to go, maugre John Aitken and his master, "and all that ever with them be."

We do not know, indeed, that there is now an inch of water between Rutherford and Kelso, a distance of about five miles, which is open to the public-or rather, which has not been seized upon, and an exclusive private right, in defiance of the public, asserted by force of gamekeepers. Thirty years ago, there was not an inch of it which was not free, and the preserving practice, which is now very rigid, was carefully and insidiously begun. People, under the shadow of Floors Castle, were induced to take written permissions; gradually it came to be known that anybody who fished in Floors water was expected to ask leave, while it was understood that nobody who asked would be refused; and finally within the last ten or fifteen years, what young men can remember as perfectly open to all, came to be obtainable only by special favour of the Duke of Roxburghe or his Chamberlain. We do not know whether leave is at all liberally issued by his Grace or not, and we can easily understand how a keen angler, through whose possessions the Tweed flows as if it were part of them, should desire to have it exclusively to himself; but we confess that we are radical enough to think that the ducal owner of Floors, 
and of the rich and beautiful domain that surrounds it, ought to have been satisfied with what he had, without attempting to rob the public of almost the only privilege that now belongs to it-that of angling for trout in royal rivers.

The Makerston-water succeeds Rutherford; and here, at the Trows, a famous Tweed fisherman, Rob Kerss, used to hold sway as lessee from Sir T. MI. Brisbane. Here, under Rob's guidance, many of the present Tweed salmon-fishers learned the art. Makerston Trows is the name of a part of the Tweed where the river has wrought a narrow way for itself through the rock, and, as parts of the original stone have proved too hard to be worn away, and remain jutting up in the middle of the bed, the water foams, and boils, and rushes round them with great fury, more like the violent streams born of the Grampians than the equable gladdener of Tweeddale.* The angler who can play and bring to the gafi a new-run twentypounder amongst the Trows may consider himself a master in the craft. In Rob Kerss's time, leave of fishing could be obtained in the Makerston-water for payment to him as "guide, philosopher, and friend," - the fish being paid for at the current price, or left; and there were few days during the season on which he had not somebody in his boat, or working a fly into the eddies of the Trows, under his guidance. He was a favourite with anglers of all classes-with peer and peasant alike; and preserved his self-respect, and asserted

* A similarly contracted and rapid part of the Tweed near Yair is called "Yair Trows." 
his independent and original character, under all circumstances. It is related that the late Earl of Home, probably the best salmon-fisher of his day, was on one occasion angling from Rob's boat on the upper part of the Makerston-water; and, as the day was favourable, he hooked and landed several fish in succession. As each salmon was knocked on the head, his lordship refreshed himself from his flask with much self-gratulation, and returned it to his pocket without offering it to the venerable fisherman. Rob gloomily bore this unwonted treatment for some time, but at last, seeing no prospect of amendment, he deliberately pulled the buat to the shore, put up the oars, padlocked it, and walked off in the direction of his hut. The Earl, amazed, called to him to come back, as his day's sport was not nearly over; but Rob replied-" $\mathrm{Na}$, na; them that drink by themsel' can fish by themsel," and left the peer to digest his mortification as best he might. Rob died-leaving a large family of fishermen behind him-about eight or nine years ago; and Makerstounwater, than which there are few better in the Tweed, is now let to the Duke of Buccleuch and his brother, Iord John Scott. Of course, salmon-fishing in it is accessible only to the friends of the bold Buccleuch. In Rob's time, there was no restriction upon troutfishing ; but, in imitation of the Duke of Roxburghe's practice, gamekeepers are now constantly on the watch to turn off any one who may venture to intrude.

Floors-water is next in succession, and is held entirely in his own hands by the Duke of Roxburghe, who owns the south side of Makerstoun-water also, and thence on that side downwards to Carham, a stretch 
of about ten miles. On the north he possesses about four miles of water, of the most valuable description ; and the three miles of it from Makerstoun to Kelso he retains, as we have said, for the amusement of himseit, his family, and friends. The Duke of Roxburghe is perhaps the most successful salmon-fisher of the 'Iweed at the present day, and, by dropping rocks into proper places in Floors-water, so as to induce fish to lie, he has greatly improved many casts, and created several new ones. The Marquis of Bowmont, his eldest son, is already eminent as an angler. We have stated that the public are now rigidly excluded from angling for trouts in this piece of water. Floors Castle is a magnificent edifice, standing amongst fine woods and surrounded by a deer-park. It overlooks the Tweed, and commands a noble view of Teviotdale, and of the ruins of the old Castle of Roxburghe, the ancient seat of the family of Kerrs, and the key of this part of Scotland. In the times of war between the two countries, it was often in the hands of the English, and the Scots Parliament enacted that when it and Berwick were thus in hostile occupation, the severe laws against killing Tweed salmon in close-time should be suspended.

KeLso is the most beantiful of the border-towns. It has a fine old Abbey, as striking almost, in its massive and simple early Norman style, as that of Melrose is in its rich and elegant Gothic. Some of the streets of Kelso are as mean-looking as those of other towns of the same size, but it has a spacious market-place, and is surrounded on all sides by gentlemen's seats and handsome suburban villas. The district is beautifully wooded, and the Tweed here is joined by the Teviot, 
the largest of its tributaries. The view on all sides is very fine. The green Eildons are just far enough off to be softened into blue; the vale of Teviot lies open to the south; the massive shoulder of Cheviot bars the prospect into Northumberland; eastward the fertile Merse smiles like a garden; and to the north, Hume Castle, standing on a huge rock, intervenes between the black and distant Lammermoors. Kelso has about 6000 inhabitants - and we ought not to omit to notice that amongst them is Mr. T. T. Stoddart, the author of various angling-books (his chef d'cuvre being The Angler's Companion) as well as of a volume of poems which has furnished us with a number of quotations, and of several other works in lighter literature. We can perhaps say nothing that will give a higher idea of the suitableness of Kelso as an angling-station, than that we believe Mr. Stoddart, who is a member of the Scottish Bar, has taken up his residence there almost solely because of the conveniences which it affords for the exercise of his rod. Here, too, resides a noted angler-whose superior, indeed, we have not yet heard of-Mr. David Robertson. Tweed, Teviot, and almost all its tributaries, Eden, and the head of Bowmont, are within easy reach, and offer every variety to the angler. The Teviotdale Angling Club, of which Mr. Stoddart is secretary, has its headquarters here, and on many occasions the prize baskets of its members, at their annual competition, have been most ponderous. Mr. Forrest, whose rods and flies are celebrated throughout the kingdom-and have even done yeoman's service in Norway and Canada-has his shop here. Probably his salmon-flies are not surpassed by 
any in Britain. The Maxwellhengh station, at which the North British Railway terminates, and a branch of the North Eastern to Berwick begins, is on the south side of the Tweed about half a mile from Kelso. The line to Jedburgh branches off at Roxburgh, and gives command of the Teviot, the Kale, and the Jed.

Resuming the course of Tweed, the fact that Sprouston-water, which extends from a little below Kelso to Eden-foot, a stretch of nearly three miles, is rented by a Kerss, is greatly in favour of the angler. On this water, which has a very high character, salmon-angling can at any time be attained on the nsual terms-and heretofore bloody has been the annual slaughter of kelts on Sprouston-dub. But this duba large stretch of smooth water-is also the first favourite resting-place of clean salmon and grilse when running $u p$ in a flood; and, under the able guidance of the tacksman, novices have often found themselves slayers of more than one "monarch of the tide" in the course of an afternoon. Mr. Stoddart says-" It has been conjectured, by those competent to judge, that in this pool alone there are often congregated, at the same time, a thousand salmon and grilses. I have witnessed five or six good fish, not kelts, taken out here, in the course of little more than half an houras fast in fact as they could be hooked and played to bank." For a few years by-past, Sprouston-dub, like all other parts of the Tweed, has not been to the salmonfisher what it once was; but it has always its due share of fish. From Kelso downwards, and in the neighbourhood of Sprouston, the trout-fishing is free and perfectly open; and a good inn at the latter place 
affords accommodation to anglers who do not care to conform to the inflexible rules of the railway timetable; or to perform a three-mile walk after their day's sport is over. James Wright of Sprouston is a delicate dresser of Tweed flies both for salmon and trout.

The Eden, which enters from the north a little below Sprouston, is referred to by Mr. Stoddart as held in good repute by the angler. "I have already alluded," he says, "to the superior quality of its trout, which are red-fleshed, and deep in the shape. There is a fall on this stream at Newton-Don, below which the true breed of Eden is intermixed with other varieties. May and June are the months when the Eden trout are in the highest perfection, and the worm at this period is a deadly bait. The largest trout I ever killed in Eden weighed two pounds, and I have frequently taken, among others, a dozen weighing a pound a-piece. Of late years, the fish have greatly decreased in size, but their quality, when in season, is still good." The Eden is, we believe, a very early river, and may be fished in March with good success.

Birgham-water comes next to Sprouston, and is leased by a Scatt. Grilse fishing in August and September is the principal feature of the angling in this district and for the rest of the Tweed; and in some of the Birgham casts, in a good season, great sport may be had. Carham-water, which succeeds, belongs to Mrs. Compton, of Carham Hall, and part of it is, we believe, not let, but retained by Mr. Richard Hodgson for rod-fishing. Although it is upon the grilses that most reliance is to be placed, we recollect to have seen a 27 -pounder taken there, six or seven years ago, 
on the last day of the season. I here is a station on the branch of the North Eastern at Carham, and capital trouting may be had. At the mouth of Carhamburn, which joins the river at the bend above Carham, the Tweed becomes the boundary between the two kingdoms, in place of the "ideal line" which stretches from this point to the Liddel. The Tweed continues to mark the "march" between England and Scotland until about three miles from its mouth, the final absorption of Berwick-upon-Tweed and its liberties by England having diverted the line of division from being thus continued to the sea. The Wark fishings * and the Lees fishings, belonging respectively to Lord Tankerville and Sir John Majoribanks, intervene between Carham and Coldstream, which latter town affords the most suitable position from which to fish the lower part of the 'Tweed.

Coldstream is a border town of about 2000 inhabitants, with Lees House on the one side, and the Hirsel, the modern seat of the Earls of Home, on the other. The late Earl of Home, as we have mentioned, was a noted salmon-angler, and in the neighbourhood of Coldstream most of his triumphs were effected. He is stated to have killed with his rod here a salmon fifty pounds in weight. Few salmon of this weight have ever been caught in the Tweed, the largest of late years having been a little more than forty pounds; but from the largeness of some of the kelts occasionally taken - which are little more than the skeletons of salmon -it is evident that, amongst the "grey schule" which enter the river to spawn in January, fish of gigantic proportions visit the Tweed. Last year, Lori 
Polwarth killed a kelt of thirty-seven pounds at Mertoun, and one of thirty-eight pounds was captured by net at Horncliffe; both of which fish, before being reduced by spawning and living in fresh water, must certainly have been fully fifty-pounders. For salmon fishing, the Tweed at and below Coldstream is chiefly worth visiting in a dry summer or autumn when there have been few floods to carry the grilse up to the more favourite pools above. If grilse are plentiful in July and August, there is generally one to be had where, just at Coldstream bridge, the Tweed on the south side breaks through the "slap" of the cauld. We have heard of great successes in this neighbourhood; but we are bound to state that of late years these have been restricted. We saw indeed last year, in a newspaper which chronicled the feats of a visitor to the district, that of some fifty fish which he had killed in the Lees-water in spring, only one was a clean salmon.

The Leet creeps into the Tweed past the west end of Coldstream, after a sluggish course of a dozen miles through the most level part of the Merse. This stream is remarkable for the size attained by its trout, the richness of their feeding raising them greatly above the average of any other trouts on the border. Trouts of two and three pounds weight are not uncommon in it, and the ordinary weight is from half-a-pound to a pound. The best part of it, however, flows through the grounds of the Hirsel, and is preserved; but above that, three miles below Swinton, it is worth a visit. It also contains pike and very large eels.

At Coldstream there are excellent inns, and good 
fishing-tackle is supplied by Mr. Belloe. On the south side of the river, a mile from Coldstream and more conveniently situated for the railway station, is Cornhill, where admirable accommodation is afforded by the Collingwood Arms inn. From this point the angler can command the Till, and its tributary the Bowmont and Glen, in addition to the Tweed. The Bowmont is a beautiful water, which takes its rise in Roxburghshire, and, passing through the double-village of Yetholm, the historical home of the border-gypsies, skirts the Cheviots, and joins the Till near Ford, close by the base of the small hill of Flodden, where the Flowers 0 ' the Forest were so fataliy wede away by Surrey and his host of Englishmen. About four miles above its junction with the Till, however, near Copeland Castle, the Bowmont receives the College-burn from the Cheviots, and becomes the Glen. The nearest point of the Bowmont from Cornhill is at Mindrum Mill, about four miles off, and here, as elsewhere, the water abounds with trout, although when we last visited it we got a hint that the Yetholm gypsies too frequently made a raid down it with pout-nets. The trout are very fine, as well as plentiful. The College is probably one of the most populous streams in the kingdom, although its inhabitants are tiny; and the Glen, formed by the union of these two, is a celebrated trout-stream. In the neighbourhood of Copeland Castle it is preserved, but otherwise these waters are free. Not so the Till, the public right to fish in which is constantly interrupted. In its upper parts it is called, we think, the Breamish, and above and below Chillingham it belongs to the Earl of Tankerville, who preserves. We believe that 
for a few miles, between Wooler and Etal, there is no restriction,- - the Marquis of Waterford not being a residenter; but at the latter place, for about three miles, it is again preserved-or at least was so when Lord Frederick Fitzclarence occupied Etal House, which is the property of the Earl of Glasgow. One free day in the week only was allowed on this part of the water; but any one who might take up his residence at Etal, the loveliest village of Millfield Plain, or indeed of Northumberland, would probably have little difficulty in obtaining permission to fish every day. Below Etal, for a mile or two on each side of Heaton Mill, the Till is open, but, for the last four or five miles of its course, it is the property of Sir Francis Blake, of Twizel, and is rigidly preserved. The Till is a slow running river, but stretches of water in which movement is barely discernible alternate with brisk streams, and it is stocked with very large trout. We have seen one of seven pounds weight which had been caught in the Till with worm. It is a very early trouting-river, preceding the Tweed and the other neighbouring streams by fully a month in spring. - Trout, in good condition, may frequently be taken in February, and always in March. There are also a great many pike in it, especially in the neighbourhood of Etal and of Chillingham. Salmon enter it pretty freely, but are captured at "locks" at Ford ; and it is, above all others, the stream for whitling-the liveliest of the salmonidæ. Nothing can be more pleasant than to see one of these fish, a pound and a half in weight, dancing its vagaries at the end of a line among the pools of the Till; and on many days of the season the angler in its waters will have 
the opportunity of seeing such a piscatory exhibition. The eels of Till are almost worth fishing for. We should by all means recommend a foray into this part of Northumberland. The scenery and its memories are most interesting. Millfield plain, the large alluvial basin through which the Till flows, was once the headquarters of the British Druids; and a sacred hill called the Yevering Bell is said to have in those old days overlooked a city more populous than any now in the district. Tradition says King Arthur fought the first of his twelve famous battles at the junction of the Glen and Till. Near the quaint old town of Wooler is the scene of the battle of Homildown Hill, and a little further down that of Flodden; and from any part of the ridge that rises up to the Cheviots, the course of the march of the English army on the last occasion, along the east bank of the Till, to where it crossed at Twizel bridge-which still stands-may easily be seen. No one can help wondering at the folly which permitted such a movement, when it might have been so easily opposed. Nearer Cornhill a rather more apocryphal battle-field-that of Chevy Chace, as distinct from Otterburne, which is in Reed-water, on the other side of the Cheviots-is pointed out.

Learmonth-burn, which enters the Tweed a little way above Cornhill, contains trouts.

Net-fishing is practised at Coldstream, and also at 'Tweedmill, three miles further down. There is good trouting between these points. Below Tweedmill-cauld, a famous run called the Chapel-stream gives the Tweed unusual swiftness just where the Till slowly immerges, and gives point to the bit of doggrel- 


\section{"Tweed says to Till, What gars ye rin sae still? Till says to Tweed, Never ye heed;}

Though ye rin fast and I rin slaw, Where ye droon ae man I droon twa."

We have a notion that it is the almost overwhelming rapidity of the Chapel-stream which induces such a large proportion of whitlings and even of salmon to turn aside and enter the Till in spring. At the foot of the Chapel-stream there is one of the best salmoncasts in the lower part of the Tweed.

The stream we have mentioned takes its name from a chapel, once dedicated to St. Cuthbert, now a mere ruin, beautifully seated in the little haugh formed by the angle of the Tweed and Till at their junction. According to the legend, the stone coffin in which St. Cuthbert's body miraculously floated down the Tweed from Melrose on its way to Lindisfarne, came ashore here, and was preserved for centuries, until some neighbouring Goth began to use it for a pig-trough, and finally broke it. It is said-we do not know on what kind of authority - that such a shell actually existed, and, what is more, was so thin as to float in water. On a precipitous bank overlooking the mingling of 'Tweed and Till, stands a huge abortive structure called Tillmouth Castle. It was built, at enormous expense, thirty or forty years ago, by Sir Francis Blake, but has never been finished or inhabited.

The fishing at Tweedmill belongs to the Earl of Haddington, and between that point and Norham, a distance of about four miles, the proprietors are Sir F. Blake, Mr. Home of Milngraden, and Mr. D. M. 
Robertson of Ladykirk. Save in exceptional seasons, when grilse are plentiful and there are no floods to induce them to run up, there is but little salmon-fishing with the rod in this part of the Tweed. A capital day's trout-fishing may, however, be had in this stretch of water, by the woody banks of Milngraden, the streams and little islands of Bendibus and the Dreeper, and the pleasant braes of Ladykirk-ending at last where "Norham's castled steep" rises gaunt and ruinous over the "fair river, broad and deep," flowing majestically onwards to the sea.

Norham is an ancient border village, quiet as English country villages usually are. The angling visitor at it feels constantly overshadowed by the ancient Castle, and as he wades into the deep stream that wheels round the base of the knoll on which it stands, he of course keeps repeating to himself the fine opening lines of Marmion. High spring-tides reach Norham, but there is still good trout-fishing in the Tweed, and we have many a time filled a creel between it and Berwick. Every two or three hundred yards now, there is a netting-station, and towards the mouth of the river the stranger is amazed at the sight of tall ladders, with a box or cage on the top of them, reared on its banks. Over the edge of the box or cage a face may be detected peering steadfastly into the Tweed at the head of some shallow stream, and as a ripple-invisible to the inexperienced-marks the upward passage of a fish, the watcher pulls a string which drags an old kettle across the floor of the sheil, some fifty or a hundred yards off, where the fishermen are sleeping or mending their nets. Out rush a couple of booted Northumbrians-one jumps 
into the boat, and the other seizes the rope attached to the net-the boat makes its circle in the water, and it is five to one that in ten minutes the salmon is gasping on the bank. Of course there is no rod-fishing where these shots are pulled; but in rocky places, where nets cannot be wrought, where salmon or grilse are induced by drought to lie, instead of making their way up the river, the angling is sometimes excellent. We are acquainted with an angler who, we have been told, killed seventeen salmon and grilse in one autumn morning, in the stream below the Chain Bridge, about four miles above Berwick, a part of the river which the tide covers every day. At Horncliffe there are one or two casts that are always worth trying when the river is not in a state to induce salmon to run.

BERWICK is a town of 13,000 inhabitants-the terminus of the main line of the North British Railway -and with all the accommodation that angler or traveller could desire.* About two miles above the town, the Tweed receives its last ally, the Whitadder.

And so the Tweed is wedded with the sea. The moisture from a thousand hills-the tiny contributions of a thousand rivulets-all the waters that make glad our border-land-represented in one broad stream, pass through the arches of the old bridge of Berwick, double round Spittal Point, dash against Queen Elizabeth's pier, and, gliding swiftly outwards, are lost in the German Ocean.

"For a short description of Berwick, see the " Handbook to Berwick-upon-Tweed." 


\section{$97)$}

\section{CHAPTER IV.}

\section{ETTRICK AND YARROW.}

"Ettricke Foreste is a feir foreste,

In it grows manie a semelie trie;

There 's hart and hynd, and dae and rae,

And of a' wilde bestis grete plentie."

The Sang of the Outlaw Murray.

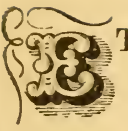
TTRICK FOREST is still fair-but not with seemly trees. Scanty and scrubby are now the representatives, in cleugh and on hill-side, of the ash, the birch, the alder, and the rowan-tree, that by their abundance gave the district its name and its old character-affording shelter in the remotest times, to the bear, the bison, the wolf, and the stag, - to the native Britons, when the Roman conqueror had pitched his camp on the Eildons, and lorded over all he surveyed from that lofty post-in the later or historical and ballad-times to the outlaw and the reiver, and the great families of Douglas and Scott. It is still the "the Forest," however; and, although with the trees have passed away the "hart and hynd, and dae and rae," there remain the lochs, rivers, and rivulets, and their original inhabitants. The salmon hardly now penetrates to the Ettrick and Yarrow, save in breeding-time, but at that period every stream is ploughed up by spawners, and a greater number of them escape the leister than might 
have been expected, for the Duke of Buccleuch vigorously interests himself in their protection. This, however, has only been of late years ; and indeed, instead of wondering that the salmon should have decreased in our rivers, the marvel seems to be that they have not shared the fate of the larger feræ of the dry land. It is to be borne in mind, that notwithstanding the severity of the Scottish laws against killing breeding salmon, they must have been almost entirely inoperative, from the fact that the chief breeding-places were always beyond the reach of the law. The inhabitants of Glen Lyon or Glen Tilt were not likely to pay much respect to the "Lawland laws" that forbade the taking of the salmon in winter to give a relish to their oatmeal bannocks, and afford an alternation of kipper with their tough venison hams. They would doubtless turn up their nostrils in supreme contempt at the idea of refraining from spearing the foul fish in order that the burghers of Dunkeld, Perth, or Dundee, might get them clean. The sparwning-grounds of the Forth and Teith were in the country of the Macgregors, and these sharp-sighted children of the mist would always have an old claymore blacle, or perhaps even a weapon so civilized as a leister, ready for the visitors from the Bass Rock and Inchkeith. As to the Tweed, there were, as we have seen, times-and these frequent ones -when it was declared patriotic to kill every salmon that could be got, so as to disappoint the English loons who held Berwick; and even at this date, the intelligent and moral population of Roxburghshire, Selkirkshire, and Peebleshire-sound, nay learned, as they are on all doctrinal points, and familiar from their childhood 
with the Shorter Catechism and the Whole Duty of Man - are far from recognising the obligations laid down in certain statutes made and provided for the protection of the salmon-fisheries of the river Tweed and its tributaries. Combining the poaching in the upper streams with the netting of kelts in the lower part of the Tweed, probably not ten per cent of the fish that have entered in winter to spawn have hitherto been allowed to return to the sea. Those killed in this way have not, of course, appeared in any statistics of the annual yield of salmon, but nevertheless have exceeded the entire numbers of clean fish taken in the proper season; and, taking this slaughter along with the capture of grilses, which are fish that are killed before they have ever helped to propagate their kind, we have what might appear amply sufficient-reasons for the diminution of salmon. Unless, indeed, they breed in the sea-which there is no good ground for believing -we cannot help being amazed at the extraordinary fecundity which keeps up the species as it is kept up in the face of so many and such comprehensive destructive processes ; for after all, it is not until, as in the case of the Clyde, the filth of a great city and it factories gives the finishing blow, that the salmon is rooted out from our rivers. Even in the Clyde, a few fish still make their way up every year past Glasgow to Stonebyres Linn.

Lnckily, the river-trout is individually nearly as prolific as the salmon, and there is less temptation to pursue it by the methods or to the extent that would involve the risk of destroying the breed. There has always been and still is a certain amount of netting, 
especially in the neighbourhood of manufacturing towns; but we are glad to learn that it is much on the decrease. For the last twelve or fifteen years there has been a penalty provided for such kinds of fishing, by Lord Minto's Act; and although every village has probably still its pout-net or two-one kind of which has a long pole for capturing trouts when driven to the side in heavy floods, the other having two stilts, and being thrust below banks chiefly in burns-they are not very deadly, and are generally used as much for sport as for profit. There are many anglers who could with the rod beat either of these kinds of net; and it is to the more destructive "harry-water-nets," made of such fine cord that they may be earried in the pocket, and which sweep down and almost clear out the whole stream, that the decrease of trouts, wherever they do decrease, is to be attributed. Such places as Hawick and Galashiels are the head-quarters of the poachers who use nets of this kind, and they generally practise their illegal work at night sheerly for the sake of gain. There is a strong indisposition on the part of the people of Scotland to inform against poachers of any kind, and landowners do not place such value upon trouting as to take measures for detecting them, so that the law has never been so well enforced as it ought to be. Perhaps the only plan of stopping this kind of poaching is for anglers to form themselves into societies for the protection of the rivers in the districts where it is practised; and, by employing the more notorious poachers as watchers, on the old principle of detection, it might soon be got under control. To their credit, the Scotch landowners have never availed 
themselves of the power of netting which is so improperly given to them by Lord Minto's Act. There are no such exhibitions on the Scotch borders as are common in some parts of England, of parties of ladies and gentlemen assembling to enjoy the sport of netting a river for tront-such, for instance, as that which occurred on the Eamont in Cumberland some half-dozen years ago, when Lord Brougham and his friends were interrupted by a party of watchers, and had to make fight in order to keep the net from the clutches of their opponents. The execrations of the angling-community would probably stop these attempts, even if they are to be held legal; but we are happy to believe that better notions of sport, and some lingering compunction as to the rights of the public, are in Scotland sufficient to deter the class possessed of the privilege from ever proposing to use it. It is to the English notions of exclusiveness, of carefully keeping to oneself whatever one is entitled to, that we owe the prohibitions of sport, and the shutting up of pathways, that have led to so much ill-blood of late years.

The Ettrick is most readily approached from Selkirk, a little above which town it is joined by the Yarrow. It rises near the foot of Ettrick Pen, a high hill which also overlooks the source of the Esk. The very head of the Ettrick lies nearer to Moffat than to any other point to which the angler can be conveyed by railway or other regular means; but there is not any accommodation to be had above Tushilaw, about ten miles from the source of the river, and about thirteen miles from Selkirk. So that, if he wishes to fish the upper part of the Ettrick, he must take up his 
quarters at Tushilaw Inn, where there is admirable accommodation, provided, in great measure, for the convenience of anglers. There is a good road up the whole vale of Ettrick from Selkirk; and there is also a road from Hawick to Tushilaw, the distance being about fifteen miles.

The Ettrick, for the first few miles of its course, receives but insignificant accessions, the burns that pour in from the hills being short in their courses and small in volume. Its first important tributary is the Timah, which is almost its equal in size, and enters it a mile below Ettrick Kirk. "Moorland Rankleburn" enters about a mile above Tushilaw, and just opposite to the ruins of the old Tower of Tushilaw, a strong fortress of a branch of the Scotts, the last of whom, Adam Scott, commonly called King of the Borders, was hanged on an old tree-which we believe still stands in the court-yard-by James V. in one of his celebrated expeditions against the lawless chiefs of the borders who refused to remainat peace or to recognise his authority. The fishing in all these waters is excellent, the trout in the upper part of the Ettrick, and in Timah and Rankleburn, being very numerous, although of a small average size. We have heard that the Hawick netters make raids to the Ettrick, but can hardly think that they can be frequent ones, or can materially affect the fishing. The waters here, however, are late-indeed we may say that both Ettrick and Yarrow are altogether later than the majority of the border streams. The best fly-fishing is to be had in May; and about the middle of that month, during a flood, great quantities may often be taken. For sum- 
mer worm-fishing, there are few stations more suitable than Tushilaw. Near the head of Rankleburn there are several small lochs-that of Clearburn sending out a small tributary to join Rankleburn, the others being at the head of the Ale-water and its feeders-and there are trout, and we believe perch, in all of them.

Ettrick parish, through the centre of which the Ettrick flows, is thinly inhabited, there being a population of only about 500 people to a district 12 miles in length by 10 in breadth. There can thus be only about 100 adult males-surely a falling off since the days when the lairds of Tushilaw, Thirlestane, and Buccleuch, could each raise his troop of armed retainers to plunder either on the English border or in the vale of Tweed. There is no district richer in border tradition. In the recesses of a small glen which communicates a rivulet to Rankleburn, was the original hold of the Buccleuch family. It was in this cleugh that the buck was seized by the stalwart Galloway fugitive-according to Satchells' story and the name originated that has such a long tradition, and is now so powerful in the south of Scotland. At Tushilaw,-

Where wildered Ettrick wanders by,

Loud murmuring to the careless moon,

Hogg has laid the scene of one of the finest ballads of The Queen's Wake. A little farther up is the old Tower of Thirlestane, the possession of a Scott who was dubbed "ready, aye ready," by his sovereign when other chiefs faltered in offering their spears to support the monarch in his proposal to march into England to wage a foolish and most disastrous war. 
There is a modern Thirlestane Castle now beside the old tower, belonging to Lord Napier, and there are also some fine woods of recent growth in the neighbourhood. Gamescleuch, also a hold of the Scotts, is opposite. But perhaps as interesting as these memorials of mosstrooping times, is a little old cottage, standing at the roadside above Ettrick Kirk, where James Hogg, the Ettrick Shepherd, was born. James Hogg is the tutelary genius of the Forest; and, to our mind, his life and labours are amongst the most remarkable of any that have yet been recorded. Never had genius to surmount greater difficulties before it found expression or recognition. Just barely able to spell through Blind Harry when he was twenty - unable to write with anything like accuracy when he was thirty-still a tarry-handed shepherd when he was forty-he has yet left some songs that are almost unsurpassed in their sweetness, and some poems that are wonderful in their delicacy. Never was genius united with commoner clay; but yet never did genius more truly manifest itself. Never was poet more conceited (in some respects he was even coarse and vulgar); and yet he wrote "Kilmeny," and "Mary Scott," and "The Abbot M'Kinnon," and dozens of poetical pieces exhibiting singular command of language and great variety of beautiful thoughts. Sure nobody ever dreamed so prettily of fairies and elves, since the kingdom of Oberon and Titania was unveiled to the world, or since the nameless old minstrels, his predecessors, left their ballads in the memories of the borderers. Let us be thankful that James Hogg was not born to wealth and an education at a university- 
else had Ettrick and Scotland been deprived of some of the finest lyrics in all the world, and we had not known how all-powerful Nature is in inspiring a simple shepherd with a mental fire that the highest intellectual culture is unable to kindle.

The recollection of the fact that in Ettrick Kirkyard lies the Rev. Thomas Boston, umquhile minister of the parish, and author of "The Fourfold State"a great work of village divinity-induces us to warn our readers to take some readable books with them in their angling excursions to remote districts. Josephus, Boston, and such-like, are often the only books to be found in these places; and the remembrance of a Sunday's torments which we once experienced from the aforesaid "Fourfold State" are not to be effaced. The landlord of an inn, instigated by a thoughtless hint, persisted for a whole forenoon in reading to us the lucubrations of the famous minister of Ettrick; and, as he came to each orthodox proposition, he made sure of our attention by demanding- "And hoo d' ye think he pruves this pint?" Nor would he proceed until a few random guesses gave him the opportunity of exhibiting the superior acumen of his favourite divine on the "kittle points" of faith or grace.

Below Tushilaw, the trout of Ettrick are larger, and all kinds of angling may be successfully practised. About eight miles below Tushilaw there is an inn at Ettrick Bridge, from which the lower part of the river may be conveniently fished. Many old stories and traditions still cling to the locality-as witness the names of Gilmanscleugh, Deloraine, Singlee, the Fair Dodhead, whence Jamie Telfer's kye were stolen, Oak- 
wood, the residence of Michael Scott the wizard, whose industrious imp "cleft the Eildon hills in three, and bridled the Tweed with a curb of stone," and Carterhaugh, the scene of the beautiful romantic ballad of "Young Tamlane." Just below this haugh, which is part of the finely wooded grounds of Bowhill, a favourite residence of the Duke of Buccleuch, the Ettrick meets its twin sister the Yarrow.

Tibbie Shiels' Inn, on St. Mary's Loch, at the head of the Yarrow, is certainly at present the most famous angling-resort in the south of Scotland. It stands on the neck of land that separates St. Mary's from the Loch o' the Lowes, and has, out of all sight, the most beautiful situation of any fishing-inn that the border angler can visit. Surrounded by steep green hills, the two lochs lie so sweetly-whether bright under the summer heavens, while

"Not a feature of those hills

Is in that mirror slighted,"

or more greyly reflecting a cloudy sky, and rippling with a southerly wind-that the weary wandering angler, as he descends upon them, feels as if he had at last reached the Fisher's Elysium. 'Tibbie's, with its little circle of trees and its cosy parlour, is in complete harmony with the picture-comfort modestly and fittingly putting in its claim to a corner even in realms of fairy beauty. Nor did angler, since the days when Father Izaak rested and sang his simple songs in the honest alehouses on the banks of the Lea, ever meet with more kindly care than he will receive in Tibbie's homely hostelry. Tibbie, or Mrs. Richardson, for to that name she is entitled,-only anglers have got the 
more familiar one into their mouths-is now 75 years of age, but she is still active and attentive, and most motherly in her ways to her visitors. Under her roof all the best fishers and many of the finest wits of Scotland have at times disported themselves, and in the mouths of the collocutors of the Noctes Ambrosiance her name was a frequent one. And, if you ask her, Tibbie will tell you stories of James Hogg and Professor Wilson, and others of her favourites. "For I ser't wi' Mr. Hogg, ye ken, fifty years syne, owre-by at Ettrick House; and whan he leeved at Altreeve he was often often up here, sittin on that very sait there, carryin' on his fun wi' the Professor. An' oh but the Professor and a' the family has been kind till us, and brocht us intil muckle public notice, an' puttin' us forrit in a way that we couldna weel hae expeckit."* Long may she live to welcome her guests from all the points of the compass!-for she is a part of the scene, and the removal of Tibbie would be almost like the drying up of the Loch o' the Lowes.

* The scene of one of the Noctes is laid at Tibbie's, and the Shepherd, North, and Tickler, in turn compare her cottage to a wren's nest, an ant-hill, and a beehive :-

"Shepherd. A wren's nest's round and theekit wi' mosssae is Tibbie's; a wren's nest has a wee bit eanny hole in the side $o$ 't for the birdies to hap in and out o', aiblins wi' a bit hangin' leaf to hide and fend by way o' door-and sae has Tibbie's; a wren's nest 's aye dry on the inside, though drappin' on the out wi' dew or rain-and sae is Tibbie's; a wren's nest's for ordinar biggit in a retired spat, yet within hearin' o' the hum o' men, as weel 's o' water, be it linn or lake-and sae is Tibbie's; a wren's nest's no easy fun', yet when you happen to keek on't, you wunner hoo you never saw the happy housie afore-and sae is 't wi' Tibbie's; therefore, sirs, for sic reasons, 
The two lochs are together about four miles in length, that of the Lowes being nearly a mile, and St. Mary's being rather more than three miles. They wind amongst the hills, expanding or contracting as the latter recede or jut out, but nowhere is St. Mary's more than half a mile, while the Loch o' the Lowes is only about three or four hundred yards, in breadth. Salmon and bull-trout make their way up the Yarrow so far in close-time, and have even been caught in St. Mary's at other seasons. St. Mary's is the best for the trout-fisher, being full of fine fish, which, although capricious as the trout of all lochs are, often well repay the angler's labour. They do not attain the size of those of most of the Highland lochs, and a trout of more than a pound and a half in weight is not at all of frequent occurrence; but the greater proportion of them run from six ounces to a pound, and are thus of course superior to the average of most of the border streams. These lochs can be fished sufficiently well from the side, or by wading, there being no tempting islands or shoals in the middle which it is desirable to reach; and the angler can of course accommodate himself to the wind, when there is any, by fishing from the bank on which it favours his cast.

Loch-fishing can seldom be practised with much success, without a smart breeze. Occasionally towards

and a thousand mair, I observed, ' a cosy bield this o' Tibbie's, -just like a bit wren's nest.' "

And so each goes on amplifying his illustration. Tibbie's, however, is no longer " theekit wi' moss," but has got a slated roof, and an ele that had come to be much wanted. She has now, in one corner and another, seren beds for the accommodation of her visitors. 
sunset on a calm evening, trout will begin to rise to the fly with surprising readiness, and a lucky hour of that kind is often worth a whole day's work. But as a rule, when a lake lies a calm blue sheet, reflecting every hill and shadow, it is better to take to the streams which feed it, however insignificant they may be. Fortunately the visitor to St. Mary's has no difficulty, and when Alus refuses to do his duty, he need not cast a single longing lingering look behind, as he turns to the Meggat, Little Yarrow, or any of the neighbouring burns. In St. Mary's he must use larger flies than in river-fishing, although it is unnecessary to use them of the sizes sold by the tackle-makers for the northern lochs. His largest size should indeed be a size smaller than the smallest Highland flies, nor should they be of the gaudy hues that take the fancy of the inhabitants of Loch Rannoch or Loch Lubnaig. The drake-wing is a good fly in all its combinations, and it is advisable to experiment with a green or a yellow body; but-except perhaps when the waters are coloured-there is no necessity for tinsel, and the common winged flies, dressed a size larger, will be found in general the most killing. When the day is dark and the breeze strong, the larger and brighter flies ought to be employed. On such days, should the fish rise reluctantly to the fly, the angler should take at once to the minnow, and by it he will probably capture the largest trout; while on a bright day, with a gale, the worm may sometimes be employed with success. The worm should be thrown out with a long cast, allowed to sink a little, and then drawn in with slow jerks. We hesitate to recommend the otter as a proper instrument of the angler; but 
should any one be clear in his conscience about the use of it even on a loch, he will often on a breezy day find it effective on St. Mary's.* It is not till the middle of April in the earliest season, and the beginning of May in a backward one, that there is much chance of success in trout-fishing here.

The minnow-fisher, who is willing to risk his tackle, may in the lower parts of the Loch o' the Lowes, and about the head of St. Mary's, take his chance of hooking pike or large perch, as well as trout, when practising his art with a large minnow on a windy day. But as pike are apt to bite through gut-though we have had good jack-fishing with common troutingtackle-it is better to angle for them by the ordinary methods, which we have not yet described. The most common pike-tackle consists of the double hook attached to a piece of twisted brass-wire, which by means of a needle is drawn up through the bait-not through its entrails, but inside the skin-leaving a hook projecting on each side of the mouth. The bait usually employed is a parr or small trout, ranging in size from half an ounce to two or three ounces, according to the size of the fish that frequent the casts. The bait is thrown out as far as is thought desirable-usually just beyond a bed of weeds; is allowed to sink nearly to

* The otter, we may inform those unacquainted with it, consists of a piece of wood shaped somewhat like the hull of a ship, with a leaden keel, to which a line with several dozens of flies may be attached; and when the fisher-who may either use a rod or not-puts a strain upon it, it strikes diagonally outwards, and may be drawn upwards at any required distance against the current. On lochs it is most easily wrought against the wind. This in the north of England, is called "jacking." 
the bottom, and is then slowly drawn up, and again permitted to sink, and thus bronght inwards until the cast is completerl. Or a running-tackle may be made, consisting of large hooks tied upon gimp, in the same manner as the ordinary minnow-tackle, with one or two large swivels for the purpose of spinning a small trout, parr, or parr-tail, or even the head and half of the body of any of these. There are other and very complicated tackles used for capturing pike, but those we have described are at once the simplest and the best. The most important directions to be given for pike-fishing are, to bring the bait carefully to the side of the beds of weeds, or even amongst them if it can be done with safety, and to refrain from striking the fish when he seizes the bait, until he has pouched it. To this end, a yard or two of line should be kept free in the hand of the angler, and given out without any check when the pike has taken the bait, until he has retreated to his hold and begun to swallow his prey. He will often sail slowly about or remain stationary with it in his mouth for several minutes without trying to bolt it; but, especially when fishing with the firstmentioned tackle, it is necessary to humour him. When, after moving about, he stops for a little, and the angler begins to perceive a strain upon the line, the time has come for striking him; and frequently exciting runs are to be had, although, upon the whole, the pike is not so lively or powerful in comparison with his size as any of the salmonidr, while the tackle is so strong that a great amount of force can be used in exhausting him. When using the spinning-tackle, if a third hook is employed about the middle of the bait, the impa- 
tient angler may perhaps trust to a barb being in the pike's mouth, and strike more rapidly-although, in doing so, we have found the pike hold on for a little, as if surprised at our tugging, and then let go his hold, and retreat unscathed. Should the angler be tempted to try a pike-cast with a large minnow or parr-tail and gut-tackle, he ought to strike at once, or the chances are that if the pike swallow the bait he will sever the gut with his teeth. Many people content themselves with fishing for pike by means of set-lines-the brassarmed double hook being baited in the ordinary way, and thrown into a likely place, a cork attached to the line suspending the bait at any depth. Eels, however, when they are numerous, are apt to interfere sadly with such baits-and everybody is not so lucky as to fall in with 20-lb. specimens of the anguillidæ, as Mr. Stoddart relates he did in such a case in the Teviot. To be such remarkably wary and sagacious animals, river-trout sometimes do singularly stupid things-for . we once canght one, a pound and a half in weight, in the Clyde in clear water, at a pike-line, the bait being a two-ounce trout, with a great hook projecting on each side of its mouth, and six inches of twisted brasswire connecting its tail with a strong cord! Pike are sometimes caught by setting a bait adrift suspended from a bundle of rushes, a corked soda-water bottle, or other " trimmer;" and we have known the jocund rustics of the Till amuse themselves by fastening a small trout to a dnck's leg and making it swim through a deadly haunt of the fresh-water shark, a furious struggle ensuing, if a pike took hold, as to whether the fowl was to be drawn under water or the 
fish drawn out of it. We believe there have been instances of the duck being drowned, although finally the pike also was exhausted and taken. We cannot speak from personal experience of fly-fishing for pike, but believe that it may be practised successfully in windy weather. The fly is a bulky affair, nearly as large as a wren, the principal feature in its composition being two of the transformed eyes of the unfortunate Argus which adorn the peacock's tail. The pike, indeed, will seize anything-is fond of ducklings, although we never heard of anybody fishing with them -and, when other fare is not to be had, will, like a hungry fisher (as indeed he is), sup off a bit of Tibbie Shiels' bacon or mutton-ham if offered to him. A frog is a capital bait, and it is while instructing his pupil as to the way to put a live frog upon the hook, so that it may live longest, that Izaak Walton recommends Venator to " use him as though he loved him!" We shall not, on the present occasion, enter upon any exposition or defence of live-bait fishing, but shall merely remark that many moral philosophers have been particularly addicted to it-and what finer moralist than old Izaak himself ever lived? Yet we would rather that he had not used that phrase.

The pike in these lochs are large, and we believe of good quality. At one time, they were chiefly confined to St Mary's; they afterwards removed almost entirely to the Loch o' the Lowes; and they are now again returning to their former haunts, being pretty numerous in the bays where there are reeds or rushes in the neighbourhood of Tibbie's cottage. The number of pike in the upper loch has always kept down 
the number of trout, although they are said to be getting more plentiful.

Perch-fishing is ordinarily managed by means of a worm and float, and great quantities of the smaller members of that fraternity may be thus killed when the angler gets amongst a shoal. Large perch may be taken by the minnow, and when one of a pound weight is hooked, he has a power of digging down into the depths that is rather gratifying to the angler who likes to see his tackle tested. The round shoulders of a large perch give him considerable strength, and he makes very different play from that most contemptible of all fish, the chub or skelly, which, we believe, is, amongst Scotch rivers, confined to the Esk and the Liddell.

Upon the very verge of Moffatdale, from the one side of the little hill that on the other sends a scanty rivulet down the wild chasm called Dobb's Linn, Little Yarrow takes its rise, and, after a course of four or five miles, enters the Loch o' the Lowes as its principal feeder. It is a shallow stream, and the trout in it, though numerous, are small in size, with the exception of occasional emigrants which run up from the loch in floods. If the trout were more numerous in the upper loch, there would doubtless be goor fishing in Littlo Yarrow after spates. Near the loch it is joined by the Chapelhope-burn, which also is full of small trout. It is here that the scene of Hogg's fine tale, The Brownie of Bodsbeck, is chiefly laid-Bodsbeck being in Moffatdale, and, as well as the Grey Mare's Tail and Dobb's Linn, a great haunt of the persecuted covenanters. Corsecleuch-burn enters at the foot of the loch from 
tho south, and is also well supplied with finny tenants of moderate size.

'The principal contributor to St. Mary's Loch is the Megrat-which, indeed, although it enters the lower loch, is entitled to be considered the true source of the Yarrow, as its course is the longest, and its volume the greatest, of any of the streams issuing from "the bills whence classic Yarrow flows." It rises in Peeblesshire, near the source of the Talla, and, aided by Winterhope and other burns, enters St. Mary's from the north near Henderland. It is one of the most celebrated of trouting-streams in the south of Scotland, has been a favourite haunt of eminent fishers, and probably as great feats have been performed in it as in any other water. It has been recorded- - we are unable to say with what correctness-that a late famous Peeblean angler captured nearly $100 \mathrm{lbs}$. in it with the worm in one day; and many anglers have often, long before the day was done, found their baskets all too small for the captives of their rod and of their line in the Meggat.* In a summer flood, there is perhaps no limit to the numbers that may be taken with the worm in the up-

* Amongst the amusing exaggerations of the Noctes A mbrosiance, the Shepherd is on one occasion made to say- "Anither day, in the Meggat, I caucht a cart-fu'. As it gaed down the road, the kintra-folk thocht it was a cart-fu' o' herrins-for they were a' preceesely o' ae size to an unce-and though we left twa dizzen at this house-and four dizzen at that house-and a gross at Henderland-on countin' them at hame in the kitchen, Ideczy made them out fortydizzen, and Girzy forty-twa-aught; sae a dispute ha'in arisen, and o' coorse a bet, we took the census owre again, and may these be last words I shall ever speak, gin they did na tura out to be Forty-Five !" 
per parts of the stream and the burns that enter it, except that of the angler's ability to pull out the fish, bait, and drop in again ; and further down, better trout may be taken with nearly equal rapidity with either fly or worm. Not that to every angler, or on all occasions, the Meggat will yield such "store of trout;" for many a one has gone out only to be disappointed, and break his shins fruitlessly amongst the rocks at the linns, or sink to the knees in Winterhope moss. But a proficient angler may always make certain of a full basket in the Meggat, from the first of May to the end of the season; and will not grudge the labour of climbing the hills or venturing through the morasses to get to the lonely and mossy moors at the head of Meggatdale. If he intends to take advantage of a flood when the waters are thick, he ought to make at once, in the early morning, for Winterhope-burn, and fish down; if he intends to practise the ordinary worm-fishing in clear-water, he should begin at Henderland and fish up to the linns, below which lie large trout, and then, missing a mile or two, pursue the lonely stream as far as time or fatigue will permit him. Fine trout from the loch enter the Meggat during floods, and basketsfull may be taken with minnow, worm, and fly, one being used after the other as the water gradually clarifies. In all the burns that join the Meggat, trout are in remarkable abundance.

Loch Skene is more easily reached from Tibbie's than from any other point. It is near the head of Winterhope-burn, but, particularly after rain, the mosses in that direction are unsafe, or at least troublesome, to those unacquainted with them. The angler, however, 
may follow the road up to the source of the Little Yarrow, above Birkhill, and thence striking across the hills in a westerly direction, he will easily come upon it. It contains very fine trout-although their taking is not always to be relied upon.

There are a number of roads to Yarrow and St. Mary's Loch, most of which have been already incidentally referred to. The angler may most readily reach the river itself by Selkirk, which is the terminus of a line of railway that branches from the Edinburgh and Hawick at Galashiels. Selkirk is sixteen miles from St. Mary's Loch, there being a good road up the vale of Yarrow the whole way; and a few hours' pleasant walking, with intervals of a little angling, will bring the angler who has left Edinburgh by the morning train to Tibbie Shiels' with time left for a cast in the loch before the gloaming. Anglers, now-a-days, however, usually prefer driving, and there are of course all kinds of conveyances to be had at Selkirk. We have already noticed the road from Peebles, up the Manor and down the Meggat, solely for pedestrians and equestrians, and from Innerleithen, up the Quair and down Mount-Benger-burn. From Hawick, the road by Tushilaw is continued up Tushilaw-burn and down by Altrieve to meet the road from Innerleithen at the bridge below Mount-Benger, while a bridle-road leaves the vale of Ettrick a mile or two further up, and descends on the other side of the hills directly upon the head of St. Mary's Loch. From the west, a good road from Moffat, which is two miles from the Beattock station of the Caledonian Railway, runs up the vale of Moffat and down Little Yarrow to Tibbie's-a distance of fifteen 
miles. This road is continued down the north side of the loch and down the Yarrow.

So now we must bid Tibbie Shiels farewell; and who-as he drank the stirrup-cup at her door-ever did so without regret? Esto perpetua, we would fain say to the aged hostess; but since that may not be, we can only hope that the nest-like shelter between the lochs may for generations be open to the angler, and may be presided over by some one that, in kindliness, attention, and lastly, moderation of charge, may emulate thee, O Tibbie!

As we saunter along the road, by the side of the loch, on our way down the vale of Yarrow, we must pause to note some of the more remarkable features of a scene that has had such a singular attraction alike for the old ballad-monger and the modern poet. There is no swan on still St. Mary's lake, "floating double, swan and shadow," - for only in the hardest winters have these waters such a visitant. But as we pass the mouth of the Meggat, we mark Henderland, near which are the ruins of the old castle which was the scene of one of King James's sudden descents. The royal asserter of law on the borders pounced upon Percy Cockburn of Henderland one morning in 1529, hanged him over his own gate, and left his body with his weeping wife, whose faithful care of his remains bas come down to us in a ballad than which there is nothing more pathetic extant. Having been deserted by every living creature, she herself sewed his shroud, and waked his corpse, and then bore it to St. Mary's Kirk :- 
"I took his body on my back, And whiles I gaed, and whiles I sat;

I digged a grave and laid him in, And happed him with the sod so green.

But think na ye my heart was sair, When I laid the mouls on his yellow hair? And think na ye my heart was wae, When I turned about awa' to gae?"

The ruins of the chapel of St. Mary, which was dedicated to our Lady of the Lorres (lochs), stand on a small table-land, elevated a little above the loch, and not discernible from the road immediately below them. Coming from the head of the loch, however, the traveller may see several pillars surrounded by a dyke, rising up from the rough moor, to the east of a staring little Free-kirk Chapel, with a singularly priggishlooking steeple, which has been reared of late, doubtless out of the "Building Fund" which we hear so much about. The pillars in St. Mary's Kirk are in memory of Mr. John Grieve, and his kith and kin ; and as Mr. Grieve, besides being a respectable hatter in Edinburgh, was a warm and effectual friend of James Hogg, in his worst as in his best days, his memory may be forgiven for being preserved upon pillars that most people would wish anywhere but where they are. The little kirkyard is still a much-frequented burialplace in Yarrow and Ettrick, and numerous gravestones tell the brief story of the birth and deaths of the Forest. The Lord William and Lady Margaret of "The Douglas Tragedy" were buried here, according to the ballad, - the result of their interment being a floral phenomenon that has since been greatly affected by parish minstrels in all par'is of the lingdum:- 
" Lord William was buried in St. Mary's Kirk,

Lady Margaret in Marie's quire;

Out o' the lady's grave grew a bonny red rose, And out o' the kuight's a brier"-

the love which they had borne to each other being represented in the twisting and twining of the rose and the brier, until "bye and rade the Black Douglas" the lady's father, who "pulled up the bonnie brier, and flanged in St. Mary's loch." The scene of the Douglas Tradegy itself - the elopement of Lady Nargaret with Lord William, and of the unequal combat in which her brothers fell before her lover's sword-was in Douglas-burn, which flows into the Yarrow about three miles farther down. In St. Mary's Chapel also, was the more satisfactory denonement of "the Gray GossHawk," when the lady, after having been carried in her coffin for dead out of England to be buried here, was awakened by the kisses of her lover-a pleasant catastrophe imitated in Hogg's "Mary Scott" which we have already mentioned. The real Mary Scott, the Flower of Yarrow, was born at Dryhope Tower, and was married to Sir Walter Scott of Harden in Roxburghshire,- the prudent father agreeing to keep his son-in-law and daughter and suites for a certain time at Dryhope, but requiring the security of a number of barons for his newly-acquired mosstrooping relative, that at the end of the agreed period he would remove without any attempt to establish himself by force. Dryhope Tower is in full view, about a mile from St. Mary's Kirk, and is a fine specimen of the ancient square border "peel." From the Chapel, indeed, perhaps the finest view of the loch and its scenery may be obtained,-Tibbie's strip of planting running 
into the water at the head, Bourhope lying snugly in a wooded cleugh on the opposite side, and the blue Yarrow itself at the foot, winding through the bare valley. The Free Kirk we have noticed, and a farmhouse newly erected at the foot of the loch, are the only modern-looking intruders upon a scene where we fear our readers will think we have already lingered too long.

Kirkstead-burn, which enters just at the foot of the loch, is full of small trout, and we fancy but little fished. Mr. Stewart informs us that upon one occasion he canght twenty-three dozen in it.

The Yarrow is rather a late water, and fly-fishing in it is somewhat uncertain. The trout, however, are of good size, and it is well adapted for angling with minnow. Many very heavy baskets have been got out of it in the first mile or two from where it flows out of the loch. About two miles downwards it is it is joined by Donglas-burn, which has a high reputation as full of small trout, and in a flood almost any numbers may be taken out of it. The Gordon Arms Inn is situated about a mile below the junction of Douglas-burn, or about seven miles from Tibbie Shiels's and eleven from Selkirk, and is in great measure intended for the accommodation of anglers. It is indeed most suitably placed for fishing the middle district of the Yarrow. From the other side enters Altrive-burn, in the little valley of which is situated Altrive farmhouse, where James Hogg long sat rent-free under the Duke of Buccleuch-although, even under that arrangement, with poetical perversity he found himself hardly able to make both ends meet. The farm of 
Mount-Benger, which he held as a "led-farm," is a few miles farther down.

Space does not allow us minutely to trace the vale "Where Yarrow rows among the rocks, And wheels and boils in many a linn ;"

or to dwell further upon the traditions of its "dowie dens." There is no interruption to the freedom of angling until the river bends southward at Yarrowford, about five miles above Selkirk, when it is taken under the protection of the Duke of Buccleuch. It here loses its pastoral character in the "pomp of cultivated mature," the woods of Newark and Bowhill rising beantifully on its banks. Newark Castle, now in ruins, was an ancient residence of the Buccleuch fanily, and is the place where Scott makes the last minstrel sing his lay to the widowed Duchess of Monmonth and Buccleuch. The Duke is, we believe, something of an angler, and has done a great deal to protect the salmon breeding in this district. Under his Grace's direction, we presume, his head gamekeeper, Mr. James lierss, some years ago instituted some interesting experiments as to the growth of salmon smolt in fresh water." It appeared that, after being

- It occurs to us, that in describing the Tweed we neglected to notice some experiments in the breeding of salmon that have been made in a burn near Floors Castle and in another at Paxton, near the mouth of the Tweed. Under the direction of the Superintendent of Tweed police, ponds were constructed in imitation of those at Stormonthfield on the Tay, in which impregnated ova were deposited to be hatched. We remember having taken a specimen of the young salmon, two months old and about the size of a small minnow, from the lower pond; but we do not know what the result of the experiments was. Probably they failed through bunging or inattention. At in- 
kept for a year or two in a pond at Bowhill, from which wire-grating prevented any egress, they were found to have increased greatly in length, without anything like a proportionate increase in thickness, but had bright scales, and exhibited a great deal of restlessness in their confinement. Similar experiments have been made with similar results in other parts of the country. We do not know whether the fish still remain in the pond.

tervals for the last fifteen years, howerer, experiments as to the history and habits of the salmon lave been conducted at the mouth of the Tweed. Smolts have been marked on several occasions, by cutting their fins, or by twisting loops of thin silver wire into their gills or tails. Narking by the mutilation of fins is however a most unsatisfaetory method of making such experiments; and nothing certain ean be affirmed from it. But of the smolts marked with silver wire, three, we believe, have been reeaptured as grilse. The results are contrary to the common belief of the grilse's age. We have seen two. one of which was marked with wire in the tail as a smolt in May 1851 and taken again as a 4-lb grilse in August 1852; the other was marked with wire in the gill, as a smolt in May 1855, and caught again as a grilse in 1856. The former of these fish is at Berwick, the other is in the possession of the Duke of Roxburghe at Floors Castle. Nany kelts have also heen marked to ascertain the difference between their condition when kelted and when clean; but, so far as we have heard, with nothiug at all like the surprisingly exact returns that Nr. Andrew Young of Invershin chronicles. Of a number of kelts of the salmo eriox marked at the mouth of the Whitadder, one was shortly afterwards caught at the mouth of the 'Tyne, another at Yarmouth, and the skeleton of a third, with its gutta-percha tieket, was found in the stomach of a cod captured at Lyemouth! But although the marking has been repeated amually, we do not know that in a single instance a ticketed kelt has been recaught as a clean fish., 
The old town of Selkirk, whose famous "sutors" bearded the Earl of Home, has in itself no particular claims as an angling station, although the Ettrick immediately above it is, we believe, free, and contains good trout. Below the town the river is damaged for angling-purposes by the factories; but towards its junction with the Tweed there are some good casts, especially for roe in winter. A little above Selkirk, on the north bank of the river, is the plain of Philiphaugh, where Montrose was so thoroughly routed one misty morning in 1643 by Sir David Leslie and his Covenanters. Below Selkirk, on the south, is the Shaw-burn, specified in the ballad, where Sir David addressed a piece of advice to his army, about which there is some little dispute :-

"When they came to the Shaw burn,

Said he, "Sae weel we frame,

I think it is convenient,

That we should sing a psalm."

A various reading makes the stout general rather suggest that it was convenient " that we should tak $a$ dram ;" and considering that it was a raw misty morning, and that the grand object was to come upon Montrose by surprise, we should think commentators ought to have no difficulty in making up their minds which version is the correct one.

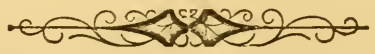




\section{CHAPTER V.}

THE GALA AND THE LEADER.

$\mathrm{F}$ all the waters in which the anglers of Edinburgh exercise their art, the Gala is that witb which they are most familiar. It can be reached in an hour by railway, and trains three or four times a-day afford the opportunity to visit its banks. Accordingly, on almost every day of the fishing season the citizens of Edinburgh seek their sport in the vale of Gala, and on fast-days or other holidays the numbers of persons, rod in hand and creel on back, that may be seen pouring down Waverley Bridge from all quarters are something portentous. W. S.'s from the New Town drive desperately up in cabs; from the Old Town, down these wonderful "closes" rush dozens of every grade and station; steady old hands from Leith, most of them in the spirit trade, make their appearance; there are a couple of Sheriffs, a sprinkling of editors and sub-editors of newspapers, probably a Professor, undistinguishable from an ordinary mortal; - lots of medical students, the most easily recognisable class of the genus homo-and there is every likelihood that, regarding his fellow-craftsmen with curious eye, and inwardly chuckling over the idea that by the evening his ample basket will contain a weight about equal to all the others put together, may be descried the six-feet-two form of Mr. W. C. Stewart, the best 
angler in Edinburgh. When the train reaches the head of Gala-water, at every station a cloud of witnesses to the love of angling prevailing in the metropolis drop off; and although a few of the angling passengers pass Bowland, intent upon the "Nest," the pools of Rutherford, or the streams of Mertoun, the green valley for the day becomes populous, and the trout that dwell therein are amazed by the rapid succession of leashes of new and strange-looking entoma that float past them. There is no stream that has such railway facilities as the Gala. On about fifteen miles of its course there are no fewer than five stations, every one on its very banks.

Luckily the Gala is most abundantly stocked with the river-trout; and notwithstanding the numbers of those who cast angles in it, there is no prospect of a serious falling off. It must be confessed that a great proportion of the metropolitan anglers who resort to it do not seriously reduce its population, and a census taken the day after the Edinburgh fast-day would probably find only a few hundred fish amissing as compared with the day previous to that solemn occasion. Mr. Stewart states that the Gala is fished by about thirty anglers daily during the season, and "supposing" they average only two pounds a-piece," he thereby makes out the capture of an immense number of trout. If we take the fish as averaging five to the poundwhich approximates to the size of the trouts taken by fly in small streams-we have thus a destruction of 300 per diem; and supposing it to continue over a hundred days in the year, the "total casualties" would reach the figure of 30,000 ! Probably as many more 
are taken by net by poachers from Galashiels; but still a good angler on almost any part of it may get a basketful. The Gala, however, requires fine fishingfor all but the first year's trouts have been edueated in gut and feathers, and perhaps about 80 per cent. of the whole number have been pricked by the hook on some occasion, while not a few have been nearly dragged out of the water, or have even slid through the benumbed hands of the piscator who was fumblingly fingering them as he was about to convey them to his pannier. Fear of man has become hereditary in animals since the days when they gambolled before Adam in Eden; and perhaps fish will by-and-by acquire an instinctive knowledge of the lures he uses, and thus avoid the dangerous mouth-test to which they are at present so often subjected.

The proper source of the Gala is Heriot-water. The other stream called Little Gala, which by its union with the Heriot forms the Gala, is much shorter in its course and smaller in its volume. Heriot-water rises in the hilly parish of Heriot, and runs a little more than five miles before it changes its name. In its upper parts, however, it is superior to the ordinary run of hill waters, and the numerous burns that contribute to its size are also better than those of heathery or mossy regions-the hills of this part of Edinburghshire being low and undulating, and covered with green verdure. Heriot-water for the first two or three miles has many deey pools, and its trout have a darker huo and a yellower gleam than the starry-sided inhabitants of the Frala. They are also of good size, and of superior flavour. Perbaps as good sport may be had here 
as in any part of the Gala, for it is not nearly so much fished as most portions, being a little out of the way. With the Little Gala at their feet at Heriot station, and the Gala itself to be reached by following it down, anglers are usually too eager to begin, to think of walking three or four miles to the best part of Heriotwater. It is, however, heavily fished for a mile or two above its junction with the Gala, where its character is precisely similar to that of the main river, being full of small trout that are easily taken after a flood, and that require considerable skill to entice them when the water is clear. Perhaps the best arrangement for a day's fishing here is for the angler to miss the first two miles of the Heriot (by following the road from the station, he comes upon it at Heriot Kirk, more than a mile from the junction with the Little Gala), and then to fish up to nearly its source with fly, worm, or creeper, and back again with minnow. Little Gala presents little temptation to the angler. There is a good inn at Hangingshaw, near the Heriot station.

Unless fishing duwnward with minnow, the angler who wants to fish the upper part of the Gala should go to Fountainhall station and fish up to Heriot. This is an admirable piece of water, there being about three miles of the Gala between these points, and Heriotwater may be followed as far as time permits. While it consists chiefly of streams, there are also whirling pools where large tront harbour, and where fishing may be practised pretty successfully early in spring. The Armet enters the Gala above Fountainhall, a stream not much worth fishing, save in a flood. There is an inn also, we believe, at Fountainhall. 
The next stretch of water, between Fountainhall and Stow, is more rapid, having indeed a constant trot about it that adapts it beautifully for worm-fishing, but rather unfits it for the early fly-fishing. Trout flock into it in the summer months, and in June and July it is well worth a visit. Huge basketsful have been taken from it, however, with fly, as well as May-fly and creeper, for the latter of which it is capitally suited. Creepers and May-fly are usually plentiful throughout the whole course of the Gala and its tributaries, althongh in some years they are more abundant than in others. Stow is a considerable village, with an inn, and is resorted to sometimes by anglers who want lodgings in summer-time within easy distance of Edinburgh. Cockum-water enters the Gala above Stow.

Between Stow and Bowland Bridge (the station below Stow) the water runs more into pools, and contains larger trout than any other part of the Gala. "We once took with the minnow, between Bowland and Stow," says Mr. Stewart, "twenty trout, the whole we got that day, which weighed fifteen pounds, and we never got such a large arerage size of trout in any of the tributaries of the Tweed, or even in Tweed itself." A basketful of twenty trout, averaging threequarters of a pound, is certainly remarkable for the Gala, but it has been frequently surpassed in the Tweed, in the Till, the Leet, and the Blackadder. Mr. Stoddart mentions having caught in the Leet twenty-six trout weighing upwards of twenty-nine pounds; and we have seen an average of a pound attained in the Whitadder with the "lying minnow" - that is, a minnow thrown into an eddy, the line 
well loaded, in a flood, while the water was yet too thick for spinning it successfully. But the truth is, the trout of Gala are small-below the average, indeed, of any other tributary of the Tweed of equal volume. Like those of the human race whom the gods love, perhaps they die young, and only a few are allowed to reach their full stature and ponderosity. This is, however, rather opposed to the ordinary rule, which is, that where trout are very numerous they remain small, whereas when they are thinned by fishing, they increase in size. On the last occasion on which we fished the Gala-(with fly in the end of April, in a bitter east-wind from Fountainhall up to Heriot Kirk) - the six dozen trout which we got certainly would not weigh more than nine pounds, if so much, and there was not a half-pounder amongst them.

The Luggate enters the Gala a mile and a half below Stow. It is its principal tributary, and swarms with trout. Very large numbers have been attained by anglers in this little stream, and with the May-fly a diligent fisher may also pick out an "assortment" of a very respectable size.

Below Bowland, the Gala may be fished for a mile or two, but it here comes into dangerous proximity to Galashiels and its poachers. At that town it becomes a mill-lead, and is mixed with chemicals that poison the fish; and although, between the mills and the Tweed, a few of tough constitution are believed to survive, and were, we understand, counted in order to furnish an answer to the promoters of the new Tweed Act, who wished to strengthen the clause preventing the throwing of deleterious matters into our border streams, 
the Gala for fishing purposes may be said to end at Torwoodlee. At Gala-foot, in the Tweed, it is triumphantly asserted by the mill-owners and the Border Advertiser, that there is a very superior roe-cast, which merely proves that when the river is flooded the fresh water from the hills is sufficient to dilute the chemicals from the mills. We have not yet heard that trout are very fond of muriatic acid, and we conceive it to be highly desirable, not only for the sake of anglers, but for the sake of the community at large, that every precaution should be taken to prevent the pollutions of factories from mingling with the pure streams of the border. At Hawick, numerous efforts have been made to prevent the defilements, by running the dyes and other chemical preparations used into pits, where they stand until the poisonous stuffs precipitate; but the manufacturers grumble loudly, and try to evade what they ought to be forced to do, at whatever cost of trouble or money. We are not aware that as yet any similar efforts have been made at Galashiels. At that town there is a cauld so high as to prevent salmon from ascending the stream to spawn; and so the angler in this river may fish the year round without fear of killing forbidden fish.

The vale of Gala is not very picturesque, nor is it very fruitful in song or tradition. Burns has celebrated its " braw braw lads." It was anciently denominated Wedale-the Vale of Wo-for what reason is not exactly clear, but probably on account of some deadly battle which left the sound of lamentation and weeping on the banks of the Gala. The vale was formerly church property, and a chapel stond near Stow. Tor- 
woodlee, the seat of the Pringles, a border clan of some note, is on the banks of the Gala, about two miles above Galashiels; and near it are the castles of Buckholm and Blindlee, from which it is said that two inveterate enemies of the owner of Torwoodlee used to watch him in the time of Charles the Second (Pringle being a Covenanter), in order to detect some symptom of disaffection to the Government. Galashiels is an energetic manufacturing town; and its inhabitants have much of the old border spirit smongst them. Hence the poaching.

The Leader rises amongst the western skirts of the Lammermoors, from the recesses of which hills it draws its supplies, although the greater part of its course is through a low-lying and rich country. The upper waters of the Leader can be best commanded from Carfrae-Mill Inn, which is on the old coach-road from Edinburgh to Kelso, but which is now rather difficult of access. The two most convenient modes of getting to the Leader are by walking or driving nearly six miles over the hills from Stow, in the vale of Gala, to Lauder, and by taking the omnibus, which runs twice a-day from Melrose to Earlston, a distance of seven miles. We believe, however, that the head of the Leader might be readily reached by an adventurous pedestrian from Heriot station, who might try to find a road for himself across four miles of hilly country; but until that path has been discovered, we must be content to recommend our readers to go to Lauder, and fish up to Carfrae-Mill. About that point the Leader separates into two streams, which are each again si- 
milarly divided; and as they are all about a size, it is difficult to say which is the proper source of the Leader. The fishing in them is good, and the trouts of excellent quality, sometimes of very good size.

From Carfrae-Mill for about three miles downwards the Leader is open to the public, and the trouting is excellent. The trout, however, are small, the streams being rapid and thin; but if the angler does not object to an average of five or six to the pound, he may find good sport here. A mile above Thirlstane Castle, the seat of the Earl of Lauderdale, his lordship-the son, we believe, of the man who was so strong a Jacobin and advocate of equality and fraternity-claims possession of the river, and strictly preserves it for about two miles to Lauder Bridge. Some of the profane vulgar, however, who have penetrated into his lordship's sacred preserves, inform us that the trout, although very numerous in this piece of water, are very small, from the fact of there being too many of them for the food that is to be had. A little more fishing would have the effect of increasing their size, and would thus make the sport better. A little below Carfrae, the Wharplaw-burn, a small hill-stream, enters the Leader, and in the middle of the Thirlestane preserve, Earncleuchwater also comes in. The latter stream is reputed to be worth angling in. Below Lauder Brig there is a stretch of nearly four miles of water in which the public may enjoy their sport uninterruptedly, and in the greater part of this the fishing is very good. Below St. Leonard's Mill, a mile and a half from Lauder brig, the trout are rather scarcer than in the water above, but they average five or six ounces in weight, and will 
repay careful fishing. The Leader is a stream exceedingly well suited for the use of the minnow. Near St. Leonard's the Boon-water comes in from the east, and although but a small stream, it contains plenty of good-sized trout. Two of the streams which unite to form it, Blyth-water and the Boondreigh, come rapidly down from the Lammermoors, while another oozes out from the moors of Gordon, and has pools in which there are trouts of large size.

This part of the Leader can of course be very conveniently fished from Lauder, which is a small old "burrows-toon," with a comfortable inn. Over Lauder Brig, the Scotch Barons on one occasion hanged, in their rough way, all King James the Third's favourites, because his Majesty took more delight in music and the fine arts, than in hunting, hawking, and fighting. Such tastes were looked upon as disgraceful in a Scottish King; for although his grandfather was a sweet poet, and wrote The King's Quhair, he was also a politic ruler, and a hard rider of the border nobles and the Highland chiefs, and it was for that that they finally murdered him cruelly at Perth. The highspirited nobles, who may be pardoned for their contempt of science and art, seeing that they were too ignorant to know anything about these things, could not brook that a "mason," as Pitscottie terms one Cochrane an architect, who was made Earl of Mar, should presume to rank with them,-so after a midnight council in the kirk of Lauder, at which, according to the well-known story of the old Scots historian, the stalwart Earl of Angus undertook to "bell the cat," the favourites were seized, and as we have said, hung 
over the bridge in halters. It is an unfortunate feature in Scottish history, that the aristocracy of the country always appear as about the worst in the world. They ought to have been rather advanced in civilisation and patriotism, it might have been thought, under the good and wise King Alexander III., but as soon as the English aggression commenced after his death, they disgracefully yielded to the invader, caring for nothing but to keep their lands. And so they always show throughout. As mean and greedy as they were proud and ignorant, they had only the redeeming quality of bravery in the field. From the time of the war of Independence, when they were so basely jealous of Wallace, and gave such laggard support to Bruce, there are singularly few stories of gentle chivalry in the annals of the Scottish nobility. At the Reformation they pillaged the church far more ruthlessly even than their compeers in England; they adopted readily the religion which the Charles's fruitlessly tried to thrust down the throats of the people of Scotland; they sold their ancient Parliament for English gold; even when they went out with Prince Charlie, they usually left a member of the family at home to take the other side, so that whoever might win, the lands might be kept! In our own day, they are aliens from the national religion, and are personally trying to spread Episcopacy throughout the land; while at county meetings and on the hustings they are constantly and mysterionsly bawling about the support of the Established Presbyterian Church, in which they somehow affect the deepest interest, though giving it the go-by on Sundays.

Feeling slightly relieved by the above expectora. 
tion of spleen-prodnced (who knows?) by the recollection of the contemptible preserving spirit that actuates so many land-owners in Lauderdale-we proceed to our work; but before leaving Lauder we must pay a passing tribute to one who is not a noble, but is, we believe, something of a tinker, and a "gut-scraper" at fairs. James Baillie of Lauder, however, is probably the best fly-fisher in the world. We do not know that he has much more book-learning than Archibald Bellthe-Cat, nor are his abilities, either as tinker or fiddler, much to be talked of; but for several months in the year he is able, by a few hours' tront-frshing in the day, to keep a wife and family, and can pick ont from 12 to 20 pounds of fish, where most people would find a difficulty in getting any at all. $\mathrm{He}$ is weak in constitution, and is afraid of cold, or of wetting his feet; so he usually devotes only the forenoon to the Leader or the Gala. But necessity has sharpened his angling faculties, and so perfected his skill, that in that time he can fill his basket. Whether he really was the first to find out the advantages of fly-fishing up-stream, we do not know; but it is certain that he is the most efficient practiser of the method, and we believe that he gave the hint to Stewart, who has, after personally testing its benefits, brought it out in the volume from which we have made so many quotations. There are two brothers of the name of Dryden, of Hawick, who rival James as anglers, but not in the department of fly-fishing; - we believe, indeed, that he hardly practises any other mode. Casting up-stream, with carefully "waled" gut, and flies dressed lightly upon the hook, James Baillie is unsurpassed. 
At Blainslee Bridge, the freedom of fishing is again interfered with. The water skirting the estate of Chapple nsed to be open, but a new owner has arisen who knows not the sons of Izaak, and who takes after the magnate of the district by preserving. The owner on the other side is said to be a little more liberal. After these comes the Carrolside-tvater, also strictly preserved. This part of the water is about the best in the whole river, and, as we have hinted before, the only penalty that can be exacted for fishing in preserves is the amount of damage caused by the trespass. Verb. Sap.-never make any inquiries about boundaries. A little above the village of Earlston, the restrictions of grasping landowners are relaxed, and there is about a mile of water open. We suspect the villagers pay a good deal of attention to it. Earlston, as we have mentioned, has a 'bus running daily to Melrose. The remaining two miles of the Leader comprise the Cowdenknowes and the Drygrange waters, both of which are gamekeepered. A dam-dyke at Leader-foot prevents salmon from ascending the stream.

But, if we cannot fish in the rest of the Leader, we may at least be allowed to lie down on its banks and call to mind the associations that cling to them. We have recommended the angler to be diligent in his vocation, and, especially when there is a "take," to direct all his energies to the capture of lisi. "Time 's troots," is the pithy maxim of a friend of ours. But when the trout give up rising to the fly or seizing the worm, let the fisher not scruple to rest himself, eat his luncheon, and try his flask. And if he should chance to be on Lcader-side, near the beautiful 
village of Earlston, why not lie down and dream of the old times when Thomas the Rhymer was pursuing his liaison with the Queen of Fairyland;-when " a knight and a lady bright had a true tryst amang the broom," and the foolish knight fell asleep, and the lady, softly approaching, kissed his lips, and passed away unscathed from the perilous meeting against which her wily nurse had warned her;-or when the love-passages of the shepherdess and her swain gave the cue to that sweetest of border melodies, "The Broom o' the Cowdenknowes?" In the pretty haugh below Earlston are the ruins of True Thomas's tower ; behind, and farther down the river, are the Cowdenknowes and their bonny bonny broom. Whether the prophet had as much honour in his own country in his own time as he had afterwards, who can tell?for no one knows when he lived. But there are the remains of his ancient hall of Ercildoune, testifying to the tradition of his existence, although hardly, like the bricks of Jack Cade's house, "alive to this day" to relate its particulars. The stream of time was but a burn when Thomas sat its banks, and a deal of Scotch mist is hanging over its recesses and windings. But the legend is a glorious one. And how the green and golden livery of the broom on those knowes is mellowed and beautified by that one simple song! When you get back to the George at Melrose to-night you may find some one to sing it to you.

" $O$ the broom, the bonny bonny broom,

The broom o' the Cowdenknowes;

I wish I were there with my dear lad,

With his pipe and my ewes."

The names of the locality are strung together in a 
ERCILDOUNE-THOMAS THE RHYMER. 139

curious old song, by some one who called himself " Minstrel Burn," which Sir Walter Scott was fond of quoting-

$$
\begin{aligned}
& \text { "Sing Ercildoune and Cowdenknowes, } \\
& \text { Where Homes had ance commanding, } \\
& \text { And Drygrange wi' the milk white ewes, } \\
& \text { 'Twixt Tweed and Leader standing. }
\end{aligned}
$$

For many a place stands in hard case,

Where blythe folks kent nae sorrow, Wi' Homes that dwelt on Leader side, And Scotts that dwelt on Yarrow."

The bare high knoll that you see standing to the south-east of Earlston is Sandyknowe, where Scott was brought up, and on it are the remains of Smailholm Tower, the scene of his ballad of "The Eve of St. John."

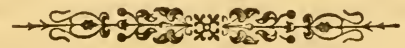


CHAPTER VI.

THE TEVIOT AND ITS TRIBUTARIES.

"Sweet Teviot! on thy silver tide

The glaring bale-fires blaze no more;

No longer steel-clad warriors ride

Along thy ${ }_{2}$ wild and willowed shore."

The Lay of the Last Minstrel.

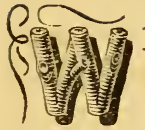

$\mathrm{E}$ do not know that in a single old border ballad there is mention made of any kind of fishing. Yet, when the deer were getting scarce, as undoubtedly they must have been in the sixteenth century, what sport could have been more congenial to the Scotts, Elliots, Kerrs, Turnbulls, and Rutherfords of Teviotdale and Jed Forest, in the intervals of their feuds and forays, than either leistering or angling for salmon in the numerous streams that traverse Roxburghshire? There is no record, so far as we are aware, of the period when angling was introduced into Scotland-if we recollect rightly, the first mention of the "wande" as an instrument of killing fish is in a statute passsed during the reign of Queen Mary; but it is certain, from Dame Juliana Berners' "Treatise of Fysshinge with an Angle," printed in 1496, that it was practised in England a century previously, and doubtless also it was a common recreation in Scotland. Sir William Wallace, as we learn from Blind Harry, diverted himself by fishing 
with a pout-net in Irvine-water, and, when interrupted in his sport (as Scotch anglers too often are, even now-a-days, by Englishmen, or at least by Englishmen's gamekeepers) he as usual easily made "a Scots poult-staff foil five English swords," killing three men and making the other two run for it! We may conclude from this that there was no angling then,-for who can suppose that if the hero knew the use of a fishing-rod he would have descended to a pout-net? Still it showed the spirit of fishing alive in Scotland, and it is not likely that that spirit would die out; in fact it seems to have become a sort of instinct, especially on the Borders, so long has it been identified with the habits of Scotchmen. Wherefore, then, this omission in the ballads? We leave the question to future investigators. We might almost say there is a cognate puzzle in the absence of any special praise of drinking in the old poetry. "Fuddling," which in modern times has been so much and so improperly conjoined with " fishing," is in the ballads only mentioned incidentally, -as when it is stated that the monarch's commands came to Sir Patrick Spens, or news of an English raid came to Bucclench, as they were sitting at table birling their bottle; or that "late at e'en, drinking the wine, and e'er they paid the lawin"," the combat was set that ended so bloodily in the dowie houms o' Yarrow. The lads of Wamphray, in the exuberance of their triumph, declare that they will "hae a pint at Wamphray gate"-a Dumfriesshire ale-house; and the very emphasis they give to that exceedingly moderate proposal might support the inference that they were rather addicted to teetotalism. 
We happen to know, however, from other sources, that such an hypothesis would scarcely consist with authentic facts; and that a "Hawick gill" was even more frequently in request in those days than in our own. Wherefore, then, are there no old border drinking songs? Frankly, we do not know, and have not time to guess. Perhaps the old minstrels thought that their profession of recording the loves, wars, and thievings of the border chiefs would be lowered by singing of the bottle, and left that to pert Edinburgh lawyers who followed the Circuit, such as the one who declares, in a highly humorous but rather equivocal ditty, in the praise of "Jonet Reid, Marion White, and Jean Violet, being slicht women and taverners," that

"This song of thrie lasses

Was made aboon glasses

In Jedburgh at the Justiciair."

But whether or not there was much fishing or fuddling in Roxburghshire three hundred years ago, there is a fair proportion of both now, and

"The men of pleasant Tiviedale,

Fast by the river Tweed,"

can handle both the rod and the glass like adepts.

The Teviot rises near Mosspaul on the borders of Roxburghshire and Dumfriesshire. An inn at this place, on the Hawick and Carlisle road, gives the angler the opportunity of fishing the higher tributaries and hill-burns, which combine to form the river in its early stages. These have the usual character of such burns, - the trout small but plentiful, and the green hills and bare moors pleasant in summer and autumn, when such streams are most worth fishing. The first 
notable tributary of the Teviot is the Allan, which from the south winds through some very beautiful pastoral scenery of which the chief feature is the Pens or laws-detached conical hills, standing by themselves. It joins the main stream about four miles above Hawick, and from its retired character is, we should imagine, very little fished. Borthwick-water next enters, from the north-a rocky and shallow tor. rent, with some good pools towards its head. Branxholm Castle, which was the principal hold of the Scotts three hundred years ago, and is indeed the scene of the Lay, stands on the side of the Teviot halfway between where the Allan and the Borthwick join. The old peel of Goldielands stands nearly opposite the mouth of the Borthwick; and overhanging the deep and rugged ravine of one of the little tributaries of that stream is the ruinous Tower of Harden, where another and famous branch of the Scotts maintained themselves, in great measure at their neighbours' expense. We believe Lord Polwarth is the representative of this line; and it was from it also that Sir Walter Scott drew his lineage. The Teviot itself is much harassed by the Hawick mechanics,-in winter with all sorts of contrivances for the capture of the spawning bull-trout, which run up it in immense numbers, and in summer with the harry-water-net for river trout, for which ready sale can always be found. From Branxholm upwards, however, good fishing may be had. The road from Hawick to Carlisle follows the vale of the Teviot for nearly ten miles, and a coach runs daily each way between these places; we fear, however, it is not so timed as to be of much use to the 
angler, as it passes both down and up the Teviot abont the middle of the day. Hawick and its suburb, Wilton, make together a town of nearly 10,000 inhabitants, the head-quarters of the manufacturing industry of the south of Scotland. It is a place of great antiquity. In its inns there is of course ample accommodation for travellers. Within a few weeks of our writing, it will be decided by Parliament whether a railway to unite Hawick with Carlisle shall go by the Slitrigg and the Liddel, in continuation of the North British line, or by the Teviot, Ewes, and Esk, forming a branch from the Caledonian. Either way, a railway throngh the district will be of advantage to the angler; but undoubtedly the former, opening up the Liddel, which as an angling-stream is greatly superior to the Esk, will be much the preferable.

The Slitrigg enters the Teviot just at Hawick, intersecting the upper part of the town. The course of this stream is about ten miles, in greater part very hilly and rocky. Near its source its banks are bare; and though there are fine woods around Stobbs Castle, a seat of the Elliotts, it is chiefly to its ruggedness that it owes its picturesqueness. It is a rapid water, and is well stocked with fish that seldom attain a large size. It is greatly frequented by bull-trouts in spawning-time.

Below Hawick, the vale of the Teviot expands, and its subsequent course of thirty miles is through a rich and beautiful country. We are not exactly informed as to what parts of the river are attempted to be preserved, but we believe restrictions have been placed upon the angling of late years by several landowners. 
Fishing in preserved water is not, however, amongst the deadly sins, and we do not suppose that the angler will experience much annoyance, as it is probably chiefly with a view to check the incursions of the Hawick weavers that prohibition has been resorted to. Partly from the assiduous attentions of these sons of industry, and partly from the deleterious character of the chemical stuffs which are allowed to escape from the manufactories - though we believe measures have lately been taken to abate this nuisance-the angling in the Teviot for a few miles below Hawick is not very choice in its character. It is not perhaps until it is joined by the Rule, seven miles from Hawick, that it it becomes really worthy of the reputation which it enjoys amongst anglers. Under the shadow of Minto Castle, the seat of the nobleman who framed the Act that is held in terrorem over them, it is to be expected that the wicked netters from Hawick should cease from troubling.

The Rule is another swiftly-flowing tributary from the hills, the velocity and rockiness of which are not favourable to the growth in size of its finny habitants. They are, however, very numerous, and have greatly increased since the ravages of the netters have been restrained. It is a good worm stream, but requires careful fishing from the number of bushes overhanging it.

In following the Teviot, however, we have already passed the village of Denholm, the birthplace of a man who deserves notice from us, if for nothing else than that he has embalmed the hills and vales, woods and streams of Roxburghshire in beautiful verse. Dr. John Leyden, the author of "Scenes of Infancy," was born 
here in 1775 , of peasant parentage; and but that his career was cut short by untimely death, there is every reason to believe that he would have made for himself an eminent name. His parents were ambitious that he should "wag his pow in a poopit," and so, his parishschool curriculum over, he went to Edinburgh University, and even became a probationer of the Church. But he had other longings after literature and science, and it was while he was poring over old books, perched on a library-ladder, that he was discovered by a friend of Walter Scott to have an extraordinary amount of border and ballad lore. Scott was preparing the Minstrelsy of the Scottish Borders, and Leyden on being introduced to him immediately became his friend and zealous coadjutor. He undoubtedly rendered great help in the work, besides contributing several original ballads and the beautiful poem upon Flodden field. In a letter, written in 1800, Scott relates-" An interesting fragment had been obtained of an ancient historical ballad; but the remainder, to the great disturbance of the editor and his coadjutor, was not to be recovered. Two days afterwards, while the editor was sitting with some company after dinner, a sound was heard at a distance like that of the whistling of a tempest through the torn rigging of the vessel which scuds before it. The sounds increased as they approached more near; and Leyden (to the great astonishment of such of the guests as did not know him) burst into the room, chaunting the desiderated ballad with the most enthusiatic gestures, and all the energy of what he used to call the saw-tones of his voice. It turned out that he had walked between forty and fifty miles and back 
again for the sole purpose of visiting an old person who possessed this precious remnant of antiquity." Muscular energy and animal spirits were indeed as chiracteristic of Leyden as his strong mental faculties and indomitable resolution. He delighted in teasing" poor peevish Ritson-the learned antiquarian-when he visited Scott at Lasswade; and for the purpose of horrifying the nervous vegetarian, manfully bolted a pound of raw beef-steak one day at dinner, declaring that it was the only proper food of man! Such a marn could make his way in the world anywhere; and when he was sent out to Madras, chiefly through Scott's friendly influence, nobody seems to have been surprised that in a year or two he became first a professor in the Bengal College at Calcutta, and afterwards one of the principal Judges of the Presidency. He died in 1811 of fever. while engaged in a scientific expedition to Java, just as he was becoming the first Orientalist of his day, and was laying the foundation for future honours. Nany warm and worthy friendships died "with Leyden in "s distant land," and Sir Walter mourned him in one of those beautiful Epistles that open the cantos in Marmion, and again in The Lord of the Isles.*

* In a note to The Antiquary, the following example of the native spirit sticking to Leyden in India is given :-

"The account of the ready patriotism displayed by the country on this occasion [the false alarm of invasion in 1804] warmed the hearts of Scottishmen in every corner of the world. It reached the ears of the well-known Dr. Leyden, whose enthusiastic love of Scotland, and of his own district of Teviotdale, formed a distinguished part of his character. The account, which was read to him on a sick-bed, stated (very truly) that the different corps, on arriving at their alarm-posts, announced 
The banks of the Teviot are very beautiful in the neighbourhood of Minto, with its wooded grounds, and the picturesque crags "where Barnhill hewed his bed of flint." There is a good deal of wood on the lower part of the Teviot, but not such as to interfere with the angler, who has now a pretty broad river, with alternate pools and streams. There are various places in the district where entertainment may be had, particularly at Ancrum; but the whole of this part of the Teviot, as well as the neighbouring 'tributaries, may very conveniently be fished from Jedburgh.

The Ale is the next accession which the main river receives. It flows in from the west, its sources, as we have already mentioned, being a number of lochs in the high lands of Selkirkshire. These lochs are Kingsmoor, Alemoor, and Hellmoor, on Ale-water proper, the Shaws-lochs near the head of Todrigg-burn, and Akermoor-loch, out of which Blindsclengh-burn flows, with some others of smaller dimensions, Essenside,

themselves by their music playing the tunes peculiar to their own districts, many of which have been gathering signals for centuries. It was particularly remembered that the Liddesdale men entered Kelso playing the lively tune-

"O wha dare meddle wi' me, And wha dare meddle wi' me? My name it is little Jock Ellint, And wha dare meddle wi' me?"

The patient was so delighted with this display of ancient border spirit, that he sprung up in his bed, and began to sing the old song with such vehemence of action and voice, that his attendants, ignorant of the cause of his excitation, concluded that the fever had taken possession of his brain; and it was only the entry of another Borderer, Sir John Nalcolm, and the explanation which he was well qualified to give, that prevented them from resorting to means of medical coercion." 
Shielswood, Headshaw, and Ashkirk, as the reservoirs of other tributaries. It is stated that in some of them trouts are scarce, there being abundance of pike and perch, but there are, we believe, numbers in both Alemoor and Hellmoor, as well as in Clearburn, in the neighbourhood, the outlet of which is to the Ettrick; and they are rarely visited, so may have attractions for those who seek "society where none intrude." They may be attained from either Tushilaw on the Ettrick, or from Hawick; but if any kind of "upputting" can be found at Ashkirk-of which we are ignorant-about five miles from Hawick, it would naturally be the most suitable point from which to command them, and the head of Ale-water. The upper part of the Ale is, we believe, well worth making an effort to get at; and throughout this little stream contains capital trout and affords good sport, especially after a flood. By a sudden leap at some linns near its source, it saves itself the constant incline that makes so many of the streams in Roxburghshire too rapid and shallow for the production of weighty trouts, and thus it runs into pools that afford an occasional pounder to the angler. New Belses station, which is five miles beyond Newton Junction, at which the line to Hawick branches off, is within easy reach of the Ale, about the middle of its course ; and the Edinburgh angler could thus accomplish a day's fishing in this pretty little water by leaving home in the morning and returning at night. There is an inn at Lilliesleaf where an angler who wished to stay might find accommodation. At Ancrum, the lower part of the Ale is quite handy; and a bend which it makes about three 
miles above that village is within walking distance of St. Boswell's. John Younger, of that place, was bred on Ale-water, and in the last verses of his which we have seen, he recalls to mind his primary step to the angling excellence which he has since attained :-

"Still, as in a dream, I can see the first flee

George Grey in the Ayle-water kindly gae me:

Such pleasures of hope as it raised in my breast

Hae never by poet on earth been exprest.

'Where was ye a' day, laddie-what been about ?'

When joyfu' I held out my first little trout:

To utter the feelings a' language is rain-

But just it was what I can ne'er feel again,

Unless in idea: as we rub in life's rust

Wearing down into age-ere we drop in the dustThe thoughts of a new birth may weel mak us fain,

Were it only a hope to be younglings again!"

Rather a pawkic touch that of John's about the new birth, we are afraid.

A little way from Ancrum is the field of Ancrum Moor or Lilliard's Edge, where a savage English foray upon Melrose and Teviotdlale in $\mathbf{1 5 4 5}$ was amply avenged by the Earl of Angus, who followed the retiring army.

About trro miles below the mouth of the Ale, the Jed enters the Teviot from the south. For the greater part of its course, the angling in the Jed is much interrupted by trees, but towards its source it has a good deal of the usual character of hill-waters. After it has flowed about five miles, and been increased by the Black and Carter burns, it bends pleasantly round Southdean kirk and manse, where James Thomson, the poet of the Seasons, was brought up, and where it is said he planned and partly wrote "Winter." His father was minister of the parish, having been "translated" hither from 
Ednam, where, on the banks of the Eden, Thomson was born. The poet could not miss being an angler, reared as he was by the side of the Jed, and it was doubtless the remembrance of his boyish exploits that prompted his admirable description of fly-fishing, in "Spring:"

" Just in the dubious point, where with the pool Is mixed the trembling stream, or where it boils Around the stone, or from the hollow'd bank Reverted, plays in undulating flow :

There throw, nice judging, the delusive fly; And as you lead it round in artful curves, With eye attentive mark the springing game, Straight as above the surface of the flood They wanton rise, or, urged by hunger, leap, Then fix witls gentle twitch the barbed hook. Some lightl And to the shelving shore slow dragging some, With various hand proportioned to their force. If yet too young and easily deceived

A worthless prey searce bends your pliant rod, Him, piteous of his youth, and the short space He has enjoyed the vital light of hearen, Soft disengage, and back into the stream The speekled eaptire throw. But should you lure From his dark haunt beneath the tangled roots Of pendent trees, the monarch of the brook, Behoves you then to ply your finest art.

Long time he, following cautious, scans the fly, And oft attempts to seize it, but as oft The dimpled water speaks his jealous fear. At last, whilst haply o'er the shaded sun Passes a clond, he desperate takes the death With sullen plunge. At once he darts along, Deep-struck, and runs out all the lengthened liue. Then seeks the farthest ooze, the sheltering weed, The cavern'd bank, his old secure abode; And flies aloft, and flounces round the pool, Indignant of the guile. With yielding hand, That feels him still, yet to his furious course 
Gives way, you, now retiring, following now Across the stream, exhaust his idle rage, Till, floating broad upon his breathless side, And to his fate abandoned, to the shore You gaily drag your unresisting prize."

This is angling in the Jed at Southdean, not in the Thames at Richmond or Twickenham; and it is plain that the whole of the Seasons receive their colouring from impressions made upon the poet's mind in his border life.

The trout of the Jed are of good size, and of a high character from the frying-pan point of view. The trees that make its banks so picturesque are not so objectionable to the fly-fisher who casts up-stream, seeing that he needs less room behind him for the swing of his line, as to the one who casts straight across; and to the worm-fisher, who does not require to use a long line, they are still less objectionable. But if an angler finds himself in any case interrupted by trees,-mistaking his distances in casting, failing to perceive some slight projecting branch that intervenes between the point where he wishes his fly to fall, constantly getting fast, trying in vain to get his line down, then giving it a tug that breaks it and renders it necessary for him to construct a new one that is shortly to share the fate of its predecessor, - we most earnestly beseech him to keep his temper. If he gets hot and begins to swear, and in his eager hurry to make up for lost time verifies the maxim that "the more haste the less speed," we advise him to sit down, take out his handkerchief and wipe his face, then to examine the contents of his pocket-pistol, and coolly reflect what is best to be done. If he goes on without doing so, he will probably en- 
tirely lose not only his temper but his time; he will get into a furious passion, and will obstinately declare to himself that he will be dee'd if he be beaten by trees, let them grow ever so thickly or perversely. And so he will get worse and worse; keeping the recording angel busy for a whole forenoon, the perspiration pouring over his (the angler's, not the angel's) face, his pocket-book rapidly thinning of his favourite flies, and people passing will wonder how the fisher's art should ever have been called the Contemplative Man's Recreation. We are drawing no fancy picture, but what we ourselves, in common with hundreds, have experienced. There is nothing so tempting as a cast that shall bring your fly under some overhanging branch, where imagination depicts a monster ready to seize it: but if the fly can't be got there, why should you persist in trying it? Flee the temptation-walk a few miles if necessary to some point where you have water free from foliage-and the result will be that you will preserve your serenity and probably fill your basket.

Who does not admire trees and rivers in combination; but let us add, why should the wood and water crowd each other? To be an angler, Burns, in his petition for trees to adorn the banks of the Bruar, most unaccountably neglected to stipulate that they should not approach within a dozen yards of the water's edge. Overlooking this unfortunate feature in its sylvan adornment, that it sadly interrupts angling, it must be acknowledged that the Jed for the last few miles of its course is preëminently beantiful.

JEDBURGH itself is an ancient town, that for centuries had to bide the brunt of southern invasion, which was 
all the more ruthless in the latter period of the national wars, when Englishmen had begun to lose respect for church property, which had formerly been held sacred even in the most ferocious inroads. After Henry VIII. had let the Southern nobles taste the blood of the church, as it were, the noble Abbey of Jedburgh began to suffer in the forays until it was entirely reduced to dilapidation in 1545. It is still, however, a fine monument of ecclesiastical art. There are a great number of old fortresses and other antiquities in the neighbourhood of Jedburgh ; and at Hundalee, Lintlee, and Mossburnford, the rocky sides of the Jed are excavated so as to form hiding-places, probably for women, children, and other valuables, in times of tronble. The burghers of Jedburgh, however, were always ready to give as good as they got; their peculiarly inverted method of carrying out criminal law has passed into a proverb; and at the last great border battle, the Raid of the Reidswire, they came in pretty effectually, and turned the day in favour of the Scotch. The town in its modern character is a "pleasant habitation," and is the best place from which to fish the Teviot and its lower tributaries. Besides the Rule, the Jed, and the Ale, it gives command of the Oxnam, and allows of a stretch to the Kale. The Oxnam enters the Teviot from the same side, about two miles below the confluence of the Jed. It is a small stream, and is not, we believe, much distinguished amongst the anglers of the district. Not so the Kale, however, the next and last tributary which the Teviot receives. Its trout are numerous, of fair size, and of excellent quality. The upper part of it may be most conveniently fished from Hounam, where the 
angler will find accommodation at the village inn. The lower part may be reached readily from either the Old Ormiston or the Nisbet station on the Jedburgh line, -and the angler will find it a pretty hard day's work to fish thence up to Hounam, missing all the woody places, there being plenty of water with grassy banks. The head of the Bowmont is within reach of Hounam.

Below Mounteviot, when salmon were more plentiful than they are now, there were several casts in the Teviot where a number of fish were got with the rod every year. A favourable autumn flood always brings a fer grilses into the pools of the Teviot, but they are thinly distributed, and the angler must seldom be sanguine of success with his salmon-rod. Great numbers of kelts have, however, hitherto been killed in this river, in the spring, with the rod; and, before they took a thought and mended, the kelt-killing gentry of Roxburghshire to whom we have formerly alluded used to commit deadly ravages in it with the leister. In the spring of 1857 a feat in kelt-fishing was performed in the lower part of the Teviot by MIr. Purves of Kelso. We have mislaid the paragraph from the Kelso papers which chronicled the deed; but it was, we think, from Heaton-mill cauld, near Roxburgh, that in a few hours one afternoon he took eight fish, weighing altogether $126 \mathrm{lbs}$. Two of them, kelts though they were, weighed $26 \mathrm{lbs}$. each, two others were $16 \mathrm{lbs}$., and the rest smaller. It was on a frosty day, and Mr. Purves was angling with minnow. In the same piece of water Mr. Stoddart has accomplished some of his most remarkable victories. We have incidentally alluded to his eel, which took a gorge-bait with which he was trolling for pike, 
swallowed it, ran off in extraordinary style, and finally, finding no other way of escape, bolted the whole nine inches of brass wire, and bit through the line. Much amazed, Mr. Stoddart threw in six set-lines, each with a trout and wire-armed hook at the end, and went on his way trouting. When he returned, and proceeded to draw his lines, he found the first five docked of their bait and hook, the whole having been swallowed and the cords bit through by some monster, as had happened to his trolling-line; but at the end of the sixth, dead and motionless, was a huge eel with the whole of the lost gorge-hooks, brass-wire and all, in its maw, having been choked in its attempt to swallow the seventh! Mr. Stoddart most unluckily did not weigh his prize, but estimated it at $20 \mathrm{lbs}$. We have searched for, but have been unable to find, this singular circumstance recorded in the last edition of The Angler's Companion; we are certain, however, that it was in the first. In the last edition of that book-which is really the most complete and interesting, as it is about the bestwritten, of angling-works-we find set forth, however, a very remarkable mode of grilse-fishing in Heatonmill cauld, in which, with a worm and float, in the mode of school-boys bobbing for perch, on a bright day, with the water low, clear, and calm, Mr. Stoddart killed a "noble grilse" out of a shoal of about a dozen which were visible sailing about in the pool.

In April and May the Teviot swarms with smolts, both of the salar and of the eriox, so that the angler must be careful. He cannot possibly avoid hooking one occasionally; and if he finds, when he has hooked one, that a sharp twitch will not suffice to disengage 
the hook from its mouth, he ought to pull the smolt out as quickly as he likes, but not with a jerk that may involve the risk of killing or seriously injuring it, should it fall on a stone.

"Take it up tenderly,

Lift it with care, Fashioned so slenderly Young and so fair;"

and return it gently to the water, hoping that it may be your luck in the future, if not to kill it, at least to pay your "devours" to it as a grilse or salmon at some friendly board or Tweedside "kettle."

The lower part of the Teviot, from the mouth of the Jed downwards to near Roxburgh, is decidedly the best part of the river for trouting. The trout are larger than in the upper streams, and, although capricious, by the lise of the finest gut and lightly-made flies of the more sober hues, or of well-scoured worms in summer, bountiful returns for skill and labour may often be obtained. Roxburgh station receives the angler exactly at the part of the river where it is most desirable to begin-and, according to the arrangement of the trains, about seven hours fishing may be obtained in the Teviot by any one leaving Edinburgh in the morning and returning to it at night.

In all the still pools below Mounteviot-from ponds at which they are said originally to have come-there are considerable numbers of pike; which, unlike these fish in most lochs or other rivers, take readily in early spring, and probably throughout almost the whole year. They are of good quality as compared with most river-pike, and were at one time increasing so rapidly 
that their depredations caused considerable fears for the future of the lower part of the Teviot as a troutingstream. A lucky flood, however, carried numbers of them off, and cleared out some of their holds and haunts; and it seems certain that the floods from the Roxburghshire hills are far too frequent and heavy to allow them ever to become so abundant, or their weedy refuges to become so secure, as to give the esox the ascendancy over the salmo in this famous river. Pike are frequently carried, even by ordinary floods, down the Tweed from the Teviot, the Leet, and the Till, probably even to the sea; for they have been caught in the salmon-nets within the tide-way. In no part of the main river, however, have they fixed their habitation. At Coldstream, a few years ago, a pike was caught in the Tweed by a worm-fisher, in a stream-a circumstance, so far as we know, altogether singular in the history of pike-fishing. Heaton-mill cauld is also about the best cast for pike in the Teviot.

There are perch in the Teviot, and we believe they are sometimes taken of a very large size, even up to three and four pounds. The minnow, either spun in the ordinary way, or angled with alive, is a more tempting bait for large perch in rivers than in ponds. But little attention, however, is paid to this kind of fishing by border anglers.

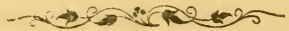




\section{(159)}

\section{CHAPTER VII.}

THE WHITADDER AND BLACKADDER.

6 HESE Berwickshire Twins will stand compais rison with any trouting-streams in the south of Scotland. The one is fair and gravelly, with rattling streams, and sometimes rocky banks; the other black but comely, sleeping in its alluvial bed amongst the moors, and breeding big trouts that are as strong and sportive in the water as they are flavoury on the table. Both come from the same hills, yet no two streams differ more in character. It is hard to tell which is the preferable; and the best way of solving the difficulty is to spend a summer in the skirts of the Lammermoors, and take them "week about."

The Whitadder rises at the White Well, near Johnsclench, in Haddingtonshire, and for the first fifteen miles of its course winds its way through the bare valleys of the Lammermoors, the heathy sides of the hills being relieved and variegated by pleasant patches of green. In the first five or six miles of its course it receives but insignificant contributions from a few burns; but it and they are all swarming with small trout. Above Millknow, in a flood, a boy with a pin may slay his dozens, and at all times the expert angler may fill his pannier, if it is of reasonable size, with trout-a few of decent proportions amongst them. 
At Millknow the Whitadder is joined by the Fasney, a rocky and heathery-edged stream, than which there is no water that we know of that yields a greater quantity of trout to the fisher. Its bleak recesses are indeed but seldom explored, save by the shepherd looking after his flocks. The farm-house of Priestlaw stands near its mouth, but there is not another house or hut on its banks throughout its whole course. It is five miles, at its nearest point, from any inn or village, and that village is eight miles from any railway, or place reached by any public conveyance. Probably, since time began, no net has ever been drawn through it, unless a pout-net for sport in a flood; for there is no temptation in the way of a market for the trout, even if there were poachers ready with their implements. But indeed its rugged bottom would not allow of the effective use of any of the more deadly engines for destroying river-trout. We have never seen any drains-save from Priestlaw farm-running the rain too hastily from the hills into the stream-(a cause, by the way, which we have not yet mentioned, of the decrease of trouts and the falling off in angling.) While, therefore, there are of almost all the rivers which we have visited, complaints of evils that have reduced their trouting capabilities-over-fishing, netting, factory filth, hill-drainage-here is one free from them all, that is as good now as it was a hundred years ago, and that will probably continue so for ever. The desolate Fasney will, we trust, be an exception to the " progress of the age," for to our mind it is " so aptly formed by Nature" as to be susceptible of no improvement. There is one drawback, indeed-the trout of 
the Fasney are of the regular heather-burn species. The stream is a hill-burn magnified, and its inhabitants are black, large-headed, powerful of jaw, and poor of flesh. They are not, on the whole, so small as the trout usually are in such waters; for although a pounder is rare, there are many of half-a-pound, and the run is not much under a quarter. But the impression produced by a Fasney trout of half-a-pound is painfully suggestive of age and ravenousness. The head is much too big in proportion to the body, the teeth are long and sharp; and you might fancy that just as constant exertion develops the muscles of the blacksmith's arm, constant indulgence of voracity had exaggerated the masticating members of these fish. But the truth is, that the trout's head seems to continue to grow when the food is too scarce to carry forward the shoulders at an equal rate, and it is by its dentation and the length of its maxillary bones that the patriarch of a pool may often be detected, rather than byits weight. A two-yearold trout of the Blackadder is probably heavier than a ten-year-old trout of the Fasney-but lay their heads together, and see the verification of the adage about old crania and young shoulders! As might be inferred from our description, the Fasney is a late stream, the spring being far advanced before the trout in it will take fly or are worth catching. But in summer it is a certain producer; and we have fished it with worm on the worst of all sorts of days for worm-fishing, when a driving mist filled the lonely glen, and the whirr of the grouse getting up from amongst the heather was like the noise of thuncler, and yet found our creel as full as we cared to carry home by the evening. Longformacus Inn, on 
the Dye, which we will have to notice afterwards, is the nearest place to the Fasney where accommodation can be had. The very head of the Whitadder is nearest to Haddington of any railway station,-from which town, however, Millknow is nine miles distant.

We could not imagine five miles of finer water than the Whitadder from the junction of the Fasney to the junction of the Dye. Gravelly streams, with here and there a rocky pool, where some aged predator lurks secure, often of no mean weight, - the gush of a little rapid occasionally, that makes eddies just adapted for fly, worm, or creeper,- - pretty bends and shallow byruns by the edge of grassy banks, into which, in the hot summer days, dozens of trout crowd to watch for food -these are the characteristics of this stretch of the Whitadder, while there are fish enough for a legion of fishers daily. Nor is their size by any means contemptible: in a flood a large average may be attained with minnow-we have known Geordie Hamilton (of whom anon) kill a three-pounder at Cranshaws, and he used to say he knew where others of even larger size had their haulds, from which he intended to abstract them the first favourable day; and a trout of a pound weight, and several of half-a-pound, may almost be relied upon by any one who fishes the water carefully with any of the other lures. We have heard that about a mile of the Whitadder near Cranshaws is supposed to be protected by the Marquis of Abercorn, but we have never experienced any interruption, although we have fished it frequently. This is the only point at which there is even the suspicion of preserving in the whole course of the Whitadder. 
Bothwell-burn joins the Whitadder at St. Agness about a mile above Cranshaws Kirk. We have only tested the lower pools, but believe that it is throughout full of trouts; and it is a capital resort in a flood.

Dye-water debouches half-a-mile above Ellemford Inn. It has run nearly as far as the Whitadder at that point-that is, about twelve miles; but its volume of water is scarcely so great, its tributaries being few and small. In its head-waters trout are excessively numerous. Above Byrecleuch-which is a curious old house, used as a shooting-box by the Duke of Roxburgh, with a farm-steading and a few cottages beside it-the number of dozens that might be taken in a day are scarcely limited save by the possibilities of casting and pulling out. In a flood with fly in April or May, baskets have been filled with surprising celerity, and scarcely anywhere will the worm-fisher find larger profits or quicker returns for his expenditure of trouble and care. Its lower parts are scarcely inferior. There are large trout in the deep and rugged pools worn out in the rock; and, just at the turn of a flood, the minnow has often done great execution. In 1856 the prize basket at the annual competition of an angling club that exists in the village of Longformacus weighed $24 \mathrm{lbs}$., captured by minnow in the part of the water that is most fished, the last three miles of its course ; while other takes were, we believe, upwards of or closely approaching $20 \mathrm{lbs}$. The principal tributary of the Dye is the Watch-water, a stream full of trout, but these of the very smallest size. We have captured dozens in it without getting one a quarter of a pound in weight. The Watch joins it a little above Long- 
formacus; while a little below it a burn of a very different character enters. Blacksmill-burn, which flows round the base of Dirrington Law, and then through some meadow-ground, yields trout of considerable size and excellent quality. Although not worth fishing for more than a couple of miles, in that space trout of nearly a pound in weight may be taken-we have even heard of one of three pounds being caught in a part of the burn little more than a foot in width. And it occurs to us here to mention a mode of burn-fishing, where there are trout of a good size, that may be practised with great success in a flood, just when the yellow colour is going off the water. Take a large-sized wormhook with a pretty long shank, tied to strong gut, and round the length of the shank beat a piece of lead such as can be drawn into the body of a minnow. Have a loop at the end of the strand of gut, and with a darningneedle pass the gut up through the minnow and out at the tail, leaving the hook projecting at one side of the mouth. The lead acts as a sinker, and the angler can work his bait in below banks and close to the bottom in a way that is impossible with the spinning minnow. Large trout take it readily; and it is advisable to give them plenty of time before striking, as they often seize the body first, and so don't get the hook into their mouth until they begin to swallow the bait. A large minnow may be used. English anglers practise fishing somewhat similar to this in clear water, with smaller bait and delicate tackle.

The pretty village of Longformacus stands on the banks of the Dye, about three miles from its junction with the Whitadder, and the neat inn at this place 
affords excellent facilities for fishing all these upland waters. From no other place indeed can the upper part of the Dye, the Watch, or the Fasney, be conveniently got at, while the Whitadder is three miles, and the higher portion of the Blackadder six miles, distant.

Half-a-mile below the confluence of the Dye, on the Whitadder, stands Ellemford Inn, the most noted of all the fishing hostels in these parts. Until within the last five or six years, its landlord was the redoubtable Geordie Hamilton, who as an angler had few equals, and as an innkeeper was beyond all praise. He died in 1856 ; but none of the fishing frequenters of the Whitadder who had the luck to visit Ellemford in the days of Geordie's glory can ever forget him. Rather more than six feet in height, with the aspect of an angling patriarch, coat and waiscoat of voluminous dimensions, corduroy knee-breeches, grey "rig-and-fur" stockings, and fishing creel of the largest size, Geordie was a sight to startle a cockney; while the heartiness of his laugh and language with those of whatever degree whom he admitted among his familiars, his shrewd border-wit, his remarkable capacity for toddy, and his wonderful fishing-stories, of themselves tempted anglers to his lonely inn on the skirts of the Lammermoors, were it but to spend a night in his company. At the waterside he was an invaluable companion. Bred as a salmon-fisher on Tweedside, he had studied the conditions of air and water as affecting angling from his boyhood; and he knew the habits and temperaments of the salmonidæ as if he had been brought up amongst themas indeed might partly be affirmed. As a minnow-fisher he was probably unequalled on the borders-as a worm- 
fisher he could only be compared with the masters. We have heard him aver that upon one occasion when he had engaged to fish Wee Willie L__ for a wager with worm, he killed in the Whitadder near Ellemford 96 lbs. of trout. At another time, when he wished to astonish some strangers who had found their way to Ellemford, he fished for a whole day in one stream above the Black Weil, between Ellemford and Abbey St. Bathan's, and when they came up to him, and saw him without his great creel on his back, they fancied he had got nothing, until Geordie pointed out thirty dozen of trout which he had thrown out in heaps upon the water-side! But even granting that Geordie could use the long-bow as well as the fishing-rod, he certainly accomplished extraordinary feats. We have seen him, when fishing with minnow just after the turn of a summer-flood, fill a basket in an hour or two almost without stirring from one spot; and it was remarked as a singular fact that, in the annual competition of the Ellem Fishing Club, (the oldest and most extensive club of the kind in the south of Scotland), the member was usually successful who had Geordie as an attendant. After reigning many years at Ellemford, Geordie quarrelled with his landlord, and flitted fifteen miles down the Whitadder to Marden; he afterwards took an inn at Reston, on the Eye water ; and finally died as host of the Cross-keys, Dunse, where we believe his spouse Jean, a Berwickshire Tibbie Shiels, still lives. We saw Geordie a few months before he died, and although greatly broken down by dropsy and rheumatic gout, his heart still panted for the water-brooks, and he speculated about future fishing-days. Helamented the degeneracy of these 
times in respect of salmon. "It's just this time forty years," he said, "that I was fishing the Kelso waitter; and atween twae o'clock on the Monday morning and sax o'clock on the Tnesday morning, we killed saxteen hundred salmon and grilse. G-d! there were as mony fish killed in the Tweed in that ae week as are killed in a hale year noo!" He was criticising the management of Ellemford Inn after he left it-for the tenant has since then been changed yearly. "They dinna ken hoo to chairge," he summed up, as the climax of their mistakes. Geordie's own tariff was according to his estimate of his guest's means: when he knew that the purse was ample, he kept a boy with a donkey flying to Dunse for the viands of the season, gave dinners at Ellemford that would not have disgraced a good Edinburgh tavern, and did not scruple to exact ample renumeration for his care and trouble. Others he satisfied with more indifferent fare, and with the most moderate charges. So throughout the season Ellemford was usually full of anglers, all satisfied with their treatment. His successors, he said, fed all alike and charged all alike; but we suspect that Geordie's absence was itself one great reason of the falling-off of customers. While on the subject, we may mention that even within the last few years we have observed a great diminution of the drinking at fishing-inns. Geordie often sat up almost the whole night over his potent toddy; and although he himself rose punctually at five o'clock, no matter how deep or late the carouse, his guests were not always able to follow his example, or indeed to fish very well after they got to the water-side. There is nothing that the angler ought more to avoid than too 
much toddy overnight. In the morning the eye is less keen, the hand less steady, the body is unfitted for prolonged exertion, the angling-animus is weakened, and the enjoyment of the sport greatly diminished. Innkeepers are often heard to complain that now-a-days the coffee-pot rather than the bottle is in requisition amongst their guests, "and if they tak ae tumbler afore gaun to their beds, they seldom tak ony mair!" -from which we infer that temperance notions have found their way even amongst anglers, and also that a new class has begun to go for recreation to unfrequented river-sides. The old roystering habits are fast changing; and (while, however, we only recommend anglers carefully to keep within the limits of their capacity-for what is more grateful than a steaming tumbler as you are looking over your pocket-book after a hard day's toil ?) -we rejoice at the reformation.

We have as yet said nothing as to the proper pabulum with which an angler ought to store his pockets; and we apprehend that that must in great measure be according to what can be had. Sandwiches are the never-failing rations out-of-doors; we have seen cold fowl and buffalo tongue exhibited with great effect by the water-side; we have fished and walked eighteen hours a-day on bread-and-cheese. Of course, portableness is the chief object to be kept in view. The meatpies sald at railway refreshment rooms are very convenient for anglers starting in the morning from a place where they are to be had. In the way of liquids, we know of nothing comparable to whisky-and-milk in equal proportions, and if a soda-water bottle-full should be judged insufficient, the angler can have his 
flask filled with the spirit, and will probably find milk at some farm-house, wherewith to renew the compound. In a hot summer-day, when he sits down to luncheon at the river-side, he ought to immerse his bottle for a few minutes in a shady part of the stream, or better, in a spring or covered runner, if it is to be had; and a cool and grateful, as well as strengthening beverage, will thus be obtained. These minute instructions are, of course, trivial, but the want of "gumption" on the part of the anglers who, usually "in populous cities pent," escape for a day or a week to the country, is often astonishing. We have met some who did not even know how to wash their hands, and had either to eat their food with fingers embrued in the blood of trouts and encrusted with the entrails of worms-impervious to any amount of rubbing with simple water -or to go without. Cold water by itself, even with soap, is ineffectual to produce cleanliness in such cases; but a handful of sand from the edge of the water, or even of mud or earth, will in a couple of minutes make them as fit for the dinner-table as if the ablution had been performed in hot-water with a cake of patent Windsor. The angler should not neglect refreshment; for although we have fished sixteen hours without eating, and experienced little stomachic inconvenience save for a little at the recurring hours for meals we are of opinion that it heightens the effect of the fatigue afterwards. Neither, if the angler intends to fish next day, should the exertion, unless for some special object, be too long kept up. Ten or twelve hours angling ought to satisfy any reasonable mortal, and allow of intervals of rest. Celebrated anglers are often distin- 
guished by great powers of endurance; but they also carefully husband their strength and energies. He who goes too eagerly to his sport in the morning, usually flags by the afternoon.

And if the angler loses the inward impulse to sport, he loses everything. There is no taskmaster standing over him, he may be careless of glory when not fishing for a wager, and, unless he is a James Baillie, his bread is not likely to depend upon his efforts. Any drooping of the spirits, therefore, caused by loss of strength or reaction from over-exertion, alters his whole view of his amusement, and he turns despondingly inn-wards just as his neighbour is getting into the full tide of excitement in the middle of a "take."

Ellemford commands the whole upper part of the Whitadder, and is still well frequented. "It was a merry place in days of old," when annual bands of Newcastle anglers, forsaking their native Tyne and the Coquet, sought the Whitadder, when their compeers of Edinburgh met them from the North, and an occasional omnibus from Berwick brought regiments from the mouth of the Tweed. But even yet, although you may haply only meet a militia captain, an India surgeon on furlough, or a wandering inspector of registers with his rod disguised as a walking-stick, and a game-bag slung under his coat instead of a creel, most pleasantly and profitably may the time be passed at Ellemford. It is six miles from Dunse, which is the terminus of a branch of the North British, and about seven miles from the Grant's-House station on the main line. The last way is ordinarily chosen; a conveyance can be had at Grant's if required, while 
by following a rough road over the hills, the pedestrian comes upon the Whitadder after four miles walking, at Abbey St. Bathan's, three miles below Ellemford, to which place he can fish up.

From the mouth of the Dye to Abbey St. Bathan's -a distance of nearly four miles-is the part of the water most fished by visitors, but it swarms with trout, some of them of large size. There are several pools in this part of the river, where, when a clear day and a low condition of the water enable one to get a glimpse into their secrets, the number of trout that may be seen is truly astonishing. With minnow or May-fly a very satisfactory average weight may be had; and the recollection of the satisfaction with which, after Geordie Hamilton had given us our first lesson in minnowfishing, we landed a trout approaching closely to $2 \mathrm{tbs}$. in Greenhope Weil, still remains after many days. A few sea-trout find their way up so far by every flood after the middle of June, and, when they are in the water, the Black Weil and Greenhope are sure to have their share, so that a cast for them in those places with a special lure-a whitling or very small grilsefly-is sometimes worth trying. They are often, however, taken by the trout-fisher with fly or worm. The last tenant of Ellemford Inn used to capture them, after the water had got so clear as to let him know their " haulds," by working three large hooks, tied together, back to back, and leaded so as to sink them under the fish, and by a sudden jerk hooking it by the body-when of course it made great play. Monnynut-burn comes in a little above Abbey St. Bathan's, and contains considerable store of trout. 
The angler should always betake himself to such small waters when he finds the larger stream yielding him sport relucantly.

Abbey St. Bathan's is a pretty little village, an oasis amongst the desert Lammermoors, deriving its name from an ancient conventual establishment dedicated to St. Bothan. It is, as we have said, four miles from the Grant's-House station of the North British railway. Formerly Mattie Pringle's rude little hostelry there used almost to rival Ellemford, having been indeed, we believe, of older date; but when she died, her daughter Maggie scarcely kept up the character of the house, and finally ran off with a soldier or a navvy-(how the ways of men and women are the same in the lonely village amongst the hills as in the seething factory-town!)-and the licence was withdrawn. It is now, however, again under respectable management-there is a cleanly double-bedded room -and as to the licence, why, 'tis not far to Dunse. The most picturesque part of the Whitadder is the stretch of four miles below the Abbey. The rugged banks are finely wooded, and at the Copper-mines (that metal having been anciently wrought here), the water labours through a rocky channel-in one part so contracted that it may almost be stepped over, in another boiling out into a "Devil's Cauldron," popularly deemed unfathomable-as if the stream born of the hills were making great efforts to break through the iron barrier that prevented its descent into the plain below. The angling in this portion of the water is admirable, and in the deep eddying pools there are trout of the largest dimensions. At last, winding round 
the base of Cockburn-Law, the Whitadder leaves the Lammermoors for the rich low-lying Merse. It is here most readily got at from Dunse, which is two miles distant from the Whitadder. (On Dunse-Law, under which this douce little town is built, General Lesly, afterwards Earl of Leven, twice encamped with a large army of Covenanters, - the first time dictating terms to King Charles I., who lay with his forces at Berwick, the second time making his way by Newcastle into Yorkshire, where he concluded a favourable treaty. The remains of the godly camp on Dunse-law are still pointed out.*) Dunse has two excellent inns ; and the Cross-Keys, kept by Geordie Hamilton's widow although a second-rate one, might do for many an angler.

From Preston Bridge, the nearest point to Dunse, down to Chirnside, the Whitadder is a good deal fished, chiefly by local anglers; but that it has abundance of trout will be demonstrated to any one who happens to

* "Lesly's March," a ditty that records these triumphant performances of the Scotch Presbyterians, under their able Generals, the two Leslies, has, considering its origin, remarkably little of the savour of grace in it. Indeed it begins,

\section{"March! March !}

Why the devil do you na march?"

and while it professes the object of the marching to be "true gospel to maintain," it has the following naive declaration of national conceit :-

"When to the Kirk we come,

We'll purge it ilka room, Frae popish relies and a' sic innovation.

That a' the warld may see,

There's nane in the right but we

Of the auld Scottish nation."

Yet Professor Blackie thinks it his mission to teach his conntrymen to estimate themselves a little more highly than they do ! 
be on its banks in April or May, when a "take" comes on. The tront, for the rest of the Whitadder, below this point, are on the whole larger than in the upper portions; and fly-fishing may be practised a week or two earlier in the season. It is equally adapted for all kinds of angling. At Chirnside, which is a station on the Dunse branch from the North British, there is a comfortable village inn. A paper-mill here, however, spoils the fishing somewhat for a couple of miles, and the angler following the river need not grudge an hour or two to take a peep at Ninewells, the birthplace of David Hume, and where he sometimes stayed after he had acquired fame. (Some of his comical hoaxes and jeux d'esprit, addressed to his friends in London-all the more comical as coming from such a philosopher-are dated from Ninewells. He was one of the Berwickshire Homes, but altered his name to make it accord with the border pronunciation, for with Mersemen of all degrees the Earl of Home is the Earl of Hume.) It is not until it reaches Allanton Bridge that the Whitadder reacquires its character. Here it is joined by the Blackadder. Allanton has an inn, or respectable public-house ; but it has changed its occupants since, sleeping there on one occasion, we were astonished in the morning by a charge of eighteenpence, the payment of which was in full of all demands for bed, breakfast-a Scotch breakfast-and a glass of toddy. "She didna chairge onything for the bed," the hostess said, and could with difficulty be prevailed upon to accept half-a-crown. We fear that the old body is dead. 
Springing from the breast of Twinlaw-Cairns, the Blackadder is at first a heather-burn, with most ancient and hardly fish-like inhabitants. Once, when tracing it to its source, our last cast, where the infant stream, two feet broad, makes its way down the hill-side, produced an animal so black and grim-looking, albeit a quarter of a pound in weight, that we bolted incontinently over the shoulder of the hill to the head of the Watch-water, where the trout, although pigmies, have bright yellow sides and starry backs. After it gets to the foot of the hill, and flows through the upland meadows, the farmers have made most lamentable intromissions with its windings for several miles both above and below Wadderlee-have straightened its course, destroyed the well-worn banks in which trout harbour, and given it a bed of clay, for such guests unmeet. We caught a stalwart Merseman in flagrante delicto, "sheughing" a new run for the juvenile Blackadder; and but that he gave us the legend of the Twinlaw. Cairns-a black hill with two pyramidal piles of stone on the top of it-we should not have passed him by without a left-handed blessing. We cannot retail the particulars of his story; and indeed it smelt, we opined, a good deal of Mackay Wilson; but it was to the effect that in some foray from the Merse into England, an infant was brought away, and reared by a family of the Humes; and that, when he had grown to be a man, his name and lineage remaining unknown, a " return match" came off, an English army having found its way to the head of the Blackadder; the nameless youth stepped forward and challenged any of the Southron host to single combat; an opponent came out to meet 
him-they fought-and both fell; when it was discovered that each had slain his twin brother; whereupon the Cairns were erected to commemorate the fratricidal catastrophe, and hence the name of the hill or law. But while miles of water are spoiled by the straightening of the water-course, there are occasional places where trout still remain. From a hole below Wadderlee, left somehow, or wrought out somehow, in the straight bed that had been cut, we once took a trout considerably more than a pound in weight, and never did fish fight more gallantly for his life. Except for curiosity, however, the Blackadder is not worth following above its junction with a water about its equal in size, that comes in from the direction of Westruther, of the angling capabilities of which we cannot speak. It is here, indeed, that the stream begins to assume its peculiar character, and that long sluggish pools terminate and give rise to short lively streams, into which large trout move at feeding-time. There is no long rippling channelly flow of water in the Blackadder, there being more slow pools than fast streams. In these pools, save when fly-fishing with a wind, or minnow-fishing after a flood, it is of no use to angle; so attention should be chiefly directed to the runs and occasional by-places. The district is lonely: with the exception of a single farm-house and a herd's cottage or two, for five or six miles above Greenlaw there is no sign of human life. But if the fishing life is not so exuberant as in the Whitadder and its other tributaries, the size of the trout makes ample amends. No water, however, requires greater care on the part of the angler. Small flies and the very finest tackle, or 
red and lively worms, and much creeping and caution, are necessary to tempt fish the abundance and excellence of whose ordinary feeding is manifested in the pinkness and firmness of their flesh when cooked. The Fangrist-burn, which flows in from Dogden-moss, has much of the character of the Blackadder itself, but of its inhabitants we are hardly entitled to speak from one unsuccessful trial.

Greenlaw is the county-town of Berwickshire, and is eight miles from Dunse and ten from Coldstream, without any public conveyance running from either of these places. It is, therefore, out of the way, and is scarcely a resort of angling tourists; but it is nevertheless well worth a visit, as from it only can the head of the Blackadder be conveniently fished. It has a large and commodions inn.

For two or three miles below Greenlaw, the angling in the Blackadder is open to the public; but for the rest of its course it is almost all carefully preserved by the different proprietors through whose land it flows,Sir Hugh Campbell of Marchmount, Mr. Swinton of Kimmerghame, Mr. D. M. Home of Wedderburn (who even tries to preserve the Tweed at Milnegraden and Paxton!) Mr. Buchan of Kelloe, Sir George Boswell of Blackadder, and others. By some of these, howeverchiefly by Professor Swinton, younger of Kimmerghame -leave is, we understand, prettily liberally given, and a visitor at Dunse might probably find little difficulty in obtaining permission to have a day in the lower parts of the Blackadder, where the trout are even bigger and better than in the upper waters. Geordie 
Hamilton used to talk, more suo, about "trailin' them oot wi' the mennon, twae-punders and three-punders." We are not distinctly informed as to some small portions of the water in which the angling is not restricted, and hesitate to recommend anglers to go on chance to a stream where the cordon of gamekeepers is scarcely if at all broken. This protectionist system is quite of recent date.

From Allanton, where the Blackadder joins, the Whitadder's course to the Tweed is about nine miles in length. It receives no other tributary of any note, not even a burn that is worth investigating. From Allanton-bridge, to Hutton-bridge, a distance of about five miles, a day's fishing of the very best description may be had. At the Bluestane-ford there is a stream famous amongst the anglers of the district, and every two or three miles there is a deep mill-dam where large trout are bred, and which is a sort of reservoir for the supply of the streams above it. The trout are of good average size, and still numerous, although not to be compared to the swarming populations of the upper streams. Such continues the character of the Whitadder to its month. Although for the final two or three miles of its course it is very much fished by the anglers of Berwick and of neighbouring villages, there are still trout enough for all, and, even within the last fer years, very great takes have been got. We have known of one or two trout upwards of three pounds in weight being taken from the Whitadder; but of course even pound fish are exceptional, although the chance of one or two is almost always offered to the expert angler. We have captured an eel upwards of 
$2 \mathrm{Hbs}$. and another about $4 \mathrm{bbs}$. in the lower part of the Whitadder.

Of late years a considerable nuisance and obstruction to angling has arisen in the Whitadder. The Anacharis Alsinastrum, the weed that has almost choked up the canals of Lincolnshire and others of the midland English counties, first made its appearacce in this kinglom in Dunse Castle loch, where it was discovered about seventeen year's ago by the late Dr. George Johnston of Berwick (who was a keen angler as well as an eminent naturalist.) The intruder found its way into the Whitadder, and has established itself in most of the mill-dams, threatening almost to block them up. It seems not to be particular about what sort of root it gets, but spreads with amazing rapidity, until in several places it has almost stretched across the Whitadder. A sprig of it put into a tumbler of water will indeed in a very short time fill the vessel without taking any root at all. Large trout hooked in the neighbourhood of a bed of this weed make a dash into it, and if the angler is fishing with fly, he may be thankful if he recovers his cast, without much regretting the certain loss of the trout. Fortunately the recurring floods help to repress its extension, and it cannot obtain a footing in the streams. In no other Scotch river that we know of has this annoying invader presented itself.

It is stated that, some thirty or forty years ago, salmon freely entered the Whitadder; but singularly enough, considering how many must pass its mouth, scarcely a specimen of the grown salar ever ventures into it now. Even in the most plentiful seasons, very 
few grilse visit it either. Hosts of bull-trouts, however, swarm into it in the spawning-time, and a favourable flood spreads them throughout its waters, almost to its source. A pretty high cauld about a mile from its mouth prevents their getting up if the flood is only a low one, and thus in the dam at Cantie's Bridge many hundreds of them are kept throughout the winter. In the old kelt-killing days, when the occupier of the public-house at the bridge leased the fishing in this pool, murderous slaughter used to be committed in it every spring; but of late years it has been preserved, and the abortive experiments to ascertain the rate of the kelt's growth have been made here.

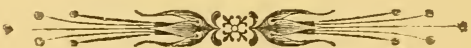




\section{CHAPTER VIII.}

THE EYE, THE TYNE, AND THE ESKS.

6 HE pedestrian angler passing from Grant's House to the Whitadder is sorely tempted by a burn with some pretty pools and runs that he has to cross; and indeed most people put up' their rods and take a cast. This is the Eye-water. It rises amongst the hills behind Abbey St. Bathan's, but almost from its source flows through upland meadows that are rich enough to provide feeding equal to that of most waters that flow at a lower altitude. The trout are both numerous and of good size, and if there has been a flood the night before, the angler bound for the Whitadder cannot do better than devote his forenoon to it, either immediately above Grant's, or above the point-where the road to the Abbey crosses it. Half-a-mile or so above Grant's (the Eye flows within a few hundred yards of the railway station) there is a part of the water that seems to have been straightened or cut at some time; above that it runs in a very narrow bed, down which the angler can follow his worm without being seen; farther up there are pools and good holes. Between Grant's House and Reston, the next station on the North British, the fly-fisher is greatly interrupted by trees-(we once lost almost a whole day by persisting in trying to fish with fly from Reston upwards.) There is, however, 
a mile of water nearly clear from wood below Grant's, -but a General Somebody, who rents a house in the neighbourhood, has set up a claim to preserve part of it. It is less than a quarter of a mile in extent, and is not a very choice piece of water; so before the hulking ploughman who acts the gamekeeper can get down to the trespasser, he will probably have pretty well ransacked the General's treasures, and can either make an apology or not, as he thinks proper, before walking off. The worm, used with a short line, and dropt into the streams from behind trees, is, however, effective in the Eye; and in a flood, we should think a basket-full of very good trout might be got with the dipping-minnow, which we have already described(see the Dye, in Chapter VII.) - and which could be wrought under the tree-roots, where the large fish lie on the look-out. There are some bleaching-mills or other works a little above Reston, which spoil the Eye in the immediate neighbourhood of that village; but a little farther down it in great measure recovers itself. There is still, in the four miles between Reston and Ayton, a good deal of interruption to angling caused by wood; but much of it is open, and may be fished profitably with fly. The worm, however, is the most effective lure, the stream running favourably for its use. There is also a paper-mill at Ayton, which has anything but a beneficial effect upon the angling. Below that little town, the Eye flows through the grounds of Ayton Castle, and is probably preserved, although we have fished it without interruption, but so early in the morning that perhaps the gamekeeper had not got up. There are capital trout in this part 
of the water. These grounds, however, extend to within a mile or so of the mouth of the Eye, and it would not be worth any one's while to miss the preserved water in order to fish what is left, if indeed that is not preserved also. This little Berwickshire river enters the sea at the fishing-village of Eyemouth.

At Grant's House, Reston, and Ayton, all needful accommodation may be obtained; and these stations are so conveniently situated, that there is just a quiet day's fishing, between the morning and the evening evening trains, from one to another.

The Haddingtonshire Tyne is noted for the size and quality of its tronts, for the strictness with which it is preserved, and for a highly unsatisfactory decision in law which has given a colouring of legality to the exclusion of the public from angling in it." Its sources are on the verge of the vale of Gala- the Tyne and its principal tributary, Cakemuir-water, rising close to each other, although scparating widely before they meet again near Saltoun House. So rigidly is the exclusion of the public enforced, that it is almost an aqua incognita to modern anglers who do not possess the privilege of acquaintanceship with any of the proprietors of its banks. The Tynehead station, on the Edinburgh and Hawick line, receives the angler near its source, and we believe that for a few miles, while it is but a burn, no restriction is attempted. At that part, however, it is not of so much value as a trouting stream, although it has already acquired the peculiar character that distinguishes it throughout its course. There are, however, a good many trouts, and it is much frequented by anglers who are acquainted with it. Gorebridge 
station also suits for catching it a little further down at Crichton by a walk of a couple of miles. From Tynehead station Cakemuir-water may be reached.

. In the neighbourhood of Haddington a mile or two of the Tyne may be fished by the public, and the trout are of large size; but of course there is too much local fishing to allow of great temptation to the roving angler. From thence to Tyningham, the river is literally shut up, and the utmost pains are taken to exclude unprivileged rods. Until lately, fishing used to be allowed from Linton up to near Hailes Castle; but that too has been stopped, and we believe some of the lower parts are rented for trout-fishing-a thing entirely unparalleled in the south of Scotland. We have heard that a newly formed angling-club in Edinburgh has a vague notion of leasing a part of the Tyne; but we trust that its members will think better of it, and offer no premium to the churls who, if they do not greedily reserve to themselves a sport that so salutarily might be free to all, at least play the miserable parts of dogs in mangers. Landed proprietors who can act so may be supposed to be actuated by very mean motives, and we have no doubt would eagerly let their waters; but certainly angling clubs ought to be the last of all to give them any encouragement.

There is much of baronial magnificence and tradition in the vale of the Tyne. At its very source stands Crichton Castle :-

"That Castle rises on the stcep

Of the green vale of Tyne;

And, far beneath, where slow they creep,

From pool to eddy, dark and deep,

Where alders moist and willows weep,

You hear her vale repine. 
Crichton ! though now thy miry court

But pens the lazy steer and sheep,

Thy turrets rude and tottered keep

Have been the minstrel's loved resort."

Winton, Salton, Lethington, Hailes Castle-the hold of the Hepburns-and Tyningham, the seat of the Earl of Haddington, speak of the richness of the valley through which the Tyne flows.

Pressmennan-loch, within reach of Linton station, is well stocked with trout, of the celebrated Lochleven breed, we believe; and while the late Mrs. Ferguson of Biel was alive, permission to angle it was pretty freely granted. Her heir is Mr. R. Dundas Christopher Hamilton-Nisbet, who we hope is equally liberal. The Burn of Biel, which flows partly throngh the same estate, and partly through that of Mr. Balfour of Whittinghame, is also said to be populous with good trout.

While the Tyne is thus almost blotted out from the Scottish Angler's map by encroachments upon ancient rights, other causes have conduced to render both the Esks equally unknown to him, and something very different from trouting-streams. The North Esk is a mere factory drain; and though the South Esk is not so much polluted, and contains some trouts, it is carefully shut up from the public. At the meeting of the Commissioners of Supply for the county of Edinburgh in January 1858, we find the newspapers reporting the following discussion:-

"The Duke of Buccleuch, in reference to the statement in Mr. List's report as to the sanitary condition of the villages, said the state of the rivers, and more especially the North Esk, was rapidly becoming a very serious and was already a very 
grievous evil. At present, the North Esk was so polluted that the water could no longer be used for drinking purposes, nor indeed for any household purpose whatever. It was not even fit for cattle and horses, and in Dalkeith Park he had had to erect fences along the stream to keep them from drinking of it. The effect on the fish was such that, while up to within a few years they had abundance of salmon trout in it, these had almost entirely disappeared, though formerly the trout there were some of the finest in the south of Scotland; and, even when they were caught, dressed, and put upon the table, the smell they emitted had been such that they had had to be sent out of the room. On the South Esk there was only one factory, but on the North Esk the bleaching works and other factories were very numerous. He did not know whether the evil was altogether due to them, but he had no doubt it was so in a large measure, and he trusted that these factories would do as those at Hawick, Selkirk, and Galashiels had done, where, under the pressure of the Tweed Commissioners, they had made arrangements by which the water was so filtered that the poisonous ingredients were prevented getting into the river.

"Viscount Melville said that he also was one of the sufferers from this grievance. There could be no doubt that deleterious liquids were allowed to find their way from these factories into the stream; this was shown by the whitefoam that came down daily from the mills at Lasswade; and at one mill opposite to Mavisbank he thought the nuisance perfectly unjustifiable. The mischief that these mills had created was past all belief, and he hoped that something would be done to remedy the evil.

"Mr. C. Cowan said that, from the extent to which manufacturing had increased upon the banks of the North Esk, they could scarcely expect that the stream should be as pellucid as it was in the days of their forefathers. He wished, however, to state, for his partners and himself, that they had adopted and continued to enforce, as much as possible, every means for reducing the evil to its lowest possible amount; and he believed it was the general wish of all his brethren in the trade, from Penicuick to Dalkeith, to do everything in their power for that purpose. They must bear in mind, however, that papermaking 
was not the only cause of the evil now complained of. There were coal-wastes along the stream, the refuse from which he believed to be most destruetive to animal life. Gas-tar was also another pernicious ingredient that found its way into the stream. In addition to that, they had found a practice prevailing of stealing chloride of lime from their works for the purpose of destroying fish-a practice which it was by no means easy to ensure them against. He did not deny that there was ground of complaint, but he was afraid that much of it was inseparable from the growth of manufactures and the extent to which they were carried on. He believed, however, that the construction of reservoirs for storing water for the summer season would tend in a considerable degree to meet the evil.

" Mr. Scott Monerieff said that ever since he knew the river it had been the recptacle of the sewage of the little towns on its bank; but it was only of late that poisonous ingredients had flowed into it from the paper factories. There used to be abundance of trout in both rivers; now there were none. There was a great change for the worse, which he could not attribute to anything but the extension of the paper works, and he could not but think that through the exertions of the proprietors of these mills the nuisance might be diminished.

"Sir W. Gibson-Craig thought the question was not purely a local one, because it referred to all the rivers in the county, including the Water of Leith. He thought it a matter of public interest, and one which, as a County, they ought to take up.

"The Duke of Buccleuch said he also looked on this not as a local, and still less as a personal question. It was a matter of serious inconvenience to a large body of the people that the water should have become so unfit for use; it was a matter that affected their personal health and comfort.

" On the motion of Sir IV. Johnston, the subject was remitted to the General Committee."

This is a miserable condition for a classic stream like the Esk to be reduced to; and these facts are sufficient of themselves to suggest the necessity for the authorities to use every vigilance and precaution to prevent 
any of the border-streams that yield tribute to the Tweed from being similarly spoiled. No exertion ought to be spared to enforce such preventives as will keep the Teviot from becoming a huge and offensive ditch. Cost and care, so long as they do not actually become incompatible with the existence of the factories, ought to be no element in the question of keeping our border waters pure and sweet.

The upper waters of the Esks, however, above the mills, have still abundance of trout. The sources of South Esk are in the Moorfoot Hills; and Gladhousewater, Moorfoot-burn, and Borthwick-burn, have all pools containing numbers of trout (not of large size), and may be fished successfully after a flood. They are all attainable from Gorebridge, Fushie-bridge, or 'Tynehead station. They lie high, however, and the trout are late in getting into condition. We do not know precisely at what point the protection of the Esk begins - probably it is in the neighbourhood of Arniston.

The North Esk comes from the Pentlands. The true source of the stream is above Carlops, towards which place it flows from the hills straight south, and then bends suddenly to the north-east by Penicuick. It is perhaps hardly worth while to begin fishing below the Powder-mills, about two miles above Penicuick; but either in the Esk or in the Nine-mile Burn, above that point, quantities of small trout may be taken, especially in a flood. The only tributary of any note received by the North Esk is Logan-house-water or Glencorse-burn, which crosses the roads about six miles from Edinburgh. In the neighbourhood of Glencorse it is probably preserved, and we remember to 
have fished it from the Biggar-road up to the Compensation-pond with an impression on our mind that we were dabbling among stolen waters,-whether derived from having read some threatening placard, or from the prima facie notion of trespass suggested by climbing over a wall, we cannot now say. It is a pretty burn, with nice little pools. The reservoir, which is fully a mile in length, belongs to the Edinburgh Water Company, who do not permit "permiscuous" fishing in it; and the men who look after it and the more recentlyformed one farther up the glen have, we believe, instructions to put queries to any angler about his right to fish. The run of the water between the two reservoirs is not, however, preserved, and we have managed to pick out a few trout from it with worm. After a flood, we should imagine numbers of fish would ascend from the lower pond into the burn. There are large trout in the reservoirs, and we have heard of an average of a pound being attained in it with fly. No one need go to Loganhouse-water for solitude. Probably he has just got his rod put up, when half-a-dozen of long carts, full of people, with flags flying and a couple of fiddles or a pair of bagpipes playing, assail at once his eye and his ear. A cab or two may also whirl past. For the road up the glen leads to Habbie's Howe, where the canny citizens of Edinburgh love to pic-nic. In all likelihood, a few carts-full will establish themselves half-way up on the edge of the water; the grown-up folks will commence dancing to the aforesaid musical instruments within sight of the trouts that have already been horrified by the procession along the banks, and the juveniles of the party will 
amuse themselves by rushing up and down the burn throwing stones into it. What Job-supposing him to have been an angler, as is highly probable from his character-would have done under such circumstances we cannot say; but the angler who has not leave to fish in the ponds must make "up his mind to amuse himself for the day in some other way than by angling. There are no trout in the little burn that comes down from the reputed Habbie's Howe, and feeds the upper pond. It is, however, a beautiful spot. The green Pentlands rise sheer up on each side; the glen narrows to a piss; the streamlet drops from one side of the hill, forming tiny cascades; and if the angler climbs up by the linns, he will see below each fall a clear rocky pool, of considerable depíh, but apparently without a single fishy inhabitant. We have thrown in a worm in vain, and turned over the stones fruitlesslyso have come to the conclusion that these pools are tenantless, and probably have always been so. There is not, however, any such tempting place for lasses to bathe in as is described in Allan Ramsay's beautiful pastoral. This must be sought for at New Hall, five or six miles farther on the road to Dumfries.

At the very mouth of the Esk, notwithstanding the Duke of Buccleuch's statement, sea-trout are still to be taken. On a Saturday afternoon in April 1857, when the river was actually opaque from the stuffs let off from the mills at Lasswade and other places (which are cleared weekly), we caught a pretty fish, upwards of a pound in weight, while experimenting with a very small grilse-fly, and raised another. We believe one or two are to be had almost every day of 
the year; and certainly, when dressed and put upon the table, they do not emit such a smell as to require them to be sent out of the room.

The banks of the Esks, however, will continue to be frequented, even although every specimen of the salmonidæ in them should be utterly clestroyed. From Habbie's Howe to Musselburgh, almost every step is interesting.

"Sweet are the paths, oh? passing sweet,

By Esk's fair stream that run

O'er airy steep, through woodland deep,

Impervious to the sun.

From that fair dome where suit is paid, By blast of bugle free,

To Auchindinny's hazel shade,

And haunted Woodhouselee.

Who knows not Melville's beechy grove,

And Roslin's rocky glen,

Dalkeith, which all the virtues love

And classic Haw thornden?"

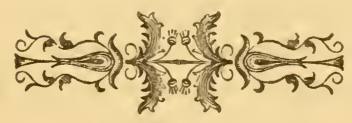




\section{CONCLUSION.}

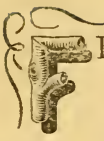

ISHING is a kind of hunting by water, be it with nets, weeles, baits, angling, or otherwise, and yields all out as much pleasure to some men as dogs or hawks. "When they draw their fish upon the bank," saith Nic. Henselius Silesiographiæ, cap. 3, speaking of that extraordinary delight his countrymen took in fishing and making of pools. James Dubravius, that Moravian, in his book de pisc. telleth how, travelling by the wayside in Silesia, he found a nobleman, "booted up to the groins," wading himself, pulling the nets, and labouring as much as any fisherman of them all : and when some belike objected to him the baseness of his office, he excused himself, "that if other men might hunt hares, why should not he hunt carps?" Many gentlemen in like sort with us will wade up to the arm-holes upon such occasions, and voluntarily undertake that to satisfy their pleasure, which a poor man for a good stipend would scarce be hired to undergo. Plutarch, in his book de soler. animal. sueaks against all fishing, "as a filthy, base, illiberal employment, having neither wit nor perspicacity in it, nor worth the labour." But he that shall consider the variety of baits for all seasons, and pretty devices which our anglers have invented, peculiar lines, false flies, several sleights, \&c., will say that it deserves like commendation, requires 
as much study and perspicacity as the rest, and is to be preferred before many of them. Because hawking and hunting are very laborious, much riding and many dangers accompany them; but this is still and quiet: and if so be the angler catch no fish, yet he hath a wholesome walk to the brookside, pleasant shade by the sweet silver streams, he hath good air, and sweet smells of fine fresh meadow flowers, he hears the melodious harmony of birds, he sees the swans, herons, ducks, water-horns, coots, \&c., and many other fowl, with their brood, which he thinketh better than the noise of hounds, or blast of horns, and all the sport that they can make.

Be not dismayed, long-suffering reader, by our unexpected erudition, and the sudden gravity of the style of this little book. These words were written nigh two hundred and fifty years ago by Robert Burton, the Anatomist of Melancholy, and in his remarkable work, part 2, sec. 2, mem. 4, you may find them for yourself. They comprise the philosophy of our sport, and prettily point out, in the general, the attendant pleasures of its practice, which in the particular, as regards the streams of these Border counties, we have feebly endeavoured to expound. "If so be the angler catch no fish,"-which may unluckily happen to the best of our craft-Nature is at hand to minister to him consolation; and history, tradition, and song,the mouldering tower or abbey, the battle-field, and the broomy knowe-by their associations compensate him for disappointment. Without weakening our admonitions to diligence in his calling, we may yet recommend the angler to keep his eyes and his ears open 
by our river-sides. We never grudge a few minntes to look for the nest of the sand-piper or the waterowzel-to have a helter-skelter chase down the stream after a brace of flappers which with a despairing quack finally run their heads into some hole or bush, whence they may be drawn-or even to watch the sly waterrat as he swims boldly across the pool, and then catching a sudden glimpse of the onlooker dives like lightning, and may be seen rumning along the bottom to his hole. The angler, it is true, to be successful must resume as far as possible original instincts, constant alertness, vigilance of eye, readiness of hand, craft and cunning. If a man, with his fly in the water, is dreaming about a mathematical problem or the last change of government, it is a second or so before he recalls his thoughts sufficiently to remember that that tug at his line ought to have been the signal for instant striking; he raises his rod clumsily and in a hurry, but the fish is gone. When he is fishing, therefore, let nothing divert him from it, and let him work as "a poor man for a gool stipend," with his master superintending him. But lay down the rod occasionally and look about you; " mingle with the universe" as well as you may, and take your pleasure out of this beautiful earth as your capacity enables you. Remember the reverent hearts with which the old anglers went to their recreation; and read sometimes the memorable conversation of the father of your craft with his pupil, - the best of all sermons on the text "the meek shall inherit the earth"- which terminated within sight of Tottenham High-Cross :- "And this, and most other blessings, we enjoy daily. And for most of them, be- 
cause they be so common, most men forget to pay their praises; but let not us, because it is a sacrifice so pleasing to Him that made that sun and us, and still protects us, and gives us flowers and showers, and stomachs and meat, AND CONTENT AND LEISURE TO GO A-Fishing."

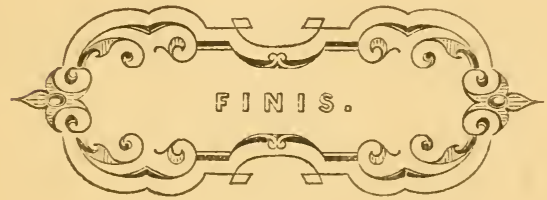





\section{A $\mathbb{A}$ G'S.}

\section{THEANGLERS, E M P ORIUM}

AND

GREAT SPORTING IMPLEMENT ESTABLISHMENT FOR FLOOD AND FIELD,

5 HANOVER STREET, EDINBURGH.

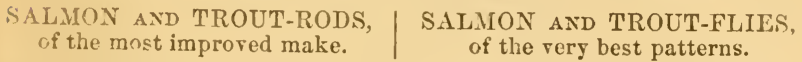

REEL LINES of all kinds.-REELS of WVOD, BRASS, and SILvER.

LANDING-NETS, FISH-BAGS and BASKETS.

V $\mathbb{E} \mathbb{R} \mathbf{F I E}$ GUT,

and Strong Salmon Gut in the Hank.

The above are highly recommended to Sportsmen, being all manufactured on the Premises, of the best-seasoned inaterials.

PREPARED BAITS.

CRICKETING IMPLEMENTS,-BATS, Balls, \&c. \&c.

GOLFING IMPLEMENTS,-CLUBS, BALLS, \&c. \&c.

\section{TO SPORTSMEN.}

\section{J. E. II O G G,}

(ESTABLISHED IN 1837)

9 PRINCE'S STREET, EDINBURGH, OPPOSITE THE MOUND,

Has alwaỵs on hand

A LARGE ASSORTMENT OF SALMON AND TROUT FLIES, FISHING-RODS, REELS AND LINES, \&c., \&c., F O R A L L R I V E R S

In Scotland, England, and Ireland, and for Exportation.

SAINON AND TROUT FLIES, FISHING-RODS, REELS AND LINES, AND TACKLE OF ALL KINDS,

MADE TO ORDER in the most approved manner.

Foreign and CoUntry ORders | Repairs Carefully Exectted Promptly attended to. on the Shortest Notice. 


\section{Hurrah for Old Scotia's Streams! \\ TO THE LOVERS OF THE GENTLE ART.}

ALL ANGLERS WOULD DO WELL TO VISIT

\section{A. \& G. WILSON'S FISHING-TACKLE STORE,}

And supply themsel res with one of their

LANCES or SPEARS, from 14 to 16 feet long,

Which are articles not to be equalled in the Three Kingdoms for MATERIAL,

WorkMANSHIP, and DURABILITY; Alid also their

A R T I F I I A L B A I T S,

Acknowledged by thousands for their killing qualities to surpass anything

ever invented,-even killing two to one agraiust the Natural Bait.

Gentlemen are respectfully invited to inspect their Stock on hand, comprising ever'y article requisite for the Angler.

A. \& G. W.'s long experience in the line enables them to give every infor-

mation to Gentlemen proceeding to the various Fishing Stations.

Portable Fisming Boats from $£ 9$ to $£ 20$.

$$
\text { Please to observe, - }
$$

THE OLDEST FISHING ESTABLISHMENT IN EDINBURGH,

A. \& G. IV I L S O N,

FISHING-ROD AND TACKLE MAKERS

To H. R. II. Prince Albert,

34 PRINCE'S STRET,

Opposite the North British Railway Station.

TO PLEASURE-EXCURSIONISTS.

THE

\section{NORTH BRITISH RAILWAY HANDBOOKS,}

DESCRIBING

THE SCENERY AND REMARKABLE PLACES

ON THE LINE,

May be obtained at the Principal stations.

I. THE TRIP TO DIRLETON AND NORTI BERWICK, including also Dirleton Castle and Gardens, the Bass, Tantallan, \&c. Price2d.

II. The TRIP to COCKBURNSPATH, with a Visit to Dunglass DEAN, Pease Bridge, Fast Castle, Coldingham Priory, \&c. Price 3 d.

III. THE Route To BERIVICK-UPON-TWEED, by the Battle-fields of Pinkie, Prestonpans, Dunbar, \&c., with a description of Berwick, its Ramparts and Royal Border Bbidge, the Tweed, \&c. Price 3d.

IV. The TRIP to JEDBURGH, describing also BorTH WICK and CRICHTON Castles, Abbotsford, Melrose, Dryburgh, Kelso, \&c. Price 3d.

Printed and Published by Robert Hardie \& Co. 77 Rose Street, Edinburgh. 


\section{Just published, price 5s., cloth,

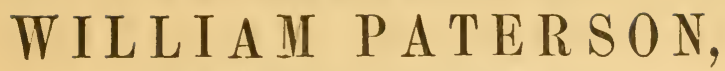

THE MERCHANT STATESMAN, AND FOUNDER OF THE BANK OF ENGLAND.

BY S. BANNISTER, M. A.

Formerly Attorney-General of New South Wales.

\section{OPINIONS OF TFI PRESS.}

"The Life of Paterson is an interesting episode in the history of his age."-Athenæum.

"William Paterson was among the wisest men of his age, and this biography is a fitting memorial of his patriotism and genius.

This Biography, intriusically valuable and interesting to all classes, is peculiarly welcome as a book for the instruction and encouragement of the young."-The Leader.

"William Paterson was evidently a man of great enterprise, originality, firmness, and sense; his career was full of strange vicissitudes; he powerfully affected the fortunes of Scotland during a quarter of a century; he was brought into contact with the most eminent men of his day."-Saturday Review.

"However acquired, Paterson possessed considerable knowledge, both of history and of the principles of trade and currency of a sound kind. .... It is only within these few years that his liberal free-trade notions have been reduced to practice, if they are now. ..... On a more difficult, because a less palpable subject than free trade, namely, currency, Paterson's ideas were not only in advance of many theorists of his age, but of ours also."-Spectator.

"William Paterson, driven by religious persecution from his native land, at an early age zealously took to mercantile matters, and became opulent at the IV est Indies. He then settled in London. Jesides founding the Bank of England, he originated the ill-managed Darien Colony; constructed the Sinking Fund of 1717 ; started a Company, still in existence, to supply the north of London with water from the Hampstead Hills; and wrote several admirable letters upon trade and finance."Morning Post.

"Mr. Bannister's Life of Paterson is, on the whole, to be commended for the pains spent on its execution. It is a valuable little book."-The Examiner.

"Now that commercial integrity is at a very low ebb, the young and aspiring merchant may study with advantage the life and conduct of such men as William Paterson, who, amidst the struggles and adversities of a laborious career, maintained his honour and integrity of character to the last."-Monetary Times and Bankers' Circular.

Edinburgh : WILLIAM P. NIMMIO, 2 South St David Street.

London: W. Kent \& Co., Paternoster Row.

And all Booksellers. 


\section{LEGIBLE RAILWAY REDING.}

L A T E L Y P U B IS H E D, Price 1s. each, in Fancy Covers,

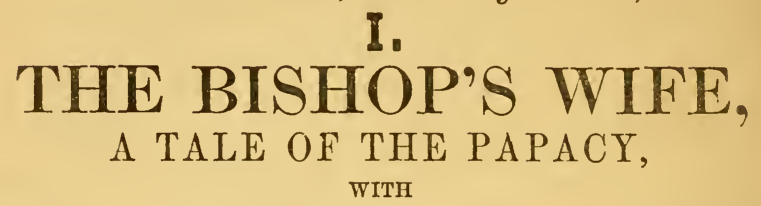

A HISTORICAL NOTICE OF

THE LIFE AND TIMES OF HILDEBRAND, (POPE GREGORY VII.)

TO WHICII IT RELATES.

By Mrs. G. R. STODART, Edinburgh.

The Scotsman says of this Work-"The Bishop's Wife describes one of the most cruel and memorable of the misdeeds of Popery-the unmarrying of the German Clergy by Hildebrand in the 11th century. It has stirring and even thrilling incidents."

\section{II.}

THE HISTORY OF THE PONTIFICATE OF

PIUS THE NINTH,

INCLUDING A NARRATIVE OF

THE POLITICAL MOVEMENTS IN ITALY

IN 1846 TO 1850,

\section{AND AN ACCOUNT OF THE}

SIEGE OF ROME BY THE FRENCH, BY AN EYE-WIT NESS,

G. B. NICOLINI,

OFFICER OF THE GENERAL STAFF OF THE ROMAN ARMY.

W. P. NIMMO, 2 SOUTH ST.DAVID STREET, EDINBURGH ; AND

MURRAY \& SONS, WAVERLEY STATION BOOK-STALL, AND BUCHANAN STREET, GLASGOW. 
t. 



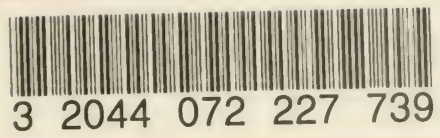

\footnotetext{
6 PNUNA RY क्री
} 
